\title{
Constructivist Approach in Ottoman Mathematics Education: Salih Zeki *
}

\author{
Müjdat Takıcak \\ Kastamonu University, Faculty of Sciences and Arts, Kastamonu/Turkey (ORCID: 0000-0002-7809-5156)
}

Article History: Received: 1 October 2020; Accepted: 27 January 2021; Published online: 5 February 2021

Abstract: In this study, it is aimed to determine whether the mathematics education approach of Salih Zeki, one of the late Ottoman mathematicians, has a constructivist character. For this purpose, 6 geometry textbooks written by Salih Zeki at middle school level were examined. Document analysis method was used in the research. In order to determine whether the textbooks have a constructivist character, 11 criteria have been determined and books have been analyzed based on these criteria. According to the results obtained, 6 geometry textbooks written by Salih Zeki have a constructivist character.

Keywords: Mathematics education, constructivism, Salih Zeki

DOI:10.16949/turkbilmat.803329

Öz: Bu çalışmada son dönem Osmanlı matematikçilerinden Salih Zeki'nin matematik eğitimi yaklaşımının yapılandırmacı karakter taşıyıp taşımadığını tespit etmek amaçlanmıştır. Bu amaç doğrultusunda Salih Zeki’nin ortaokul seviyesinde yazdığı 6 adet geometri ders kitabı incelenmiştir. Araştırmada doküman analizi yöntemi kullanılmıştır. Ders kitaplarının yapılandırmacı karakter taşıyıp taşımadığının tespiti için 11 adet kriter belirlenmiş, bu kriterlere dayanılarak kitaplar analiz edilmiştir. Elde edilen sonuçlara göre, Salih Zeki’nin yazdığı 6 adet geometri ders kitabı yapılandırmacı karakter taşımaktadır.

Anahtar Kelimeler: Matematik eğitimi, yapılandırmacılık, Salih Zeki

Türkçe sürüm için tıklayınız

\section{Introduction}

In mathematics education, the philosophy of mathematics determines how we learn and teach mathematics in the classroom and school environment. If mathematics exists as an ideal waiting to be discovered, as the Platonist tradition asserts, then it will be sufficient for schools to present mathematics as an ordinary body of truths, definitions, and algorithms. From this point of view, mathematics is like conveying a constant fund of knowledge that students have to accept as true without any reasoning. However, if mathematics is a cultural, creative and experimental activity, then the methodology adopted by students will have a tendency to construct their own mathematical knowledge, no matter how different from classical mathematics (Handal, 2009). The appropriate approach for this methodology is constructivism.

Constructivist approach deals with issues such as knowledge, the nature of knowledge, how we know, what kind of process the dissemination of knowledge is and what affects this process, and its notions form the basis of educational practices (Demir \& Şahin, 2009). According to this approach, learning is not a passive utilization of knowledge, but a process in which the structuring of concepts continues actively. In this process, meaning is emphasized, not memorization (Shirtsiz \& Kan, 2007). Constructivists argue that knowledge is structured by the individuals trying to make their own lives meaningful, and knowledge is not passively acquired from the environment. Individuals are not empty barrels waiting to be filled (Koç \& Demirel, 2004). Therefore, constructivism is a cognition-based approach that takes place in the world of the learner with the mental construction process of the individual, and the learner is at the center of the learning process in the construction of knowledge (Brooks \& Brooks, 1999). From another point of view, constructivism is to learn by associating newly-seen knowledge with previous knowledge, thus creating new learning depending on previously-known subjects (Arslan, 2007). In the constructivist learning program, the learning content should not only respond to the interests and needs of the students, but also be original and relevant to real life. In other words, learnercentered design should be applied instead of subject-centered design. Structuring what the learner learns is of utmost importance (Koç \& Demirel, 2004).

There are three basic views on how information is formed in the constructivist approach:

1. Cognative Constructivism

\section{Corresponding Author: Müjdat Takıcak (D) email: mujdattakicak78@gmail.com}

* This publication is based on the author's doctoral thesis titled "Salih Zeki'nin Matematik Felsefesi ve Matematik Eğitimi Anlayışı" [Salih Zeki's Philosophy of Mathematics and Understanding of Mathematics Education], and a part of this publication was presented in the Symposium titled "4. Uluslararası Türk Bilgisayar ve Matematik Eğitimi Sempozyumu” [4th International Symposium of Turkish Computer and Mathematics Education].

Citation Information: Takıcak, M. (2021). Constructivist approach in Ottoman mathematics education: Salih Zeki. Turkish Journal of Computer and Mathematics Education, 12(1), 378-423. http://doi.org/10.16949/turkbilmat.803329 


\section{Social Constructivism}

\section{Radical Constructivism}

In all three of these approaches, knowledge is not passively acquired from outside. The common point in these approaches is that the knowledge is structured in the mind, and the individuals create the knowledge themselves. The preparation of suitable environments for learning is also one of the factors required for individuals to form their knowledge. It can be stated that we learn the following by structuring in our minds: what we have learned, what we learn and what we are going to learn. In other words, we learn by trial and error, discussing, embracing what we think and do, analyzing, doing and living (Delil \& Güleş, 2007).

When constructivism first emerged, it focused on how students learned information. Constructivist understanding, which has developed over time, has begun to question how students construct knowledge (Erdem \& Demirel, 2002).

How can a mathematics education suitable for the constructivism be given? According to Paul Ernest, constructivist mathematicians consider that classical mathematics may not be safe and mathematics needs to be reconstructed by "constructivist" methods. In addition, constructivists claim that it is necessary that both mathematical truths and the existence of mathematical objects be constructed by constructivist methods. This means that mathematical constructions are necessary as opposed to methods based on contradiction and proof to construct truth or existence (Ernest, 2004). This last claim of the constructivists is in parallel with the rejection of the "reduction to absurdity" (reduction ad absurdum) method, one of the mathematical proof methods, by the Intuitionist movement, which emerged under the leadership of Brouwer as a result of the philosophy of mathematics in the 19 th century to rebase mathematics.

Although some constructivists retain the idea that mathematics is the study of constructivist methods set forth with paper and pencil, the harsher intuitive view led by Brouwer claims that mathematics is primarily in the mind, and accumulated mathematics is of secondary importance. In limited areas where there are both classical and constructivist proofs of an outcome, constructivist proofs are preferred due to being more informative. Whereas a classical proof of existence can only show the logical necessity of existence, a constructivist proof of existence shows how a mathematical object that can be claimed to exist can be constructed (Ernest, 2004).

As a result of the crisis in the foundations of mathematics in the early 19th century, the idea of putting mathematics back on solid foundations led to the emergence of three paradigms: Logicism, Formalism, Intuitionism (Handal, 2009). On the other hand, Ernest suggested constructivism as the third paradigm besides logicism and formalism while introducing the aforementioned three paradigms in his book The Philosophy of Mathematics Education. In order to indicate that intuitionism and constructivism have the same meaning, Ernest suggested the constructivism similar to intuitionism (Ernest, 2004). Some philosophers like Ernest can use intuitionism and constructivism interchangeably.

Mathematics education is generally based on 2 basic strategies. The first one is the strategy that emerges in the form of presenting mathematical relations, formulas, and relationships as a whole, without considering the personal characteristics of the individuals to be trained. In this strategy, students are in the position of passive information receivers in educational activities. The second one is that the strategy that in which mathematics is perceived as a whole, and mathematical concepts are associated with each other, formulas, relations and theorems are clarified through the cause and effect relationship, the student is informed about the development process of mathematical knowledge, individuals are active information receivers in the education process, mathematical knowledge is made meaningful, and mathematics is reconstructed in the student's mind. The main features of the second approach - constructivist education approach - can be explained as follows:

- Constructivist approach aims to improve the ability to understand, solve problems and adapt information to new situations. This approach is against the traditionalist and objectivist paradigm that is dominant in education. According to the constructivists, information cannot be passively received through sensory organs and the environment; however, it is effectively structured by the learner. The purpose of constructivist learning is not to help learners reach goals that are predetermined to certain hierarchy but to provide learning opportunities for learners to cognitively make sense of information. Constructivism has been strongly influenced by Piaget and Vygotsky. Deductive and inductive approaches are used in the constructivist education program. Content is structured around basic concepts and principles (Çelik, 2006).

- Constructivist learning is a theory whose roots date back to approximately 100 years although it is thought to be suggested by Piaget (1896 - 1980) (Altun, 2004).

- Constructivism, which is not teaching but a learning theory, is based on the following three assumptions (Delil \& Güleş, 2007):

- Knowledge cannot be built without a personal contribution. 
- Understanding arises as a result of adaptation. Persons harmonize their own experiences and knowledge with the subject discussed, and understands the subject.

- Information arises as a result of interaction. The language in use and the social environment in which persons are involved play an important role in this interaction.

The constructivist approach has been used frequently in mathematics education since the mid-20th century. However, it is probable to find individual examples for the constructivist approach long before. This article attempts to find out whether the late Ottoman mathematician Salih Zeki, has a constructivist approach to mathematics education through the textbooks Zeki wrote.

\subsection{Salih Zeki}

Salih Zeki, one of the important scientists who lived in the last period of the Ottoman Empire, was born in Istanbul, in 1864. Salih Zeki, one of the first graduates of Darüşşafaka, started working at the Ministry of Post. He was sent to Paris by the institution he worked for in a short time to study telegraph engineering. During two years in Paris, he was interested in mathematics as well as engineering. He took lessons from Henri Poincaré, one of the important figures in the history of mathematics and adopted his opinions about science and philosophy. After completing his education, he took senior positions at various levels of the state institutions. $\mathrm{He}$ personally participated in astronomical observations during the directorate of the Rasathane-i Amire [State Observatory]. Starting from 1900, he started to give lectures in the Department of Mathematics at Dârü'l-Fünûn ["University" in Ottoman Turkish]. Between 1913 and 1917, he served as the General Directorate of Dârü'lFünûn [Rectorate]. He continued to teach in the Department of Mathematics until his death in 1921.

Many biography studies have been carried out on Salih Zeki, who undertook very important duties in the last period of the Ottoman Empire. In addition, reviews on Salih Zeki's books and articles were written by various authors. Unlike the others, this article highlights Salih Zeki's identity as an instructor of mathematics. In this study, six geometry textbooks written by Salih Zeki between 1907 and 1915 were evaluated in terms of the constructivist approach, which is accepted as one of the effective teaching strategies in the 20th and 21st centuries by today's instructors of mathematics. In addition to Salih Zeki's identity as a pure mathematician and philosopher of mathematics, this study searches in his textbooks for the traces of Zeki's identity as an instructor of mathematics. Therefore, the emphasis is on how Zeki teaches rather than what he teaches.

1. Hendese-i Tecrubiyye [Applied Geometry]: Salih Zeki wrote this book on the request of the Ministry of Education to be taught in 3rd grade of all secondary schools. The book covers the topics of point, line, plane, length, area and volume (The first edition of this book is of 1892. 1909 edition is used in this publication).

2. İlk Hendese Dersleri, Devre-i Âliye Birinci Sene, Üçüncü Kitap [First Geometry Lessons, First Grade of Secondary School, Third Book]: It was written by Salih Zeki and Hamazasb Hâki in 1915, at the request of the Ministry of Education, to be taught in the first grade of the Mekteb-i İbtidâiye [secondary school]. The book covers subjects such as angle, properties of angle, construction of angles, geometric tools, position and construction of lines relative to each other, basic geometric shapes and properties.

3. İlk Hendese Dersleri, Devre-i Âliye İkinci Sene, Dördüncü Kitap [First Geometry Lessons, Second Grade of Secondary School, Fourth Book]: It was written by Salih Zeki and Hamazasb Hâki in 1915, at the request of the Ministry of Education to be taught in the second grade of the Mekteb-i İbtidâiye. The book includes topics such as the properties of the circle, straight and curved lines, straight and curved surfaces, cylinders and cones. In addition, the geometrical infrastructure and usage instructions of the instruments to be used in land measurement are also explained in the book.

4. Ilk Hendese Dersleri, Birinci Sene [First Geometry Lessons, First Year]: It was written by Salih Zeki in 1914, at the request of the Ministry of Education to be taught in the third grade (secondary school 3) of the Mekteb-i İbtidâiye. The book consists of three chapters: The first one includes definitions; the second one plane shapes and their properties, and the third one drawings and construction of the geometric shapes.

5. İlk Hendese Dersleri, İkinci Sene, Devre-i Mutavassıta, İkinci Kitap [First Geometry Lessons, Fourth Grade of Secondary School, Second Book]: It was written by Salih Zeki in 1914 at the request of the Ministry of Education to be taught in the fourth grade of the Mekteb-i İbtidâiye. The book consists of three chapters and the following subjects are covered respectively: area calculation, volume calculation, geometric solutions to daily life problems.

6. Nazarî and 'Amelî Mücmel Hendese [Theoretical and Applied Geometry]: It was written by Salih Zeki in 1911 for the purpose of facilitating the education of middle school students who learned only applied geometry to learn theoretical geometry. The book includes lines, angles, plane shapes, area volume calculation and applications. 
Changes have been made in mathematics education in order to teach mathematics to students in a better way for about 100-150 years. Most of these changes have been specific to the curriculum. However, it is obvious that improvement could not be made at the desired level. It would be useful to analyze the mathematics education carried out in the last period of the Ottoman Empire and the Early Republican period, rather than focusing only on what has been done or not done today in order to determine the source of the problem. There are not many researches on this subject in Turkey. This study aims to identify whether the textbooks of Salih Zeki, one of the Late-Ottoman mathematicians, had a constructivist character.

\section{Method}

Historical researches are generally carried out using written texts in archives. Document analysis, which is a method frequently used in researches on written texts, is also the method of this research. Document review covers the analysis of written materials that contain information about the phenomenon or facts to be investigated. Document review for a qualitative research can be used as a data collection method alone (Yildırım \& Şimşek, 2011).

Constructivism is an educational strategy that requires the school, students and teachers to work in harmony in the education-training environment. To be able to apply the constructivist learning approach, each of these three elements is crucial. This study aims at determining whether the textbooks of Salih Zeki were written in accordance with the constructivist approach. On the basis of the basic features of constructivism, basic criteria are necessary to determine whether a textbook has a constructivist approach. 11 criteria are established following literature review and applying for expert opinions, and these criteria are as follows:

1. Is the student directed to meaningful learning through constructing knowledge in the student's mind? (MEB, 2009b; Özgen \& Alkan, 2012)

2. Has any association been formed between mathematical concepts? (MEB, 2009a; MEB, 2009b; MEB, 2013)

3. Has previous knowledge been activated and associated with new information? (Bukova-Güzel, 2008; MEB, 2009b )

4. Are mathematical concepts included in the book in a way that they create mathematical meanings from students' concrete experiences and intuitions? (MEB, 2009a; MEB, 2013)

5. Is there a problem solving method in the book? (Özgen \& Alkan, 2012)

6. Are there any associations between subjects of mathematics and real life? (Arkün \& Aşkar, 2010; Bukova-Güzel, 2008; MEB, 2009b; MEB, 2013)

7. Does the book provide the student with the necessary material and cognitive context in order to construct knowledge? (Baki, 2006; Delil \& Güleş, 2007; MEB, 2009b ; MEB, 2013)

8. Are there any activities that will give students high-level thinking skills?

9. Has a relationship been established with other disciplines? (MEB, 2009b)

10. Are there any multiple display tools such as graphics, pictures and figures in the content? (Baki, 2006; Özgen \& Alkan, 2012)

11. Are the practice problems of questions on the subject organized to improve students' reasoning skills?

The fact that the abovementioned criteria are established following literature review has increased the reliability of the study. In order to ensure external validity, direct citations were taken from the textbooks.

This study quests for the traces of constructivist method in Salih Zeki's textbooks by analyzing data within the context of the abovementioned criteria through document analysis method, and it provides information about the existence of these criteria in Zeki's textbooks and to what extent they have a constructivist approach. Textbooks were transliterated from Ottoman Turkish (from Arabic letters to Latin letters) by the researcher.

\section{Findings}

In this part of the study, the findings obtained from 6 geometry textbooks analyzed within the framework of the abovementioned criteria will be shown. At the introduction of the textbook titled Ilk Hendese Dersleri Birinci Sene [First Geometry Lessons First Year], Salih Zeki wrote a foreword addressing teachers to give the course. In his foreword called "Warning to Teachers", Zeki specifies the methods and strategies to be used in the teaching of the course: 


\section{Warning to Teachers}

This book will be in the hands of children who are beginners for geometry. Teachers should not make children memorize the subjects but they should explain them to children. The subjects of the first chapter will be explained to children gradually in the classroom, in the garden, briefly everywhere, and the related activities of the second chapter will be done right after. Teachers should not attempt to teach geometry unless there are a few rulers and compasses, even a chalk, a wooden compass and a sufficient number of pencils, a few miter, at least one protractor at school where children are present. Teachers should not make children memorize descriptions. On the contrary, teachers should make students draw shapes, make descriptions and find solutions (Zeki, 1332/1914a, p.2).

The fact that Salih Zeki made recommendations for teaching geometry in the foreword of his book shows that he is not only a mathematician but also an educator. In the first paragraph of his foreword, he wanted students not to memorize any information; however, he urged teachers to create educational environments that would enable students to construct knowledge. In the second paragraph, he stated that teachers should not make students memorize any definitions or rules, but urge them to find definitions or rules by making them draw some shapes. In this sense, it can be said that Salih Zeki attempted at applying the method known as the strategy of learning through discovery in the mathematics education for the students of that period. He also stated that there should be some tools and equipment necessary for teaching mathematics in schools. Salih Zeki's foreword for mathematics teachers shows that the author consciously chooses methods and techniques used in mathematics education.

Six geometry textbooks of Salih Zeki were examined within the framework of 11 criteria determined for the research.

\subsection{Examples of Constructivist Character in Textbooks}

\subsubsection{Is the student directed to meaningful learning through constructing knowledge in student's mind?}

In this section, it is analyzed whether the narration in 6 geometry textbooks written by Salih Zeki, is suitable for the construction of knowledge in student's mind as the first criterion. For example, Salih Zeki started his book Hendese-i Tecrubiyye with " ta'rifât ", which means definitions:

There are 3 kinds of things that can be measured. These are length, area and volume. For example, 'How many meters is it from one end of this class to the other?' If such a question is posed, the aim is to measure length. 'How many square marbles of 1 meter per side can be laid on the floor of this classroom?' If such a question is posed, the aim is to measure area. 'How many cubes of 1 meter on one side will fit in this classroom?' If such a question is asked, the aim is to measure the volume (Zeki, 1327/1909, p. 3-4).

The author attempted to construct the definitions with cases, not just with the theoretical information on the book. The aim is to make the student absorb the definitions. In a book that the construction of a concept for area and volume is disregarded, there are theoretical explanations such as "The area of a rectangle is given by multiplying the width times the height... The volume of a rectangular equals the product of its base area and its height. Volume $=$ Area of base $\times$ height" and so on. However, the cases provided in the book Hendese$i$ Tecrubiyye on the subject of area and volume aim to reach the mathematical "real meaning" of these concepts. It can be said that an approach attempting to explain the essence of the concept, away from formulas and rules, has been adopted. "How many square marbles of 1 meter per side can be laid on the floor of this classroom?" It expresses an important example that will lead the question to the concept of area. Similar approaches have been adopted for other concepts in the section of definitions. For example;

Area is the surface of anything. [...] There are three types of areas. There are some areas in which a ruler touches that area at every point, such as the surface of a table. These areas are called smooth areas. [...] There are some areas where a ruler touches it in one direction and only at one point in the other direction, such as the lateral area of a water pipe. These areas are called curved areas. [...] There are some areas where a ruler touches only at one point in all directions, such as a surface area of an egg. These areas are called round areas (Zeki, 1327/1909, p. 6-7).

We can consider this point in the section of definitions as the first sign of the constructivist approach in terms of constructing concepts. In this part of the book, Salih Zeki constructs the concepts of length, area, volume, length types, area types, and volume types. 
In the second chapter of the book Hendese-i Tecrubiyye, the topics of length and length measurement, main features of which are given in the first lesson, are discussed in more detail. The length measurement is explained as follows:

Measuring the length of something means to find out how many of something else known to everyone are in that thing. What is well known is called the comparison unit or unit. For example, measuring the length of this class means to find out how many of this length we call meters are (Zeki, 1327/1909, p.13).

In this sentence, the question of "how many of something known to everyone are in that thing" takes us back to the origin of the concept of unit. It is expressed that in order to make any measurement, there must be something that can be compared. In this way, the student can grasp that length measurement units such as kilometers, meters, centimeters are not absolute measurement units, but they are a universal length assumption, and length measurement units can be created apart from all these units. This intellectual ground will be the base for the area and volume calculations to be explained later in time.

Salih Zeki explained the definitions and concepts in his other books in a way that adheres to this approach. For example, Zeki made the following explanation about iso-surfaces in his book, in his book $\dot{I} l k$ Hendese Dersleri, Devre-i Âliye Ikinci Sene:

If each point of a surface is completely coincident to each point of the other surface, these surfaces are called as mating surfaces (Zeki \& Hâki, 1332/1914, p. 4).

Salih Zeki, in his book Hendese-i Tecrubiyye, gave the definitions of rectangular and square and continued the construction activity, without going into the subject of area:

If we take a simple piece of paper, we will see that the angles on its four corners are right angles. Moreover, we know by experience that all four sides of the paper are equal and that two are large and the other two are small. However, as the larger ones are equal to each other, the smaller sides are also equal to each other. In order to understand this, if we bend the paper once wide and once across, it turns out that the big edges are equal in the first and the small edges in the second. The four-sided shape whose four angles are right angles and whose sides are equal to each other, just like a simple paper, is called a rectangle in geometry. Now let's bend that piece of paper diagonally so that the larger edge is on top of one of the smaller edges. In this case, a piece of excess is formed in the size of the paper. If we remove this excess with a pair of scissors and open the paper back on the table, this time a shape with perpendicular angles and equal quadrants is formed. A shape whose four sides are equal to each other and whose angles are right angles is called a square in geometry, as in this figure. The area of a square whose length is equal to 1 meter on each side is measured in the form of one square meter (Zeki, 1327/1909, p. 48-50).

Definitions of rectangle and square were based on an A4 paper we use in daily life. The definition made on the basis of a familiar example makes it easier to create a new concept in mind. Defining a square based on a rectangle makes you feel that each square is also a rectangle. The definition of unit square in the same paragraph shows that the construction activity continues in terms of forming the basis for the area concept to be explained later. Structuralism (Baki, 2006), which is used to create a structure by bringing parts together, finds its correspondence in this section of the book.

In the behavioral approach, conversions between units of measure (e.g. 1 square meters = 100 square decimeters $=1000$ square centimeters...) are itemized in a table. These conversions are explained in the book Hendese-i Tecrubiyye in the following way:

[...] Now, let's draw a square with a side of 1 meter on the blackboard. Let's divide each side of this square into ten equal parts. Then, let's connect the opposite points with line segments. In this case, we divide the square we have drawn on the board into some small squares. The sides of each of these squares are equal to 1 decimeter. Such squares with sides equal to 1 decimeter are called square decimeters. I wonder how many decimeters there are in the square meter we drew on the board before? To find this, let's first count how many small squares are aligned with one side of the bigger square: we find that there are ten square decimeters. We understand from this that there are ten rows on top of each other inside the big square, and each row has ten small squares. So there must be $10 \times 10=100$ squares in the whole square. This means that in 1 square meter, that is, a square with a side of 1 meter or 10 decimeters, there are 100 square decimeters (Zeki, 1327/1909, p.50-51).

The measurement for area that is taught by heart information is expressed here by modeling in the behavioral method. The same model was repeated for square centimeters and square millimeters in the later chapters of the book, allowing for the integration of area measurement units in students' minds. In addition, the question in the 
paragraph above "I wonder how many decimeters there are in the square meter we drew on wood before?" also makes one feel how to find the surface area in geometric shapes. In this respect, we see that the construction activity continues for the next chapter. The following sentence in this section of the book Hendese-i Tecrubiyye [Applied Geometry] explains the concept of area:

Measuring an area means to find how many square meters or how many square decimeters or how many square centimeters there are in that area (Zeki, 1327/1909, p. 52).

Another definition of the concept area concept is explained in the book Ilk Hendese Dersleri, Birinci Sene in the following way:

To measure an area means to find how many units of measurement there are in this specific area.

The generally accepted unit of measurement for areas is the area of a square of one meter in width and length, which is called square meter. [...] It can be said how many square meters an area can contain is that much square meters (Zeki \& Hâkî, 1334/1915, p. 65).

Constructivismexplains how an individual reaches information, develops and uses these processes (Gömleksiz \& Kan, 2007). The concept of area in the book Ilk Hendese Dersleri [First Geometry Lessons], as previously in the book Hendese-i Tecrubiyye, is defined as "to measure an area means to find how many units of measurement there are in this specific area.", and all the area calculations have been built on this concept.

The concept of area, which is formed in a single sentence in the book Hendese-i Tecrubiyye, is first constructed and then formulated. Then, the following explanation about the area is given:

If we take a set of one-centimeter-wide and two-centimeter-long dominoes, and divide them in half, we get many squares with each side of 1 centimeter. Each of these squares is 1 square centimeter as we saw in previous lessons. Let's take four of these small squares and arrange them one after another. In this case, we get a rectangle, the area of which is equal to the sum of 4 square centimeters. Since there is only one row, and there are four square centimeters in it, there is no doubt that the sum is $1 \times 4=4$ square centimeters. Now let's add a second row by placing four more half dominoes under this row. The resulting shape will become a rectangle, as well. But since there are 2 rows in this rectangle and each row has 4 square centimeters, its area is only $2 \times 4=8$ square centimeters. [...] It can be seen in the following examples that in order to measure the area of a rectangle, it is necessary to find out how many square centimeters it equals and to look for how many centimeters there are on the big and small sides, and then to multiply these two numbers. What we do to find the area of a rectangle is called to multiply the width of the rectangle by its length. The purpose of this is to measure the width and length separately and multiply those numbers with each other. The result obtained in this way shows how many square centimeters there are in that rectangle (Zeki, 1327/1909, p. 52-53).

In this paragraph explaining how to calculate the area of a rectangle, it can see that the inductive method is adopted by creating large rectangles from small squares. The concept of area is constructed step by step in students' minds, which is a suitable method for its essence.

The circumference and area of the circle is one of the most difficult subjects for students to learn. Most students hear about $\pi$ for the first time in their lives thanks to this subject. If $\pi=3,1416$ is said to be a constant number used in calculating the circumference and the area of the circle, students will not be able to do anything but use this information in practice-level questions by writing the relevant numbers instead of the formula. On the other hand, Salih Zeki explains the relationship between the number and the circumference of the circle in his book Illk Hendese Dersleri, Devre-i Âliye Ikinci Sene:

[...] The straightest line of curved lines is the circumference of the circle. [...] As a result of some calculations and many exercises, it has been found that each circumference of circle is 3.1416 times bigger than its own diameter. So, to understand how long the circumference of a circle is, the diameter of that circle must first be measured, then the value must be multiplied by the number 3,1416 . This amount is fixed. It is denoted by the Greek letter $\pi$ and pronounced as pi. That is why the circumference of a circle = diameter $x \pi$ (Zeki \& Hâki, 1332/1914, p. 12).

The paragraph above, which explains what the number $\pi$ means and where it comes from, has enabled the relationship between the circumference of the circle and the nature of the number $\pi$ to be revealed and the circumference of the circle to be constructed in student's mind as a part of meaningful learning. In addition, in the book Ilk Hendese Dersleri, Devre-i Mutavassita Ikinci Kitap, the number $\pi$ is handled with a similar approach as follows: 
Circumference of circle: To find out how long a circle is, that is the distance around the circular region, multiply its diameter by the number 3,1416 . The number 3,1416 is the ratio of the circumference of a circle to its diameter. This number is constant for all circles, and it does not change. [...] For example, if the circumference of a round tree was 2,40 meters, what would its diameter be? To find the diameter of a tree, we divide the circumference we measured with the string by the number 3,1416 . We find $\frac{2,40}{3,1416}=0,76$ meters (Zeki, $1332 / 1914$ b, p. 10).

Salih Zeki, who continues his constructivist method just as in the calculation of area, defines the volume concept in his book named Illk Hendese Dersleri, Devre-i Âliye İkinci Sene as follows:

To measure the volume of any object means to search and find out how many times the volume, which is accepted as a unit [for the purpose of comparison], is found in that object. [...] The unit for volume is cubic meters (Zeki \& Hâki, 1332/1914, p. 32).

The constructivist method used for the subject area in Ilk Hendese Dersleri [First Geometry Lessons], is also designed for the volumes of geometric objects in accordance with the general definition of volume stated above. For example, the volume of a rectangular prism is described as follows:

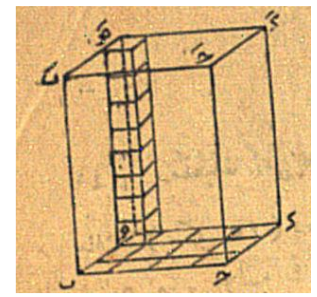

Figure 1

The volume of a rectangular prism is equal to its three lengths [width, height, height] times each other. For example, the length of the base of the rectangular prism shown in Figure 1 is $B C$, its width is $H E$ and the height of this prism is $C C^{\prime}$. In this case, its volume is $C C^{l} \times B C \times H E$. For example, if the base length $B C=4$ metre, width $H E=3$ metre, height $C C^{l}=8$, the volume of the prism would be $4 \times 3 \times 8=96$ cubic meters. [This situation can be proved as follows] The base of this rectangular prism is equal to $4 \times 3=12$ square meters. Now, if one cubic meter is placed on each of 12 square meters, a layer of one meter high, that is, a layer of rectangular prism, is created. In other words, there are 12 cubes on this floor with a floor area of 12 square meters and a height of 1 meter. However, since the height of this rectangular prism is 8 meters, 7 more such layers can be stacked on this layer. Since all rectangular prisms can be equal to 8 such layers and there will be $4 \times 3=12$ square meters in each layer, the total number of cubes becomes $4 \times 3 \times$ $8=96 \ldots$ In this case, the volume of a rectangular prism is equal to the product of its base area and its height (Zeki \& Hâki, 1332/1914, pp. 32-33).

Salih Zeki prevented the mental clamp that could be formed on students by a pure mathematical formula and enabled the concept of volume to be formed in their mind. For this purpose, the author supported the subject with visual elements. However, in a textbook that does not have the idea of "the construction of mathematics in mind", this subject will be limited only to the definition of "the volume of a rectangular prism is equal to the product of its base area and its height".

Salih Zeki has constructed the proposition "a steep line can be drawn through the point on a line" in his book Nazarî ve 'Amelî Mücmel Hendese as follows:

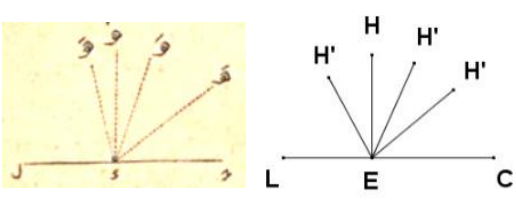

Figure 2

For example, (Figure 2) only one perpendicular like $E H$ can be drawn from the point $E$ of the line $L C$ to this line. Because let's assume the line $E C$ coincides with the line $E C$ first and rotate it from right to left around the point $E$. As this rotation is continued, the angle formed on the right side will always increase and the angle formed on the left side will also decrease. Here the line $E H^{\prime}$ 
rotated around the point $E$ precisely, comes to the condition of $E H$ in that condition in which left and right angles on both sides will be equal to each other. The line $E H$ has a rather steep towards the line $L C$. Regardless of what happens in this situation, if there is a small movement, the equality between the angles formed on both sides will be broken, so the line $E H^{\prime}$ cannot be vertical to the line $L C$. It is understood from this that only one perpendicular $E H$ can be drawn to this line from a point $E$ of the line $L C$. However, it cannot be drawn more than one (Zeki, 1322/1904, p. 1718).

The explanation given for the proposition that only one line can be drawn perpendicular to a straight line at any given point on that line is such that students can form this proposition in their minds. Thus, this attempted to create a meaningful learning environment by explaining a rule that can be given in a single sentence step by step in detail.

Salih Zeki expressed the angle value in terms of "right angle" instead of giving it in "degree". This will allow students who are new to geometry to have the concept of angle embedded in their minds regardless of degree. Otherwise, the student may the mistake of expressing the right angle with only 90 degrees (Zeki, 1322/1904, p. 19-21).

\subsubsection{Has any association been formed between mathematical concepts?}

The world of mathematics will be much more understandable when mathematical concepts are associated with each other. In this section, it was examined whether there is a relationship between mathematical concepts in 6 textbooks written by Salih Zeki.

After explaining the area of rectangle, square and parallelogram in a chronological order in Salih Zeki 's textbook titled Ilk Hendese Dersleri, Devre-i Âliye İkinci Sene, the next topic is the area of triangle. In a classic textbook prepared with a behavioral strategy does not have this chronological order of subject. Parallel to the number of sides, the area of triangle is described first and then the area of rectangle and later square, and only following these descriptions, areas of relatively more specialized shapes such as parallelogram, rhombus and trapezoid are explained. In this book, the area of rectangle, square, and parallelogram is explained by associating them with the area of triangle as follows:

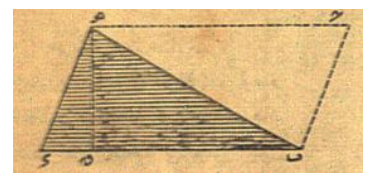

Figure 3

The area of a triangle is equal to half of the product of its base and height. [The proof of this rule can be done as follows] As can be seen from Figure 3, the triangle $B H E$ is exactly half of the parallelogram $B C H E$. The area of parallelogram $B C H E$ is equal to the product of the base $B E$ and the height $H G$. Therefore, the area of triangle $B H E$, which is equal to half of this parallelogram, must be equal to half of the product $|B E| x|H G|$ obtained before (Zeki \& Hâki, 1332/1914, p. 78).

Finding how to calculate the area of triangle means that the areas of all shapes whose area can be divided into triangles can also be calculated. As a matter of fact, the first example of this appears in the area of trapezoid:

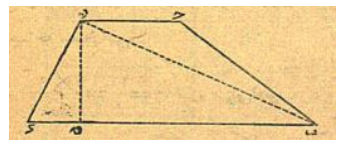

Figure 4

The area of trapezoid is equal to the average of the bases multiplied by the altitude. By dividing the trapezoid $B C H E$ with the diagonal $H B$ to triangles $B C H$ and BHE, we can see that it would equal the sum of the areas of two triangles, which proves the accuracy of the method above (Zeki \& Hâki, 1332/1914, pp. 8-9).

Another figure whose area is calculated using the area of triangle is a regular polygon. Regular polygons can be divided into equilateral triangles and their areas can be calculated. The conceptual relation of mathematical figures to the area is also valid about the area of the regular polygon: 


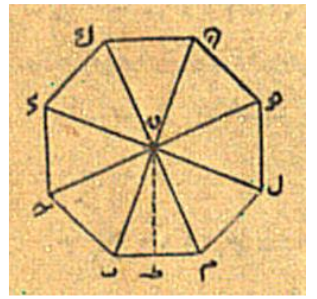

Figure 5

The area of a regular polygon is equal to half the product of the perimeter and height. [...] [This base is proved as follows] If we draw all the radius triangles of this figure MLHNKECB (an eightsided regular polygon as shown in the figure), eight identical isosceles triangles will be formed (Figure 5). One of them is the area of the triangle $F M B$, for example $\frac{|M B| x|F T|}{2}$, that is $\frac{2 x 3}{2}=3$ square meters. Since this regular shape consists of eight triangles like this, the area of the polygon becomes $8 \times 3=24$ square meters (Zeki and Hâki, 1332/1914, p.11-12).

The area of the triangle is associated with the area of the regular polygon so that there is no gap in students' minds regarding the concept of area. Therefore, it is seen that the cognitive environment necessary for students to form the area knowledge of planar shapes is provided. The last shape described by relating its area to the area of triangle is a circle.

Salih Zeki explained the concepts of polygon, circle, circumference and number $\pi$ by forming associations between these terms in his book Nazarî and 'Amelî Mücmel Hendese. Salih Zeki explained the relation of circumference of the circle and the area of the circle, which are not easy to understand for students, by proving them in suitable way for their levels. Salih Zeki explained how the constant value $\pi$ used in these relations is formed by using the principle of induction as follows:
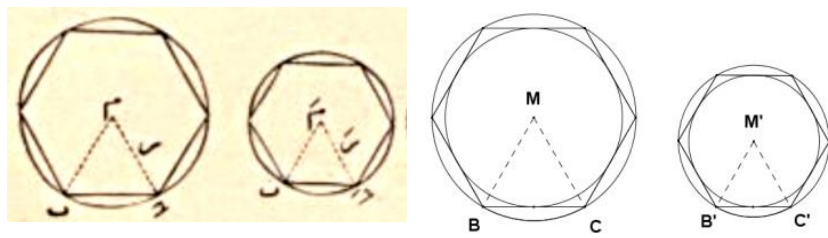

Figure 6

The ratio between the circumference of two regular polygons with the same number of sides is equal to the ratio between radii of their circumferential circles. For example, a regular hexagon is drawn inside the circles $M, M^{\prime}$ (Figure 6 ). The sum of the sides of these two regular hexagons is $\frac{t}{t^{\prime}}=\frac{r}{r^{\prime}}$ their circumference is expressed as $t, t^{\prime}$ and the radii of the circles as $r, r^{\prime}$. These two polygons are similar [according to the proven theorem] because they have the same number of sides. For this reason, the ratio between their circumferences [according to the theorem proved] is equal to the ratio between their edges. In other words, it is equal to $\frac{t}{t^{\prime}}=\frac{B C}{B^{\prime} C^{\prime}}$. However, if line segments are drawn between and $M$ and $B, C$ and $M^{\prime}$ and $B^{\prime}, C^{\prime}$ points, two triangles such as $M B C$ and $M^{\prime} B^{\prime} C^{\prime}$ are formed, which are similar to each other. Now it is found out of their similarity $\frac{B C}{B^{\prime} C^{\prime}}=\frac{B M}{B^{\prime} M^{\prime}}$ or $\frac{B C}{B^{\prime} C^{\prime}}=\frac{r}{r^{\prime}}$. If this ratio is substituted in the above proportion, $\frac{t}{t^{\prime}}=\frac{r}{r^{\prime}}$ will be obtained (Zeki, 1322/1904, p. 143-144).

After proving that the ratio between the circumferences of two regular hexagons is equal to the ratio between the radii of the circumferential circle of this hexagon, Salih Zeki explained that the same proportion can be considered for circles, which he thinks of as an infinite sided polygon:
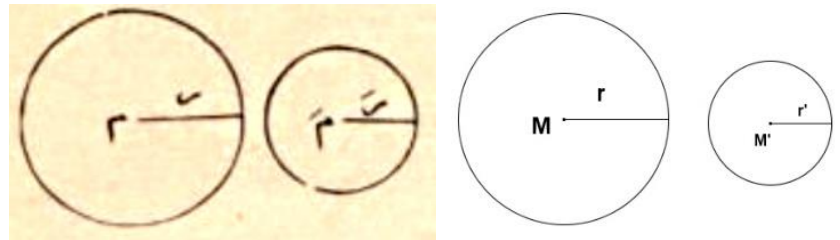

Figure 7 
The ratio between the circumferences of two circles is equal to the ratio between their diameters. For example, if circumference of the circles $M, M^{\prime}$ are $t, t^{\prime}$ and their diameters are $R, R^{\prime}$ (Figure 7), it is $\frac{t}{t^{\prime}}=\frac{r}{r^{\prime}}$. Because both circles are accepted as two similar regular polygons with infinite number of sides, the ratio between their circumferences is equal to the ratio between their radii $r, r^{\prime}$ as per the previous theorem. In other words, it is $\frac{t}{t^{\prime}}=\frac{r}{r^{\prime}}$. Now, when the variables of the second ratio are multiplied by 2 , it is $\frac{t}{t^{\prime}}=\frac{2 r}{2 r^{\prime}}=\frac{R}{R^{\prime}}$, Which also proves the theorem (Zeki, 1322/1904, p. 144-145).

Salih Zeki continued his constructivist method, which he started with a regular hexagon, with the circle he defined as an infinite-sided polygon. He proved by this theorem that the ratio of the circumferences of two circles is equal to the ratio between their diameters. He reached the number $\pi$ by using this proportion:

The ratio of the circumference of each circle to its diameter is equal to a fixed number. For example, circumference of the circles $M, M^{\prime}$ are $t, t^{\prime}$ and their diameters are $R, R^{\prime}$ (Figure 7). As per the previous theorem, their circumference is proportional to their diameter and it is $\frac{R}{R^{\prime}}=\frac{t}{t^{\prime}}$. If the places of the middle proportions change, it is $\frac{t^{\prime}}{R^{\prime}}=\frac{t}{R}$. This equation states that the ratio of the circumference of the first circle to its own diameter is equal to the ratio of the circumference of the second circle to its diameter, so the ratio of the circumference of each circle to its diameter is constant. This constant ratio, the ratio between the circumference and the diameter of a circle, is approximately equal to 3,1416 . This ratio is usually pronounced $p i$, denoted by the letter $\pi$ in the Greek alphabet. Here it is expressed as a constant ratio between the circumference and diameter of any circle, that is $\frac{t}{R}=\pi$ (Zeki, 1322/1904, p. 145-146).

The number $\pi$ is not an expression that most students can easily learn. Explaining how an infinite number of $3,1416 \ldots$ came into being would also mean clarifying the basic point on which the concepts of circle and circle are constructed. Expressing the relations about the circumference of the circle and the area of the circle after obtaining the number $\pi$ will facilitate the absorption of the subject by the students. As a matter of fact, Salih Zeki obtained the correlation regarding the circumference of the circle in a suitable way for the level of the students:

"The previous proportion $\frac{t}{R}=\pi$ creates the equations $t=R \times \pi$ or $=\frac{t}{\pi}$. If two times of its radius,

$2 \mathrm{r}$ is written instead of its diameter $\mathrm{R}$, it becomes $t=2 \pi r$ and $r=\frac{t}{2 \pi}$ (Zeki, 1322/1904, p. 146147)."

Salih Zeki explained the relation related to the circumference of the circle by associating it with other concepts of mathematics at a level that can be constructed in students' minds. He made the students reflect on the number $\pi$ and explained where it emerged from by associating it with the polygon issue.

\subsubsection{Is old information activated and associated with new information?}

In mathematics education, if old subjects and new subjects are explained with associations, mathematics can be constructed as a whole in students' minds. In this section, it will be analyzed whether old topics and new topics are explained in relation to the 6 textbooks of Salih Zeki .

Salih Zeki explained the volume calculation of the cylinder in the textbook titled Ilk Hendese Dersleri, Devre-i Âliye Ikinci Sene, by using the volume calculation of the prism that the student had previously learned:

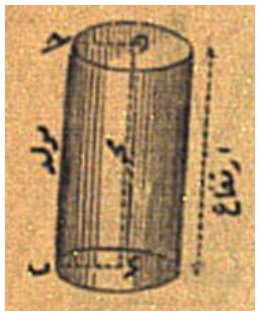

Figure 8

The volume of a cylinder is equal to the product of base area and its height. [This rule is explained as follows:] For example, the cylinder in Figure 8 has the volume as base area $x$ height. In fact; the cylinder can be described as a very narrow prism with very many surfaces. The volume of the prism is equal to the product of base area and its height. Therefore, the volume of the cylinder; 


$$
\begin{aligned}
& \text { The volume of cylinder }=\text { Base area } \times \text { Height } \\
& =\pi \times(\text { Radius })^{2} \times H e i g h t
\end{aligned}
$$

(Zeki \& Hâki, 1332/1914, pp. 44-45).

In addition, Salih Zeki, in his book Nazarî and 'Amelî Mücmel Hendese, explained the sum of the interior angles of the polygons in association with the angle in the triangle mentioned in the book as follows:

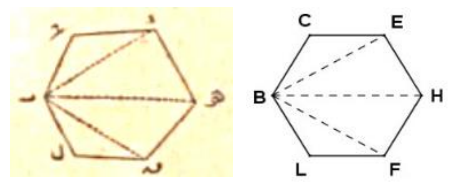

Figure 9

The sum of the interior angles of a polygon is equal to two right angles minus two less than the number of sides of that polygon. For example, even though the polygon BCEHFL has six sided, the sum of its angles $B, C, E, H, F, L$ is equal to $6-2=4$ times two right angles (Figure 9 ). Let's connect any corner of the polygon, for example the corner $B$, with the other corners of the polygon. In this case, since there will always be two adjacent vertices to a corner, the polygon can be divided into triangles with two minus the number of sides. The polygon $B C E H F L$ is divided into four triangles like $B C F, B E H, B H F, B F L$. Now, since the sum of the angles of these triangles will be equal to the sum of the interior angles of the polygon, since the sum of three angles of a triangle is equal to two right angles, the sum of the interior angles of the polygon in question is equal to $6-2=4$, that is, two times less than the number of sides. Here, if the number of sides of a polygon is denoted by the letter $n$, since the number of triangles to be formed in it will be $n-2$, the sum of angles will be $(n-2) \times 2$ right angles (Zeki, 1322/1904, p. 51-52).

Salih Zeki's use of triangles to explain how to find the sum of interior angles of polygons revealed the hidden relationship between these two issues. Student will be able to calculate the sum of the interior angles of a polygon regardless of the number of sides, without any rule. Salih Zeki describes almost every new mathematical knowledge by associating it with other mathematical knowledge. With this method, the student can comprehend mathematics as a whole. After explaining the subject, Salih Zeki did abstracted the new knowlege and did not neglect to formulate it this way.

Salih Zeki discussed the pyramid body after prisms in his book Nazarî 'Amelî Mücmel Hendese. First of all, he expressed the basic features of the pyramid. Since the surface shapes are polygons, the surface area relation of the pyramid has been established by associating it with the area relation described earlier. He explained the volume of the pyramid by relating it to the volume relation of the prism as follows:
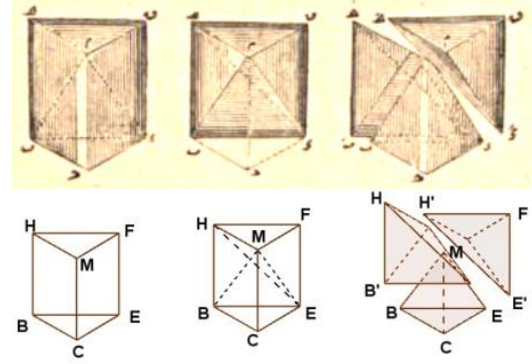

Figure 10

Each triangular prism can be divided into three triangular pyramids of the same base and height, one of which is identical to the other. For example, suppose a triangular right prism like BCEHMN (Figure 10). Let's cut this prism with a plane passing through the $M B E$ points. With this plane, a triangular pyramid like $M B C E$ is separated from the prism. Now, the $M H E$ plane and the remaining part of the prism are divided into two triangular pyramids such as $M B E H$ and $M E H F$ (Figure 10). Now these three pyramids are identical. Let's take the $M B C E, M E H F$ pyramids before: The base of each of them is one of the bases of the prism, and its height is only the height of the prism. On the other hand, $M E H F, M B E H$ pyramids are also identical to each other. Since the bases of these are $E H F, E H B$ triangles and these triangles are only half of the $B E F H$ parallelogram, they are equal to each other. As for their height, it is also common as it is equal to 
the distance of point $M$ to the parallelogram $B E F H$. These three pyramids are identical because they have the same base and height. It follows from this that: A triangular pyramid is equal to one third of a triangular prism with the same base and height. [Hence] The volume of a pyramid is equal to one-third multiplied by the area of the base multiplied by the height (Zeki, 1322/1904, p 202-203).

While the surface area relation of the pyramid is an understandable relation at a glance, the relation of the volume of the pyramid is not a relation that can be understood at once. While the volume of the prism is found by the base area $\times$ height relation; questions such as why the pyramid is $\frac{1}{3} \times$ base area $\times$ height in the volume relation, and where the $\frac{1}{3}$ coefficient comes from are questions that confuse the student. Salih Zeki says that in order to avoid this confusion, a prism can be divided into three identical pyramids by establishing a relationship between the prism and the pyramid; he hence showed that one-third of the volume of the prism would be equal to the volume of a pyramid of the same base and height. Therefore, students can easily grasp the volume of the pyramid.

In Salih Zeki's book Hendese-I Tecrubiyye, the properties of the parallelogram are deduced by establishing a relationship between the properties of square, rectangle and parallelogram . The established relationship is also valid for the calculation of area:
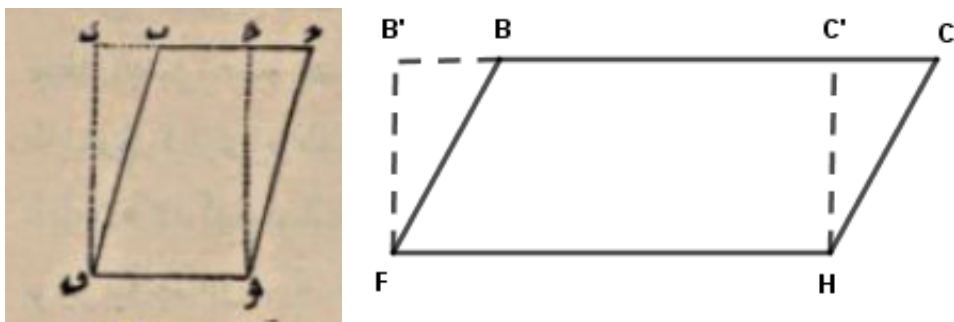

Figure 11

Now that we know what a parallelogram is, let's get to how its area is measured. If we draw a $B C H F$ parallelogram on an $\mathrm{A} 4$ paper and bend the paper twice at points $\mathrm{F}$ and $\mathrm{H}$ so that the line $C B$ is on itself as shown in the figure, we get two bending lines like $F B^{\prime}, H C^{\prime}$. These $F B^{\prime} H C^{\prime}$ bending lines are subject to the fact that they are perpendicular to the $\mathrm{FH}$ line as we have given before. In other words, the angles obtained on both sides are equal to one right angle, so that the $F B^{\prime} H C^{\prime}$ shape is also a rectangle. The area of a rectangle formed in this way is equal to the product of the $F B^{\prime}$ side by the $H F$ side, as we have seen in the previous lessons. Now we say that the area of the $F H C B$ parallelogram is equal to the area of the rectangle $F B^{\prime} C H^{\prime}$ we found. It is very easy to prove this. Yes, if you look at these two figures with attention, it will be seen that the $H C^{\prime} B F$ region is located in both the parallelogram and the rectangle. More than this parallelogram is the triangle $H C^{\prime} C$. Then more than that of the rectangle is the triangle FBB'. In this case, the fact that the area of the parallelogram is equal to the area of the rectangle requires these two triangles to be identical. Now, let's take out the triangle $C^{\prime} \mathrm{CH}$ with a pair of scissors and take a ruler and place its edge on the $B C^{\prime}$ side, and then slide the $C^{\prime} C$ edge of the $C C H$ triangle we have extracted forward against the ruler edge. When point $\mathrm{H}$ of the triangle comes to point $\mathrm{F}$, since the equality of $H C$ line to $F B^{\prime}$ line will not be distorted, point $C^{\prime}$ will also come to point $B^{\prime}$. In this case, since the $C^{\prime} H$ line will also be parallel to the $B^{\prime} F$ line, they will also overlap one another. Here, it can be concluded that these two triangles overlap each other, and therefore their areas are equal. In other words, the area of the rectangle is equal to the area of the parallelogram (Zeki, 1327/1909, pp. 63-64).

It is seen that the relationship established between rectangular and parallelogram shapes is also valid for area calculation. The method of making a hypothesis about the next information based on the previous information and proving this hypothesis is a product of the constructivism understanding. Following a similar hierarchy in the calculation of the area of a triangle, which is the next topic of Hendese-i Tecrubiyye, it is seen that the area of the triangle can be calculated through the area of the parallel side (Zeki, 1327/1909, p. 68-69).

\subsubsection{Are mathematical concepts included in the book in a way that they create mathematical meanings from students' concrete experiences and intuitions?}

In order for students to make sense of mathematics, especially at an early age, it is necessary to start from concrete experiences. In this section, it will be analyzed whether mathematical concepts are included in 6 textbooks of Salih Zeki in a way to form mathematical meanings based on concrete experiences and intuitions . 
Salih Zeki explains how to find the lengths of curved lines in his book Hendese-i Tecrubiyye as follows:

[...] Now let's draw a crooked line on the black board (Figure 12). We cannot measure the length

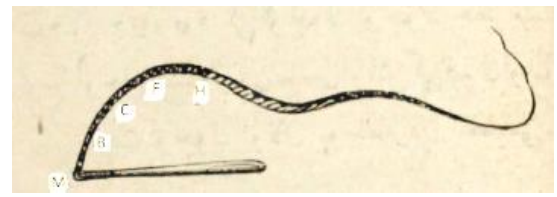

Figures 12

by putting the meter on this line. So what should we do? There is a very easy and accurate method to measure the length of such a curved line, which consists of taking a thin thread and tying one end to the end of the line $\mathrm{M}$ and then laying it on the curve until the other end. If the thread between the two ends of the curve is stretched, a line is formed, and the length of this line is equal to the length of the curve. However, it is not possible to use this method everywhere. For this reason, the curve is considered to be composed of end-to-end joints of small little lines such as $B M, B C, C F, F H$.

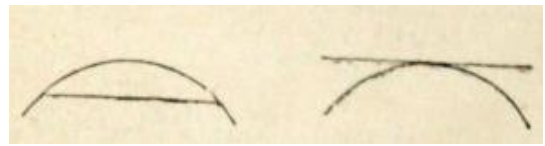

Şekil 13

Some touch only at one point. Such lines are also called "tangent" (Figure 13). After measuring the lengths of these small lines separately, if these lengths are added together, the total to be found is approximately equal to the length of the MH curve. Undoubtedly, the shorter and the smaller these lines, the closer their sum of lengths will be to the length of the curve (Zeki, 1327/1909, p. 89-90).

The sentence, "Undoubtedly, the shorter and the smaller these lines, the closer their sum of lengths will be to the length of the curve" contains the concept of infinitesimals. Salih Zeki has adopted a method advancing from concrete to abstract to measure the length of a curved line.

After defining an irregular curve and measuring its length, how to find the circumference of the circle, which is a smooth curve, is explained in the book of Hendese-i Tecrubiyye as follows:

... The curve we have previously drawn for you was a completely uneven curve. There are a number of smooth curves that are not necessary to be split into additional small lines or stretched over to find their length. In this way, smooth curves are calculated either with a measuring device or directly with the help of calculations. Here, the simplest of these curves is the curve called "circle". Let's take a piece of thread now. Let's connect the end of this thread to the M end of the blackboard with a nail or hold it with a finger. Let's put a chalk on the other end. In this case, let's draw a curve by keeping the chalk stretched and moving the chalk over the board. The curve we draw in this way is a circular curve in which the area of this curve in geometry is called "circle", the point $\mathrm{M}$ "center" and string itself "radius" and twice the length "diameter". Here we see that every point of this curve is always equal to the length of the string from the center M. In this case, the circle can be defined as consisting of a curved line equidistant from the center of the circle. If the radius of this circle is found, it is possible to find the length of the circle. Now, after drawing the circle, taking the thread ... (This sentence is incomplete in two different editions of the book). In this case, the circumference of a circle is equal to the number $\pi$ times the diameter, or twice the radius. In other words, if the radius is denoted by $\mathrm{r}$, circumference of a circle $=\pi \times 2 r$ (Zeki, 1327/1909, pp. 93-94).

Before the circumference calculation of the circle is explained, it is seen that the definition of the circle is made, the properties of its elements are specified, attention is drawn to the distinction between two different concepts of circle, and the circle is drawn concretely.

Salih Zeki's textbook Ilk Hendese Dersleri, Devre-i Âliye Ikinci Sene, subjects that are formed by rotating a surface area around any side and "moving objects" are analyzed in the book. The first of these is that "Cylinder, which is the object obtained by wrapping a rectangle around one of its sides". In the book, concrete examples that children of the period can easily come across in daily life are given, such as "minaret body, stovepipe, hair stove" so that students can visualize these shapes in their minds (Zeki \& Hâki, 1332/1914, p. 42). Therefore, mathematical concepts are associated with the daily life. 


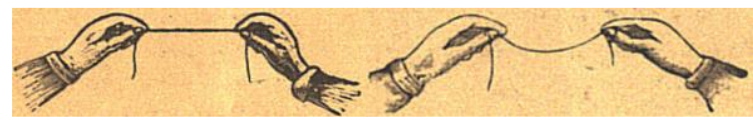

Figure 14

Salih Zeki 's textbook Illk Hendese Dersleri Birinci Sene attempts to tell the difference between the concepts of straight line (line) and curved line with the aid of a rope (Figure 14 ). It has been stated that the shape in which the rope is held taut at both ends shows the straight line, and the loose state shows the curved line. In addition, this situation associated with social life is supported with pictures. Along with the concept of line, the difference between curved surface and flat surface is also expressed. Therefore, concepts are explained in relation to each other and by giving concrete examples (Zeki, Ilk Hendese Dersleri (Birinci Sene), 1332 / 1914a, p. 5-8).

\subsubsection{Is there a problem solving method in the book?}

Problem solving method is a useful mathematics education approach that allows mathematics to be associated with social life. In this section, it will be examined whether or not problem solving method is included in 6 textbooks of Salih Zeki.

In his book named Hendese-i Tecrubiyye, Salih Zeki turns a daily life situation into a problem and deals with the issue of similarity:

When we go outside our school and walk a little bit, we see that there is a tree and a stream passes near it. How can we measure the shortest distance between the rod and the tree where we are, if we crossed the other side of the stream and planted a rod? (Zeki, 1327/1909, p. 17)

In the solution to this problem, the similarity issue in triangle has been used. Similarity is defined as follows:

[...] This small shape is a closed shape with three sides and three angles. The closed shape consisting of 3 sides and 3 angles is called "triangle" in geometry. Furthermore, since the small figure we draw on paper shows the triangle $M B G$ located between the tree $\mathrm{M}$ and the rod $\mathrm{B}$ on the ground $\mathrm{G}$, which makes it to be a small copy of triangle. A painting made like this is similar to the original. The pictures of houses, horses and cars we see in the books are examples of each made to resemble the real ones we see in cities. The horse picture we see in the sixth figure is a sample made similar to its original. The size of the real horse can be understood if all sides of this picture were measured carefully. For example, if the front leg is measured in the picture and it is twenty times smaller than the foot of the real horse, the other parts of the picture such as the head, tail and ear will be twenty times smaller than the other sides of the picture. A picture whose edge is reduced to a certain extent is called something picture-like. Here, the triangle $M^{\prime} B^{\prime} G^{\prime}$ we drew on paper is similar to the triangle $M B G$ we drew on the soil that actually exists. (Zeki, 1327/1909, p.23-24) .

The issue of similarity is kept hidden in the problem of a daily life situation, and the similarity issue has been tried to be perceived in accordance with the constructivist approach .

In Salih Zeki's book Hendese-i Tecrubiyye, a problem situation from daily life is chosen, in which the properties of an isosceles right triangle are described in a latent manner. The introduction to the subject in the book is as follows:

[...] In this lesson we will measure the height of a tree near us. Although this lesson may seem more difficult than the previous lessons, it is not so difficult. Measuring the height of such a tree is as if measuring the length of a line that can be reached at one end [but] not the other. In this, the end is the bottom of the tree that can be reached and the end that cannot be reached is the top of the tree (Zeki, 1327/1909, p. 20-21).

In the next topic of the book Hendese-i Tecrubiyye, the method used in the concept of similarity in the previous lesson was repeated for the right triangle and its properties. When creating an isosceles right triangle, a rectangular paper is first transformed into square paper, then a right triangle is obtained by cutting along the diagonal. The isosceles state of the right triangle is tested by folding the edges on each other and overlapping them.

\subsubsection{Are there any associations between mathematics subjects and real life?}

A mathematics lesson associated with daily life will be much more understandable, especially for younger students. In this section, it will be analyzed whether the association is made between mathematics subjects and real life in 6 textbooks of Salih Zeki.

Salih Zeki gave a general definition about the concept of area in his textbook Ilk Hendese Dersleri, Devre- $i$ Aliye İkinci Sene and related it to daily life as follows: 
To measure a surface means to search and find how many times another surface, which is accepted as a unit is present on this surface for comparison. The generally accepted unit surface for surfaces is the surface of a square, one meter in width and one meter in length, which is called square meter. [...] They say that how many of a surface can take out of a square meter is the square meter of that surface. E.g. If we say "the area of the classroom of this fifth grade classroom is 32 square meters", we can see that 32 square meters can be placed on the floor of this classroom, provided that the square meters are placed side by side and leave no gaps (Zeki \& Hâki, 1332/1914, p. 5).

This area definition will be used in calculating the area of all surfaces, which will be described later. Therefore, the relation among the definitions will be maintained until the end of the book. In this sense, it is possible to talk about a consistency in terms of content in the book. After the area definition is given, it is aimed to establish an association between mathematical knowledge and real life by giving examples from real life.

In Salih Zeki's book titled Ilk Hendese Dersleri, Devre-i Mutavassita Ikinci Kitap, the concept of volume is associated with daily life and defined as follows:

A volume is something that has a length, width and depth or height. The interior of a room, the space occupied by a brick on the wall, the cavity of a barrel are all volumes. A volume has both length, width, depth or height. To measure the volumes of objects, they accepted a known volume as 1 . The volume accepted as 1 is a "cube" in the form of a backgammon dice with a width, length and depth of one meter. The one whose length, width and height is 1 meter, are called "cubic meter". It is said that how many cubic meters a volume can contain, the volume of that object is the same cubic meter (Zeki, 1332 / 1914b, p.10).

The book explains what the concept of volume is, how the volume is measured and which measurement tools are used for this process. In addition, the concept of volume was associated with daily life to provide a quasi-real life experience for students. This concept of volume will be used in the volumes of all objects, which will be described later. For example, while introducing the prism shape for the volume calculations of prisms, visual elements such as stoves, which are frequently encountered by students in their daily lives, were used. With this method, which aims to establish a relationship between daily life and prism, it is aimed to construct the prism shape in the students' minds by infiltrating from the concrete entity to the abstract entity.

In Salih Zeki's textbook Ilk Hendese Dersleri Birinci Sene, the definition of parallel lines are explained as "lines that are on a plane and never intersect with each other, no matter how long they are extended". The concept of parallelism has been enriched with daily-life examples and pictures. For example, iron bars, lines on which musical notes are written, the feet of a stool are given as examples as seen in Figure 15 (Zeki, 1332 / 1914a, p. 10-11).

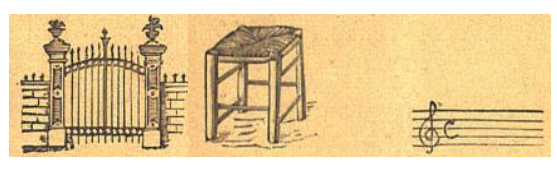

Figure 15

In the textbook titled Ilk Hendese Dersleri Birinci Sene, the concept of line is related to daily life as follows:

It is possible to see line in almost everything: For example, the edges of a cabinet made of household goods, the edges of the pages of a book cut around are all straight lines. Drawing the line: a tool called a ruler is used to draw a line. The ruler is a long board that has one edge cut straight, corresponding to a thin thread stretched at both ends. To draw a line with it, the ruler is laid on the paper and a pencil is taken and slid along its straight edge. In this case, the pen paints a line on paper (Zeki, 1332 / 1914a, p. 36-37).

After explaining in detail how to construct a line, how to draw the line between the two given points, how to extend a drawn line, and how to understand whether a ruler is working properly is shown in practice. In addition, the equipment that carpenters and gardeners obtain and use the straight line is explained. In this way, the concept of line has been traced in daily life and the concept has been enabled to flourish in students' minds. After making the necessary association, a given line segment was measured with a ruler (Zeki, 1332 / 1914a, p. 37-43). In this way, the students had the opportunity to learn by doing the relevant mathematical concepts. 
In the textbook titled Ilk Hendese Dersleri Birinci Sene, the acquisition of "constructing an angle equal to an angle" is associated with the carpentry profession. It is explained that the carpenters draw an angle with the same angle with the help of a tool they call a pliers and miter as follows:

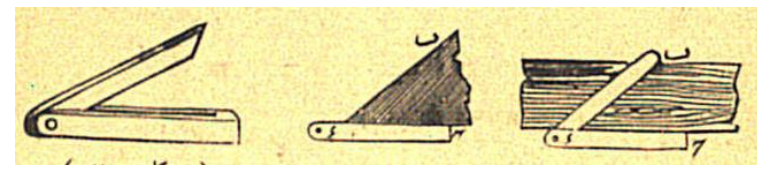

Figure 16

Carpenters use a kind of miter to paint an angle equal to one angle. This miter is almost like two rulers with two arms joined at each end(Figure 16). But around a nail at these converging ends, arms can open and close. With this $\widehat{B E C}$, the arms are opened to draw an angle equal to the angle (Figure 16) and the inner corner of the square is coincident to the $\mathrm{E}$ point and the inner edges $E C$ to the $E B$ lines. Then, without distorting the span of these arms, the tool is lifted and taken wherever it is necessary to draw this angle (for example a piece of wood) and a line is drawn each by the inner edges of the arms. The resulting angle $\widehat{B E C}$ will be the same as the previous angle (Zeki, 1332 / 1914a, p. 46-47).

As in this process, which carpenters frequently use in their work, Salih Zeki tried to make sense of mathematics by trying to associate almost every mathematical concept with daily life.

\subsubsection{Did the book provide the student with the necessary material and cognitive environment in constructing knowledge?}

The constructivist approach claims that knowledge can only be learned fully by reconstructing it in the mind. In this section, it will be examined whether Salih Zeki's 6 textbooks provide the necessary materials and cognitive environment in the construction of knowledge.

In Salih Zeki's textbook, all definitions are explained in accordance with the construction of knowledge. For example, the concept of field is expressed in the book Ilk Hendese Dersleri, Devre-i Mutavassita İkinci Kitap as follows:

In order to measure the area of a surface, the area of another surface is considered to be the unit to be compared. This unit is one square meter with a width and a length of one meter each. They call this "square meter". They say how many of these square meters a surface can take, the more square meters the area of that surface is. For example, when it is said that the floor of a room is 10 square meters, it should be understood as follows: The floor of this room has an area of 10 square meters (Zeki, 1332 / 1914b, p. 3-4).

This expression given for the area of any surface has provided students with a general view towards the concept of area in their minds. In this way, a relationship among mathematical concepts will be established. Following the general definition of the area, the areas of special geometric surfaces are explained in the book.

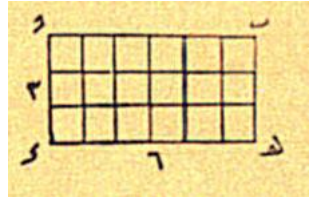

Figure 17

The area of a rectangle is equal to its base length times its height. For example, if there was a rectangle 6 meters wide and 3 meters tall, the product of these numbers would be $3 \times 6=18$, and the area of this rectangle would be 18 square meters (Figure 17). [This rule is explained as follows] If the length of the rectangle is divided into 6 meters and its height is 3 meters, and if the lines parallel to the sides of the rectangle are drawn from the separated point, 18 squares emerge, each of which is one square meter (Zeki, 1332 / 1914b, p. 4-5. ).

In Salih Zeki's books, after explaining the concept of area with a general definition, it is explained how to calculate the areas of geometric shapes in the light of the principles of this definition. In addition, Salih Zeki discussed the area of the parallelogram after constructing the area relation of rectangle and square in his 
textbooks. The area of the parallelogram is one of the last figures in classical textbooks. Salih Zeki deliberately handled the parallelogram after the rectangle and reached the concept of the area of the parallelogram from the concept of area of the rectangle. Later, it is seen that the area relation of the parallelogram reaches the area relation of the triangle, and the area relations of the polygons and the circle from the area relation of the triangle. The order in which Zeki deals with the area relations of these geometric shapes is suitable for the constructivist method.

In Salih Zeki's textbooks, pictures suitable for the social life of the period were included in relation to the subjects. In addition, geometric shapes are also properly depicted. This situation is an issue that supports the constructivist approach in the context of the student's concretization of the subject.

Problem situations derived from social life are one of the points that contribute positively to the construction of knowledge. Such problem situations are frequently encountered in the textbooks which have been analyzed. In addition, some of the questions given at the end of the sections and chapters are derived from daily life.

The involvement of the student in the process as part of the teaching activity is necessary for the construction of knowledge. In this context, drawing the geometric shapes in real dimensions explained theoretically in the textbooks will contribute to the absorption of the information. The second chapter of Salih Zeki's textbook titled Ilk Hendese Dersleri Birinci Sene is devoted to this subject (Zeki, 1332 / 1914a, p. 36-68). For example, the following exercises are made in the book: Drawing the line, drawing angles, drawing perpendiculars, drawing perpendicular with a square, dividing lines and angles into equal parts, drawing parallel, drawing tangents, drawing triangles, drawing quadrilaterals.

\subsubsection{Are there activities that will give students high-level thinking skills?}

In this section, it will be examined whether Salih Zeki's 6 textbooks include activities that will provide students with high-level skills.

Salih Zeki included activities in some of his textbooks that give students high-level thinking skills. For example, in the third chapter of the book named Illk Hendese Dersleri, Devre-i Mutavassita Ikinci Kitap, some exercises of the previously-learned subjects are included:

Tile floors with stones: drawing a shape that matches a shape, drawing another shape that matches the area of a shape, measuring the distance between two points that cannot be reached directly from one place to another, measuring the length of a line that cannot be reached at one end, measuring the height of a tree (Zeki, 1332. / 1914b, pp. 36-52).

These activities will improve students' skills to transfer mathematical knowledge to daily life.

After discussing the volume of regular geometric objects in the third and fourth chapters of Salih Zeki's Illk Hendese Dersleri, Devre-i Aliye İkinci Sene, in the fifth chapter, the exercise of "the volume of an irregular object" is made. Students are expected to make a high-level application of the volume concept they have learned through this exercise. For example, how to calculate the volume of a pear is expressed with the following activity:

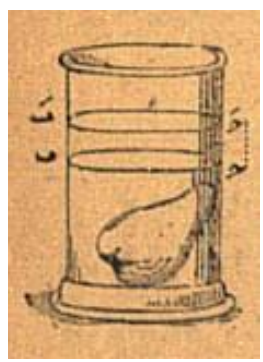

Figure 18

First of all, to find the volume of a pear shown in Figure 18, we take a cylindrical hollow glass container and fill some water into it and mark the $C B$ level of this water. Next, we put the pear in it. In this case, after the water level rises, we mark the $C^{\prime} B^{\prime}$ level of the water. In this case, we understand that the volume of the pear thrown into the water is equal to the volume of the $B C C^{\prime} B^{\prime}$ cylinder.

Here is the height of $B C C^{\prime} B^{\prime}$ cylinder $\left|B B^{\prime}\right|=0,4$ meters, if the width (diameter) of the cylinder is 0,68 meters from the inside of the mouth:

Volume of $B C C^{\prime} B^{\prime}$ cylinder $=0,34 \times 0,34 \times 3,1416 \times 0,4=0,145267$ cubic meters.

The volume of the pear would be 0,145267 cubic meters. 
In the third chapter of the book named Ilk Hendese Dersleri, Devre-i Mutavassita Ikinci Kitap, some exercises of the previously-learned subjects are included:

Tile floors with stones: drawing a shape identical to a shape, drawing another shape equivalent to the area of a shape, measuring the distance between two points that cannot be reached directly from one place to another, measuring the length of a line that cannot be reached at one end, measuring the height of a tree (Zeki, 1332 / 1914b, pp. 36-52).

\subsubsection{Has a relationship been established with other disciplines?}

In this section, it will be identified whether any relationship has been established with other disciplines in 6 textbooks of Salih Zeki.

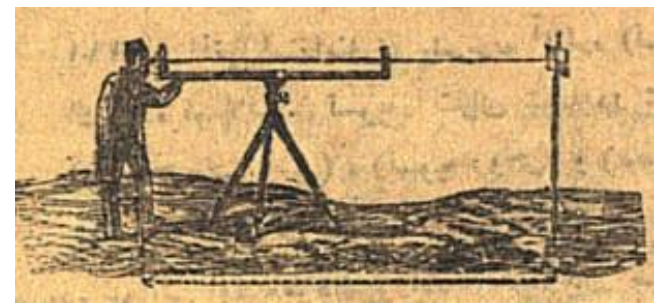

Figure 19

In the sixth chapter of Salih Zeki's textbook Ilk Hendese Dersleri, Devre-i Aliye İkinci Sene, there are perimeter and area formulas for land and calculation of the land limits, and the calculation of the boundaries of the lands are discussed in the seventh chapter (Zeki \& Hâki, 1332/1914, p. 57-72). After introducing the field measurement tools, it is described how the calculations will be made with a content enriched with pictures. In this context, a relationship has been established between the geometry knowledge learned in the book and cartography. There are examples of land measurements in other textbooks.

By establishing a direct relationship between field measurements and cartography discipline and mathematics, it was included in the textbooks. On the other hand, no direct relationship has been established between geometry and other disciplines in the textbooks.

\subsubsection{Are multiple display tools such as graphics, pictures, figures included in the content?}

In this section, it will be examined whether Salih Zeki's 6 textbooks include sufficient number of multiple display tools such as graphics, pictures and figures.

Pictures and figures have a large place in all textbooks of Salih Zeki. Pictures consist of photographs taken from social life. This situation made it possible to establish a association between daily life and mathematics. For example, the picture used to exemplify sphere is as follows: (Zeki ve Hâkî, 1334/1915, p.11)

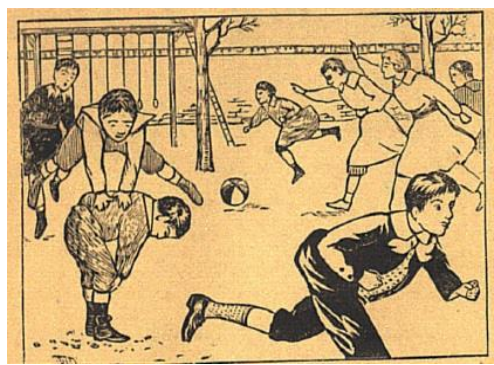

Figure 20

The geometric shapes used are also prepared in a way that allows the subject to be understood. For example, in the book Ilk Hendese Dersleri, Devre-i Âliye İkinci Sene, the following figure is used when talking about the area calculation of the rectangle: (Zeki \& Hâki, 1332/1914, p.6) 


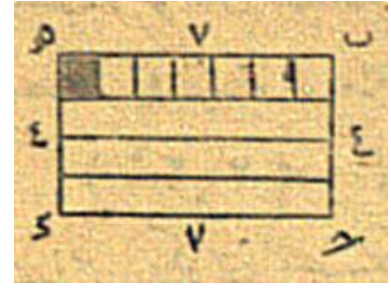

Figure 21

In his book Nazarî and 'Amelî Mücmel Hendese, Salih Zeki enriched the subject by relating the volume of sphere to the volume of the cone with the following figure with the aid of the following figure: (Zeki, $1322 / 1904$, p.215)

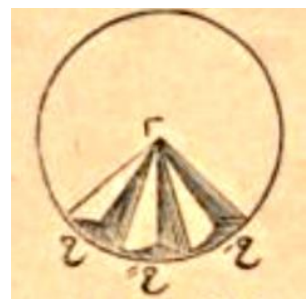

Figure 22

Salih Zeki used many pictures and figures in his textbooks, as in the two abovementioned examples in this chapter.

3.1.11. Are the practice problems of questions on the subject organized in a way that improves the student's reasoning skills?

In this section, it will be determined whether the practice problems included in 6 textbooks of Salih Zeki are organized in a way that will improve the reasoning skill of the student.

There are two kinds of practice problems in Salih Zeki's textbooks. The first is "What is Geometry? Give examples (Zeki \& Hâkî, 1334/1915, p. 11). These are exercise questions that measure knowledge directly. There are exercises of this type at the end of each chapter. The second is, "What would be the height of a square perpendicular prism whose height is equal to one side of its base if its surface area is 165.68 square meters (Zeki \& Hâkî, 1334/1915, p. 83)?” There are also problems that will develop the student's reasoning skills.

Salih Zeki also included reasoning questions associated with daily life in his practice problems:

What is the height of the minaret in a place where the shadow of a minaret is 10 meters 25 centimeters and the shadow of a tree perpendicular to the ground with a height of 1 meter 10 centimeters is 35 centimeters (Zeki, 1327/1909, p. 42)?

\subsection{Examples with Behavioural Character in Textbooks}

In this section, examples that do not comply with the constructivist character in Salih Zeki's textbooks will be included. In the first Hendese Lessons book, how to calculate the circumference of a circle is explained as follows:

Whether a circle is large or small depends on its diameter. That is, the more times a circle gets bigger or smaller in diameter, the more times its circumference gets larger or smaller. As a result of some calculations and many exercises, it has been found that the circumference of each circle is 3,1416 times larger than its diameter. In other words, in order to calculate how long a circle circumference is, the diameter of that circle must first be measured, then the number must be multiplied by the number 3,1416 . This number is fixed and denoted by the Greek letter " $\pi$ " and pronounced as "pi".

\section{[...] So the circumference of the circle $=$ diameter $x \pi$ (Zeki \& Hâkî, 1334/1915, p. 24).}

The remarkable point in the paragraph above is that the circumference of the circle is stated as "As a result of some calculations and many exercises, the circumference of each circle has been found to be 3,1416 times larger than its diameter. "In this approach, it is seen that the circumference of the circle is given to the student as a rule. Since the meaning of the number is not explained, the relationship between the number $\pi$ and the circumference of the circle is not explained clearly. Nevertheless, a student who responded to the above explanation said "What 
is the circumference of a circle with a radius of 4 meters?" will be able to answer the question correctly. But meaningful learning will not occur.

In the first part of his textbook Illk Hendese Dersleri Birinci Sene, Zeki introduced geometric shapes such as line, circle, parallelism, angle, polygon, triangle and the basic elements of these shapes. After explaining the concepts of triangle such as side, corner and height, he dealt with angle in triangle. He reported that the sum of the interior angles of the triangle is equal to two right angles, but he did not question why this was the case (Zeki, 1332 / 1914a, p. 27-28).

Since the aforementioned textbooks are planned to be a continuation of each other, some topics built with a constructivist approach are expressed in a completely abstract approach in the next textbook. For example, in the introduction of Salih Zeki's textbook Illk Hendese Dersleri, Devre-i Âliye, İkinci Sene, it was emphasized that this book is a continuation of the books named Hendese-i Tecrubiye and Ilk Hendese Dersleri, Devre-i Âliye, Birinci Sene (Zeki \& Hâki, 1332/1914, p.2). In this book, Salih Zeki describes the area of the parallelogram using the area of the rectangle as follows:

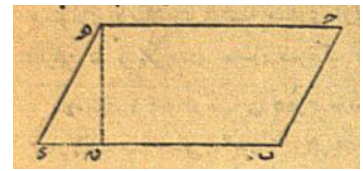

Figure 23

The area of the parallelogram is equal to the product of its base and the height of the base. [This rule can be proved as follows] The parallelogram in Figure 23 is equal to the [area] rectangle to be drawn on the BE side at HG height (Zeki \& Hâki, 1332/1914, p. 7).

Although the area of the parallelogram is described in relation to the area of the rectangle, it is not clearly explained in this book how the area of the parallelogram equals the area of the rectangle.

\section{Discussion and Conclusion}

Mathematics, which is the basis for obtaining and developing scientific knowledge, is at the top of the educational goals of all societies. On the other hand, the number of people who can perceive and learn mathematics has always been in the minority in societies that have emerged throughout human history. Learning and teaching mathematics is considered a privilege. The fact that today's developed states are more advanced than other societies in fundamental sciences can be given an example for this situation. States that are aware of the importance of mathematics are in an effort to teach their young individuals mathematics in the best way. Therefore, mathematics education is a constantly changing and developing discipline. There are different strategies that math educators work on. One of the accepted mathematics education strategies is the constructivist education approach. It has been found out that Salih Zeki prepared geometry textbooks that contain the basic criteria of constructivist education approach. Among the books examined, a letter was written as a guide for the mathematics teachers who will read the textbook in the preface of the textbook titled $\dot{I} l k$ Hendese Dersleri Birinci Sene. In this letter, Salih Zeki stated that he is against memorizing with the sentence "... the subjects in the book will be told to children without being memorized" and that the students actively participate in the lesson instead of being passive learners. To search for the traces of geometry subjects in nature and associate mathematical concepts with daily life with the sentence " $\ldots$ the subjects of the first chapter will be shown to children gradually in the classroom, in the garden, briefly everywhere, and the related exercises of the second chapter will also be done together" "... Children should never be made to memorize any definitions, explanations, and so on." On the contrary, he wanted the students to reconstruct the definitions in the mind of the student and to enable students to discover the mathematical relations, instead of memorizing the definitions with the sentence "These descriptions should be made for them by making shapes." The general framework expressed by Salih Zeki in this preface contains the basic criteria of the constructivist education approach. It has also been found out that Salih Zeki adhered to these criteria in all six textbooks.

In his book, Salih Zeki Hendese-i Tecrubiyye adopted a method that proceeds from concrete to abstract to measure the length of a curved line. In the constructivist education approach, subjects are given in relation to each other. Therefore, if any topic is related to the next topic, the student is prepared for that topic. The sentence "Undoubtedly, the shorter and the smaller these lines, the closer their length will be to the length of the curve" (Zeki, 1327/1909, p. 89-90) contains the concept of infinitesimals. The integral issue is not something that students of this age group can learn. However, considering that the Hendese-i Tecrubiyye textbook was prepared for middle school 3rd grade students (in today's sense), it can be thought that the students' mathematical perceptions were prepared for the next educational institution, the high school, by introducing the infinitesimals logic to the student.

In Hendese-i Tecrubiyye, the issue of similarity is hidden in the problem situation of daily life, and the issue of similarity is tried to be perceived. A course organized with a behavioral approach, which we can consider as 
the opposite of the constructivist approach, could be as follows: "In order for a triangle ABC and DEF to be similar, there must be a constant ratio between the AB and DE side, AC and DF, BC and EF sides." Transfer of knowledge to the student with such an approach will be an indication that the concept of similarity is considered as an absolute mathematical truth and must be memorized. This mathematical knowledge can only be memorized and not grasped.

In the book named Ilk Hendese Dersleri (Birinci Sene), a number of things that carpenters frequently use in their work are included in the learning environment. This will contribute to the student's process of constructing the angle concept. The fact that the age group that the book addresses is students of the age group 10-12 makes it compulsory to give these concepts to the students in a concrete way. Salih Zeki tried to make sense of mathematics by trying to associate almost every mathematical concept with daily life.

Interdisciplinary communication has an important place in a mathematics education organized with a constructivist approach. By establishing a direct relationship between field measurements and cartography discipline and mathematics, this was included in the textbooks. In that period, schools providing education at secondary school level met the Ottoman civil servant needs. Therefore, the Ottoman Empire, an agricultural state, needed government officials to measure the land. In this context, it is possible that the subject of cartography are included in the geometry textbooks. On the other hand, no direct relationship is established between geometry and other disciplines in the textbooks.

One of the most important materials that contribute to the shaping of mathematics in young age group students in the world of thought is the enrichment of the learning environment with visual elements. In this context, there are many pictures and figures in Salih Zeki's textbooks.

Salih Zeki has included many practice problems in all textbooks. While some of these are at the knowledge level, some of them consist of questions that improve students' reasoning skills.

Behavioral approach, which is one of the learning theories, explains learning with the observable effects of the environment on behavior instead of cognitive processes. This approach is based on the assumption that learning products are observable behaviors and these behaviors can be changed. Behaviorists do not work on how a person learns, but on what stimuli the brain responds to. According to this approach, the subject to be taught is divided into small behaviors and these behaviors are given to the student in turn. Behaviorists argue that permanence in learning will be achieved with plenty of repetitions and exercises (Olkun \& Toluk, 2007). According to this approach, topics are given in sub-headings. The student is expected to use the rules and formulas related to the subject effectively. In the behavioral approach, a definition is given about the subject, then a sample solution is made, and then the next topic is started to tackle upon. Definitions need not be correlated. The student learns more methods. From this perspective, in the book Ilk Hendese Dersleri (Birinci Sene), the circumference of the circle "As a result of some calculations and many exercises, it has been found that the circumference of each circle is 3,1416 times larger than its diameter" (Zeki \& Hâkî, 1334/1915, p.24.) is remarkable. In this approach, it is seen that the circumference of the circle is given to the student as a rule. Since the meaning of the number is not explained, the relationship between the number $\pi$ and the circumference of the circle is not clearly explained and later grasped by students. Nevertheless, a student who responded to the above explanation said "What is the circumference of a circle with a radius of 4 meters?" will be able to answer the question correctly. But meaningful learning will not occur. Instead, as stated in the book Hendese- $i$ Tecrubiyye, if it is explained that the ratio of the circumference of any circle to its diameter corresponds to the number, so the product of the diameter by the number will also give the circumference of the circle, and the concept of the circumference of the circle will be constructed in the individual's mind. Therefore, this section of the book is suitable for the behaviorist approach. Salih Zeki adopted a behavioral approach by giving only formulas and correlations in a low number in textbooks.

It has been revealed in the Henry Poincaré translations and the article "Nâmütenâhî" that Salih Zeki is close to the school of intuitionism, which is one of the approaches of mathematical philosophy (For detail information, please see Takıcak, 2016). He applied the propositions of this school, which he chose to base mathematics, in mathematics education. The constructivist understanding of education is a mathematics education strategy derived from Intuitionism, one of the 20th century mathematical philosophy movements. Therefore, it is seen that Salih Zeki consciously follows a target-oriented way both in explaining mathematics and in mathematics education. In this case, it can be said that Salih Zeki foresees a mathematics education of philosophical basis in a planned and programmed manner and want to give direction to Turkey's math education with this prediction.

It is noteworthy that the constructivist approach, which is thought by mathematics educators to be one of the most effective methods for mathematics education today, was used by Salih Zeki in textbooks at the beginning of the 20th century. Since the beginning of the 19th century, continuous reforms were made in education, especially in mathematics education. The reforms in mathematics education were mostly in the form of reorganization of teaching programs and textbooks. It is seen that the geometry textbooks written by Salih Zeki and the textbooks used in mathematics education today have a constructivist character. Therefore, it has been determined in this study that the project of equipping the textbooks with a constructivist character, which is far from memorization, in order to increase the quality of mathematics education today, was also applied in the first years of the Republic by Salih Zeki. In this case, it can be seen that developing textbooks and curriculums alone 
is not sufficient to improve mathematics education. The causes of Turkey's lagging behind in mathematics education and mathematical production makes necessary for a more in-depth research.

\section{Recommendations}

In addition to this study on the textbooks of Salih Zeki, the textbooks written by other mathematicians of the period can be analyzed in a similar way. In this way, the state of mathematics education in the last period of the Ottoman Empire and the first years of the Republic will be analyzed in detail.

In the analysis of the problems experienced in Turkey's mathematics education, apart from the curriculum which is regarded as the only one variable, it should be focused on potential variables such as student-teacher and environmental conditions. 


\section{Osmanlı Matematik Eğitiminde Yapılandırmacı Yaklaşım: Salih Zeki}

\section{Giris}

Matematik eğitiminde, matematik felsefesi sınıf ve okul ortamında matematiği nasıl öğrendiğgimizi ve öğrettiğimizi belirlemektedir. Eğer matematik, Platonist geleneğin savunduğu gibi keşfedilmeyi bekleyen ideal bir varlık olarak bulunuyorsa, o zaman okulların, matematiği doğrular, tanımlar ve algoritmaların sıradan bir bütünü olarak sunmaları yeterli olacaktır. Bu açıdan bakıldığında matematik, öğrencilerin hiçbir muhakeme yapmadan doğru olarak kabul etmek zorunda olduğu, değişmez bir bilgi birikimini aktarmaya benzer. Ancak, eğer matematik kültürel, yaratıcı ve deneysel bir aktivite ise, o zaman öğrencilerin benimsedikleri metodoloji, klasik matematikten ne kadar farklı olursa olsun kendi matematiksel bilgilerini yapılandırma konumunda olacaktır (Handal, 2009). Bu metodolojiye uygun yaklaşım yapılandırmacılıktır.

Yapılandırmacıılık yaklaşımı bilgi, bilginin doğası, nasıl bildiğimiz, bilginin yaygınlaştııılması sürecinin nasıl bir süreç olduğu ve bu sürecin nelerden etkilendiği gibi konularla ilgilenmekte ve düşünceleri eğitimsel uygulamalara temel oluşturmaktadır (Demir ve Şahin, 2009). Bu yaklaşıma göre öğrenme, bilginin pasif bir biçimde ele alımı değil, kavramların yapılandırılmasının aktif olarak devam ettiği bir süreçtir, bu süreçte ezberleme değil anlama vurgulanır (Gömleksiz ve Kan, 2007). Yapılandırmacılar, bilginin kendi yaşantısını anlamlı kılmaya çalışan birey tarafından yapılandırıldığını ve çevreden pasif bir biçimde alınmadığını savunmaktadır. Bireyler doldurulmayı bekleyen boş variller değillerdir (Koç ve Demirel, 2004). Dolayısıyla yapılandırmacılık bireyin zihinsel inşa süreci ile öğrenenin dünyasında gerçekleşen biliş temelli bir yaklaşımdır ve bilginin inşasında öğrenen, öğrenme sürecinin merkezindedir (Brooks \& Brooks, 1999). Bir başka açıdan bakıldığında yapılandırmacılık, yeni karşılaşılan bilgileri önceki bilgilerle ilişkilendirerek öğrenmek, böylece daha önceden bilinen konulara bağlı olarak yeni öğrenmeler oluşturmaktır (Arslan, 2007). Yapılandırmacı öğrenme programında öğrenme içeriği öğrencilerin ilgileri ve gereksinimlerine yanıt vermenin yanında, gerçek yaşamla bağlantılı ve özgün olmalıdır. Başka bir deyişle konu merkezli tasarım yerine öğrenen merkezli tasarım uygulanmalıdır. Öğrenenin öğrendiğini yapılandırması ön plandadır (Koç ve Demirel, 2004).

Yapılandırmacı yaklaşımda bilginin nasıl oluşturulduğu konusunda üç temel görüş vardır:

1. Bilişsel Yapılandırmacılık (Cognative Constructivism)

2. Sosyal Yapılandırmacilık (Social Constructivism)

3. Radikal Yapılandırmacılık (Radical Constructivism)

Söz konusu yaklaşımların üçünde de bilgi pasif olarak dışarıdan alınmaz. Bu yaklaşımlarda ortak nokta, bilginin zihinde yapılandırılması ve bireyin bilgiyi kendisinin oluşturmasıdır. Öğrenme için uygun ortamların hazırlanması da bireyin bilgisini kendisinin oluşturması için etkili olan etmenlerden biridir. Öyle anlaşıllyor ki, ne öğrenmişsek, ne öğreniyorsak ve ne öğreneceksek zihnimizde yapılandırarak öğreniriz. Yani, deneyimlerimiz aracılığıyla yanılarak, tartışarak, düşündüğümüzü ve yaptığımızı sahiplenerek, analiz ederek, yapıp yaşayarak öğreniriz (Delil ve Güleş, 2007).

Yapılandırmacılık ilk ortaya çıktığı dönemde öğrencilerin bilgiyi nasıl öğrendiklerine odaklanmıştır. Zamanla gelişimini sürdüren yapılandırmacı anlayış, öğrencilerin bilgiyi nasıl inşa ettiklerini sorgulamaya başlamıştır (Erdem ve Demirel, 2002).

Yapılandırmacılığın genel karakterine uygun bir matematik eğitimi nasıl verilebilir? Paul Ernest’a göre yapılandırmacı matematikçiler şu görüşe sahiptirler: Klasik matematik güvenli olmayabilir ve matematiğgin "yapılandırmacı" metotlarla yeniden inşa edilmeye ihtiyacı vardır. Ayrıca yapılandırmacılar, hem matematiksel doğruların, hem de matematiksel nesnelerin varlıklarının yapılandırmacı yöntemlerle inşa edilmesinin gerekli olduğunu iddia etmektedirler. Bu, doğruyu veya varlığ inşa etmek için çelişki ile ispata dayanan yöntemlere karşı, matematiksel inşaların gerekli oldukları anlamına gelmektedir (Ernest, 2004). Yapılandırmacıların bu son iddiası, matematik felsefesinin 19. yüzyılda matematiği yeniden temellendirme çabasının bir ürünü olarak Brouwer'in öncülüğünde ortaya çıkan Sezgicilik akımının, matematiksel ispat yöntemlerinden "olmayana ergi" yöntemini reddetmesi ile paralellik göstermektedir.

Bazı yapılandırmacılar, matematiğin kâğıt ve kalem ile ortaya konan inşacı yöntemlerin çalışmasıı olduğu düşüncesini muhafaza etmelerine rağmen, Brouwer önderliğindeki daha sert sezgici görüş, matematiğin öncelikle zihinde yer aldığını, hâlihazırda birikmiş olan matematiğin ikinci sırada geldiğini iddia etmektedir. Bir sonucun hem klasik hem de yapılandırmacı ispatlarının olduğu sınırlı alanlarda, yapılandırmacı olan ispatlar daha bilgilendirici olmaları nedeniyle tercih edilir. Klasik bir varlık ispatı ise sadece varoluşun mantıksal zorunluluğunu gösterebilirken, yapılandırmacı bir varlık ispatı, var olduğu iddia edilebilen matematiksel bir nesnenin nasıl inşa edilebildiğini göstermektedir (Ernest, 2004).

19. yüzyılın başlarında matematiğin temellerinde yaşanan bunalım neticesinde, matematiği tekrar sağlam temellere oturtmak düşüncesi 3 paradigmanın doğmasına sebep olmuştur: Mantıkçılık (Logicism), Formalizm 
(Formalism), Sezgicilik (İntuitionism) (Handal, 2009). Ernest ise The philosophy of Mathematics Education kitabında bu 3 paradigmayı tanıtırken mantıkçılığın ve formalizmin yanında üçüncü paradigma olarak yapılandırmacılığ belirtmek için de Constructivism (Intuitionism) biçiminde bir kullanıma yer vermiştir (Ernest, 2004). Ernest gibi bazı felsefeciler sezgiciliği ve yapılandırmacılığı birbirinin yerine kullanabilmektedirler.

Matematik eğitimi genel anlamda 2 temel strateji üzerine oturtulmaktadır. Bunlardan birincisi; matematiksel bağıntıların, formüllerin, ilişkilerin bir bütün olarak, eğitim verilecek olan birey ya da bireylerin kişisel özellikleri dikkate alınmaksızın sürecin dışında tutularak sunulması biçiminde ortaya çıkan stratejidir. $\mathrm{Bu}$ stratejide öğrenci eğitim öğretim faaliyetlerinde pasif alıcı konumundadırlar. İkincisi ise; matematiğin bir bütün olarak algılandığı, matematiksel kavramların birbirleri ile ilişkilendirildiği, formül, bağıntı ve teoremlerin neden sonuç ilişkisine bağlı kalınarak açıklığa kavuşturulduğu, matematiksel bilginin gelişim sürecinden öğrencinin haberdar edildiği, bireylerin eğitim öğretim sürecinde aktif olarak konumlandığı, matematiksel bilginin anlamlandırıldığı, matematiğin öğrenci zihninde yeniden inşa edildiği stratejidir. Yapılandırmacı eğitim anlayışı olarak isimlendirilen ikinci yaklaşımın temel özellikleri şu şekilde ifade edilebilir:

- Yapılandırmacı yaklaşımda, anlama, problem çözme, bilgiyi yeni durumlara uyarlama yeteneğini geliştirme hedeflenmektedir. Bu yaklaşım eğitimde baskın konumda bulunan gelenekselci ve nesnelci paradigmaya karşıdır. Yapılandırmacılara göre bilgi, duyu organları ile çevreden pasif bir biçimde alınamaz, öğrenen tarafından etkin bir biçimde yapılandırılır. Yapılandırmacı öğrenmede amaç, öğrenenlerin önceden belli bir hiyerarşiye göre belirlenmiş hedeflere ulaşmalarına yardımcı olmak değil; öğrenenlere bilgiyi zihinsel olarak anlamlandırmaları için öğrenme firsatları sağlamaktır. Piaget ve Vygotsky yapılandırmacılığı en çok etkileyen bilim adamlarıdır. Yapılandırmacı eğitim programında tümdengelim ve tümevarım yaklaşımları kullanılmaktadır. İçerik temel kavram ve ilkeler etrafinda yapılandırılmaktadır (Çelik, 2006).

- Yapılandırmacı öğrenme, Piaget (1896 - 1980) ile özdeş görünmesine rağmen kökleri yaklaşık 100 yı1 geriye giden bir kuramdır (Altun, 2004).

- Öğretme değil, bir öğrenme teorisi olan yapılandırmacılık şu üç varsayıma dayanır (Delil ve Güleş, 2007):

- Bilgi kişisel bir katkıda bulunulmadan inşa edilemez.

- Anlama, adaptasyon sonucu ortaya çıkar. Kişi kendi deneyimleri, bilgi ve birikimleriyle tartışılan konu arasında uyumlandırma sağlayarak konuyu anlar.

- Bilgi, etkileşim sonucu oluşturulur. Kullanılan dil ve içinde bulunulan sosyal çevre bu etkileşimde önemli rol oynar.

Yapılandırmacı yaklaşım kabaca 20.yüzyılın ortalarından itibaren matematik eğitiminde sıklıkla kullanılmaya başlanmıştır. Fakat çok daha önce yapılandırmacı yaklaşıma örnek olabilecek münferit örnekler bulmak mümkündür. Bu makalede de son dönem Osmanlı matematikçilerinden Salih Zeki'nin, matematik eğitimine yaklaşımının yapılandırmacı bir karakter taşıyıp taşımadığı yazdığı ders kitapları aracılığıyla tespit edilmiştir.

\subsection{Salih Zeki}

Osmanlı Devleti'nin son döneminde yaşamış önemli bilim adamlarından biri olan Salih Zeki, 1864 yılında İstanbul'da doğdu. Darüşşafaka'nın ilk mezunlarından olan Salih Zeki Telgraf Nezareti Fen Kalemi'nde göreve başladı. Kısa süre içinde çalıştığ 1 kurum tarafından Paris’e telgraf mühendisliği eğitimi alması için gönderildi. Burada kaldığı iki yıl sürecinde mühendislik eğitiminin yanı sıra matematik ile de ilgilendi. Matematik tarihinin önemli simalarından Henri Poincaré'den dersler aldı ve onun bilim ve felsefeye dair görüşlerini benimsedi. Eğitimini tamamladıktan sonra devletin çeşitli kademelerinde üst düzey görevler aldı. Bunlardan biri olan Rasathane-i Âmire müdürlüğü esnasında astronomik gözlemlere bizzat iştirak etti. 1900 yılından itibaren Dârü'lFünûn'un Riyaziye şubesinde dersler vermeye başladı. 1913-1917 yılları arasında Dârü'l-Fünûn Umum-i Müdürlüğü (Rektörlük) görevini yürüttü. 1921 yılında vefat edinceye kadar matematik bölümünde ders vermeye devam etti.

Osmanlı'nın son döneminde çok önemli görevleri üstlenen Salih Zeki üzerine bugüne kadar çok sayıda biyografi çalışması yapılmıştır. Ayrıca Salih Zeki'nin kitapları ve makaleleri üzerine çeşitli yazarlar tarafından değerlendirme yazıları kaleme alınmıştır. Diğerlerinden farklı olarak eldeki bu makalede ise Salih Zeki'nin matematik eğitimcisi kimliği ön plana çıkarılmıştır. Bu çalışmada Salih Zeki’nin 1907-1915 tarihleri arasında yazmış olduğu altı adet geometri ders kitabı, günümüzde matematik eğitimcileri tarafından 20. ve 21. yüzyıllarda etkili öğretim stratejilerinden biri olarak kabul edilen Yapılandırmacılık (Constructivism) yaklaşımı açısından değerlendirilmiştir. Salih Zeki'nin pür matematikçi ve matematik felsefecisi kimliklerinin yanı sıra matematik eğitimcisi kimliğinin, söz konusu ders kitaplarında izi sürülmüştür. Dolayısıyla ne öğrettiğinden çok, nasıl öğrettiğinin üzerinde durulmuştur. 
Söz konusu ders kitapları bugünkü ortaokul seviyesinde olup, birbirlerini tamamlayacak şekilde planlanmıştır. Bu kitapların isimleri ve okutulduğu yerler şu şekildedir:

1. Hendese-i Tecrubiyye: Salih Zeki tarafından 1909 yılında (İlk baskısı 1892 yılında yapılan bu kitabın birden fazla baskısı yapılmıştır. Makalede 1909 tarihli baskısı kullanılmıştır) bütün rüştiyelerin (ortaokul) 3.sınıflarında okutulmak üzere Maarif Nezareti'nin talebiyle yazılmıştır. Kitap, nokta, doğru, düzlem, uzunluk, alan ve hacim konularını içermektedir.

2. İlk Hendese Dersleri, Devre-i Âliye Birinci Sene, Üçüncü Kitap: Salih Zeki ve Hamazasb Hâki tarafından 1915 yılında, Mekteb-i İbtidâiye'nin Devre-i Âliye birinci sınıflarında (ortaokul 1) okutulmak üzere Maarif Nezareti'nin talebiyle yazılmıştır. Kitap, açı, açının özellikleri, açıların inşa edilmesi, geometrik aletler, doğruların birbirlerine göre konumları ve inşası, temel geometrik şekiller ve özellikleri gibi konuları ihtiva etmektedir.

3. İlk Hendese Dersleri, Devre-i Âliye İkinci Sene, Dördüncü Kitap: Salih Zeki ve Hamazasb Hâki tarafından 1915 yılında, Mekteb-i İbtidâiye'nin Devre-i Âliye ikinci sınıflarında (ortaokul 2) okutulmak üzere Maarif Nezareti'nin talebiyle yazılmıştır. Kitapta dairenin özellikleri, düz ve eğri çizgi, düz ve eğri yüzey, silindir, koni gibi konular yer almaktadır. Ayrıca arazi ölçümünde kullanılacak aletlerin geometrik alt yapıları ve kullanım talimatları da kitapta anlatılmaktadır.

4. İlk Hendese Dersleri, Birinci Sene: Salih Zeki tarafından 1914 yılında, Mekteb-i İbtidâiye'nin üçüncü sınıflarında (ortaokul 3) okutulmak üzere Maarif Nezareti'nin talebiyle yazılmıştır. Üç bölümden oluşan kitabın birinci bölümünde tanımlar, ikinci bölümünde düzlemsel şekiller ve özellikleri, üçüncü bölümde söz konusu geometrik şekillerin çizimleri ve inşası yer almaktadır.

5. İlk Hendese Dersleri, İkinci Sene, Devre-i Mutavassıta, İkinci Kitap: Salih Zeki tarafindan 1914 yılında, Mekteb-i İbtidâiye'nin dördüncü sınıflarında (ortaokul 4) okutulmak üzere Maarif Nezareti'nin talebiyle yazılmıştır. Üç bölümden oluşan kitabın birinci bölümünde alan hesabı, ikinci bölümünde hacim hesabı, üçüncü bölümünde ise günlük hayatta karşılaşılan problemlere yönelik geometrik çözümler yer almaktadır.

6. Nazarî ve 'Amelî Mücmel Hendese: Salih Zeki tarafindan 1911 yılında, sadece 'amelî hendese okutulan rüştiye öğrencilerinin nazarî hendese tahsillerini kolaylaştırmak amacıyla yazılmıştır. Kitapta, çizgiler, açılar, düzlemsel şekiller, alan hacim hesabı, uygulamalar yer almaktadır.

Yaklaşık 100-150 yıldır öğrencilere matematiğin daha iyi öğretilebilmesi amacıyla matematik eğitimine yönelik değişiklikler yapılmıştır. Bu değişikliklerin büyük bir kısmı da müfredat özelinde gerçekleşmiştir. Fakat istenen seviyede gelişim kaydedilemediği aşikârdır. Problemin kaynağının tespiti için sadece bugün yapılanlara ya da yapılmayanlara odaklanmak yerine Osmanlı'nın son dönemleri ile Cumhuriyet'in ilk yıllarında gerçekleştirilen matematik eğitimini analiz etmek faydalı olacaktır. Ülkemizde bu konuda yapılmış çok fazla araştırma yoktur. Eldeki bu çalışmanın amacı son dönem Osmanlı matematikçilerinden Salih Zeki'nin yazmış olduğu ders kitaplarının yapılandırmacı karakter taşıyıp taşımadığının belirlenmesidir.

\section{Yöntem}

Tarihi araştırmalar genellikle arşivlerde bulunan yazılı metinler kullanılarak yürütülmektedir. Yazılı metinler üzerinde yapılan incelemelerde sıklıkla kullanılan bir yöntem olan doküman analizi, bu araştırmanın da yöntemini oluşturmaktadır. Doküman incelemesi, araştırılması hedeflenen olgu veya olgular hakkında bilgi içeren yazılı materyallerin analizini kapsar. Nitel araştırma için doküman incelemesi tek başına bir veri toplama yöntemi olarak kullanılabilir (Yıldırım ve Şimşek, 2011).

Yapılandırmacılık, eğitim-öğretim ortamında okul-öğrenci-öğretmen paydaşlarının uyum içinde çalışmasını gerektiren bir eğitim stratejisidir. Yapılandırmacı öğrenme yaklaşımının uygulanabilmesi için bu üç paydanın her biri gereklidir. Bu çalışmada yapılacak olan, Salih Zeki tarafından yazılmış olan ders kitaplarının bu yaklaşıma uygun yazılıp yazılmadığını tespit etmektir. Yapılandırmacılığın temel özelliklerinden yola çıkarak, bir ders kitabının yapılandırmacı karakter taşıyıp taşımadığını tespit etmek için bir takım temel kriterlere ihtiyaç vardır. Alanyazın taranarak ve uzman görüşleri alınarak hazırlanan bu kriterler 11 maddede şu şekilde gruplandırılabilir:

1. Bilgi öğrencinin zihninde inşa edilerek, öğrenci anlamlı öğrenmeye yöneltilebilmiş midir? (MEB, 2009b; Özgen ve Alkan, 2012)

2. Matematiksel kavramlar arasında ilişkilendirme yapılmış mıdır? (MEB, 2009a; MEB, 2009b; MEB, 2013)

3. Eski bilgiler harekete geçirilerek yeni bilgiler ile ilişkilendirilmesi sağlanmış mıdır? (Bukova-Güzel, 2008; MEB, 2009b)

4. Matematiksel kavramlar kitapta, öğrencilerin somut deneyimlerinden ve sezgilerinden matematiksel anlamları oluşturacak biçimde yer almış mıdır? (MEB, 2009a; MEB, 2013)

5. Kitapta problem çözme yöntemine yer verilmiş midir? (Özgen ve Alkan, 2012) 
6. Matematik konuları ile gerçek yaşam arasında ilişkilendirme yapılııı̧ mıdır? (Arkün ve Aşkar, 2010; Bukova-Güzel, 2008; MEB, 2009b; MEB, 2013)

7. Kitap, bilginin inşa edilmesinde öğrenciye gerekli malzemeyi ve bilişsel ortamı sağlamış mıdır? (Baki, 2006; Delil ve Güleş, 2007; MEB, 2009b; MEB, 2013)

8. Öğrencilere üst düzey düşünme becerileri kazandıracak etkinliklere yer verilmiş midir?

9. Diğer disiplinlerle ilişki kurulmuş mudur? (MEB, 2009b)

10. İçerikte grafik, resim, şekil gibi çoklu gösterim araçlarına yer verilmiş midir? (Baki, 2006; Özgen ve Alkan, 2012)

11. Konu ile ilgili soruların alıştırma problemleri, öğrencinin muhakeme becerisini geliştirecek biçimde organize edilmiş midir?

Söz konusu kriterlerin yapılandırmacılık ile ilgili literatürden elde edilmiş olması araştırmanın güvenirliliğini artırmıştır. Dış geçerliğin sağlanması için de ders kitaplarından doğrudan alıntı yapılmıştır.

Yukarıda ifade edilen temel kriterler çerçevesinde veriler doküman analizi yöntemi ile analiz edilerek Salih Zeki'nin söz konusu geometri ders kitaplarının satır aralarında yapılandırmacı yaklaşımın izi sürülmüştür. Ders kitaplarında bu kriterlerin yer alma durumları, ders kitaplarının ne kadar yapılandırmacı karakter taşıdıkları hususunda bilgi verecektir. Ders kitapları araştırmacı tarafından Osmanlıca'dan Türkçe'ye (Arap harflerinden Latin harflerine) translite edilmiştir.

\section{Bulgular}

Çalışmanın bu bölümünde, belirlenen kriterler çerçevesinde analiz edilen 6 adet geometri ders kitabından elde edilen bulgular paylaşılacaktır. Salih Zeki İlk Hendese Dersleri Birinci Sene isimli ders kitabının girişinde, dersi okutacak olan öğretmenlere hitaben bir uyarı yazısı kaleme almıştır. Bu yazıda, dersin öğretiminde kullanılacak olan yöntem ve stratejileri belirtmektedir:

\section{Öğretmenlere: Uyarı}

Bu kitap geometriye yeni başlayan çocukların ellerinde bulunacak ve fakat içindeki konular (mevâdd) ezberlettirilmeksizin çocuklara anlattırılacaktır. Birinci bölümün konuları sınıfta, bahçede, kısaca her yerde çocuklara yavaş yavaş gösterilecek ve ikinci bölümün bununla ilgili olan uygulamaları da hemen beraberce yaptırılacaktır. Çocukların bulunduğu okulda birkaç cetvel ve pergel, hatta ucuna tebeşir takılır tahta bir pergel ile kâfi miktarda kurşun kalem, birkaç gönye, en az bir açıölçer bulunmadıkça nafile yere geometri öğretmeye kalkışmamalıdır. Çocuklara hiçbir zaman tarifler ezberlettirilmemeli; bilakis şekiller yapdırılarak bu tarifler kendilerine buldurulmalıdır (Zeki, 1332/1914a, s. 2).

Salih Zeki kitabının önsözünde geometri öğretimine yönelik tavsiyelerde bulunmuş olması, onun sadece matematikçi değil aynı zamanda eğitimci olduğunu da göstermektedir. Uyarısının birinci paragrafinda, öğrencilere herhangi bir bilginin kesinlikle ezberlettirilmemesini, öğrencinin bilgiyi inşa etmesini sağlayacak eğitim öğretim ortamlarının oluşturulmasını istemiştir. İkinci paragrafta ise, öğrencilere herhangi bir tanımın veya kuralın ezberlettirilmemesini, daha ziyade bir takım şekiller yaptırılarak söz konusu tanımın ya da kuralın buldurulmasının gerekliliğini bildirmiştir. Bu anlamda Salih Zeki, günümüzde buluş yoluyla öğrenme stratejisi olarak bilinen yöntemi, o dönemin öğrencilerinin matematik eğitiminde uygulamayı düşünmüştür. Ayrıca okullarda, matematik öğretimi için gerekli olan bazı araç gereçlerin bulunması gerektiğini de bildirmiştir. Salih Zeki'nin matematik öğretmenlerine yönelik kaleme aldığı bu uyarı yazısı; yazarın matematik eğitiminde uyguladı̆̆ yöntem ve teknikleri bilinçli bir şekilde seçmekte olduğunu göstermektedir.

Salih Zeki'ye ait 6 geometri ders kitabı, araştırma için belirlenen 11 kriter çerçevesinde incelenmiştir.

\subsection{Ders Kitaplarında Yapılandırmacı Karakter Taşıyan Örnekler}

\subsubsection{Bilgi ögrencinin zihninde inşa edilerek, ögrrenci anlaml öğrenmeye yöneltilebilmiş midir?}

$\mathrm{Bu}$ bölümde, Salih Zeki’nin kaleme almış olduğu 6 geometri ders kitabında ilk kriter olarak bilginin öğrencinin zihninde inşa edilmesine uygun olacak şekilde bir anlatım gerçekleşip gerçekleşmediği analiz edilmiştir. Örneğin Hendese-i Tecrubiyye kitabına Salih Zeki, "ta 'rifâtt" yani tanımlar ile başlamıştır:

Ölçülebilen şeyler 3 çeşittir. Bunlar, uzunluk, alan ve hacimdir. Örneğin, 'Bu sınıfın bir ucundan diğer ucuna kadar olan mesafe kaç metredir?' biçiminde bir soru yöneltilse amaç uzunluk ölçmek olur. 'Bu sınıfın zeminine, bir kenarı 1 metre olan kare şeklindeki mermerlerden kaç tane döşenebilir?' biçiminde bir soru yöneltilse amaç alan ölçmektir. 'Bu sınıfın içine, bir kenarı 1 metre olan küplerden en fazla kaç tane sığar?' biçiminde bir soru sorulsa amaç hacim ölçmektir (Zeki, 1327/1909, s. 3-4). 
Yazar, tanımlamaları salt kitabî bilgiler ile değil örnek durumlar ile inşa etmeye çalışmıştır. Amaç öğrencinin tanımları özümsemesini sağlamaktır. Alan ve hacim için bir kavramın inşasının önemsenmediği bir bakışta, "Bir dikdörtgenin alanı iki kenarının çarpımıyla bulunur... Dikdörtgenler prizmasının hacmi taban alanı ile yüksekliğinin çarpımıdır... Hacim = Taban alanı x Yükseklik ...” vb. gibi ifadeler yer alır. Oysaki Hendese-i Tecrubiyye kitabında alan ve hacim konusu ile ilgili verilen örnek durumlar, bu kavramların matematiksel açıdan "asıl anlamlarına" ulaşma hedefindedir. Formülden ve kuraldan uzak, kavramın özünü açıklamaya çalışan bir yaklaşım benimsenmiştir. "Bu sınıfın zeminine, bir kenarı 1 metre olan kare şeklindeki mermerlerden kaç tane döşenebilir?" sorusu alan kavramına ulaştıracak önemli bir örnek durumu ifade etmektedir. Tanımlar bölümünde yer alan diğer kavramlar için de benzer yaklaşımlar benimsenmiştir. Örneğin;

Alan, herhangi bir şeyin yüzeyidir. ... Üç tür alan vardır. Bazı alanlar vardır ki bir cetvel tahtası o alana her noktada değer. Bir masanın üzeri gibi. Bu alanlara düzgün alanlar denir. ...Bazı alanlar vardır ki bu alanlara bir cetvel tahtası bir yönde tamamen değer iken diğer bir yönde sadece bir noktada değer. Mesela bir su borusunun yanal alanı gibi. Bu alanlara ĕgri alanlar denir. ...Bazı alanlar vardır ki bir cetvel tahtası her yönde ancak bir noktada değer. Bir yumurtanın yüzey alanı gibi. Bu alanlara yuvarlak alanlar denir (Zeki, 1327/1909, s. 6-7).

Tanımlar bölümündeki bu noktayı, kavramların inşa edilmesi açısından, yapılandırmacılık yaklaşımının ilk işareti olarak düşünebiliriz. Salih Zeki kitabın bu bölümünde; uzunluk, alan, hacim, uzunluk çeşitleri, alan çeşitleri, hacim çeşitleri kavramlarını inşa etmiştir.

Hendese-i Tecrubiyye kitabının ikinci kısmında daha ayrıntılı bir biçimde, temel özellikleri ilk derste verilen uzunluk ve uzunluk ölçme konularına değinilmiştir. Uzunluk ölçümü şu şekilde açıklanmıştır:

"Bir şeyin uzunluğunu ölçmek, o şeyde herkesçe bilinen başka bir şeyden kaç tane olduğunu bulmak demektir. Herkesçe bilinen şeye karşılaştırma birimi veya birim denir. Mesela bu sınıfın uzunluğunu ölçmek, bu uzunlukta metre dediğimiz uzunluktan kaç tane olduğunu bulmak demektir (Zeki, 1327/1909, s. 13).”

Bu cümlede yer alan "bir şeyin içinde herkesçe bilinen bir şeyden kaç tane olduğu” sorgulaması bizi birim kavramının kökenine götürmektedir. Herhangi bir ölçüm yapmak için karşılaştırılabilecek bir şeyin olmasının gerekliliği ifade edilmektedir. Bu sayede öğrenciye; kilometre, metre, santimetre, gibi uzunluk ölçü birimlerinin mutlak ölçüm birimleri olmadıkları, evrensel bir uzunluk kabulü oldukları, bunların dışında da uzunluk ölçü birimleri oluşturulabileceği hissettirilmektedir. Bu düşünsel zemin ileride ifade edilecek olan alan ve hacim hesaplamalarına kaynaklık edecektir.

Salih Zeki diğer kitaplarında da tanımları ve kavramları bu yaklaşıma sadık kalacak şekilde açıklamıştır. Örneğin Illk Hendese Dersleri, Devre-i Âliye Íkinci Sene kitabında eş yüzeylerle ilgili şu açıklamayı yapmıştır:

"Bir yüzeyin her bir noktası tamamen diğer bir yüzeyin her noktasına çakışık (müntabık) olursa bu yüzeylere birbirlerine eş yüzeyler denir (Zeki ve Hâki, 1332/1914, s. 4).”

Salih Zeki Hendese-i Tecrubiyye kitabında alan konusuna girmeden dikdörtgen ve kare tanımlarını inşa faaliyetine devam ederek şu şekilde vermiştir:

Elimize basit bir kâğıt alırsak dört köşesinde bulunan açıların birer dik açı olduğunu görürüz. Bundan başka kâğıdın dört kenarının da birbirine eşit olduğu ve ikisinin büyük, diğer ikisinin de küçük olduğunu herhangi bir tecrübemizle biliriz. Fakat bunlardan büyükleri birbirine eşit olduğu gibi küçük kenarlar da birbirine eşittir. Bunu anlamak için kâğıtları bir kere enince bir kere de boyunca bükecek olur isek birincide büyük kenarların ikincide küçük kenarların eşit olduğu ortaya çıkar. İşte böyle basit bir kâğıt gibi dört açısı da dik açı olan ve yalnız karşı karşıya bulunan kenarları birbirine eşit olan dört kenarlı şekle geometri de dikdörtgen denir. Şimdi o kâğıdı bir de büyük kenarı, küçük kenarlardan birinin üstüne gelecek biçimde köşegen boyunca bükelim. Bu halde kâğıdın boyunda bir parça fazlalık oluşur. Bir makas ile bu fazlalığı kaldırır ve kâğ masa üzerine açarsak bu sefer açıları dik olan ve dörtkenarı birbirine eşit olan bir şekil meydana gelir. İşte bu şekildeki gibi dört kenarı birbirine eşit olan ve açıları dik açı olan şekle de geometride kare denir. Her kenarının boyu 1 metreye eşit olan bir karenin alanı da bir metre kare biçiminde ifade edilir (Zeki, 1327/1909, s. 48-50).

Günlük hayatta kullandığımız bir A4 kâğıdından yola çıkarak dikdörtgen ve kare tanımları yapılmıştır. Bilindik bir örnekten yola çıkılarak yapılan tanım, yeni öğrenilecek bir kavramın zihinde oluşturulmasını kolaylaştırmaktadır. Dikdörtgenden yola çıkarak kare tanımının yapılması, her karenin aynı zamanda dikdörtgen olduğunu da hissettirmektedir. Aynı paragraf içerisinde birim kare tanımının yapılması da daha sonra geçiş yapılacak olan alan kavramının temelini teşkil etmesi açısından inşa faaliyetinin devam ettiğini göstermektedir. Parçaların bir araya getirilerek bir yapının oluşturulması anlamında kullanılan yapısalcılık (Baki, 2006) kitabın bu bölümünde karşılık bulmaktadır. 
Davranışçı yaklaşımda alan ölçü birimleri arasındaki dönüşümler (1 metrekare $=100$ desimetrekare $=$ 10000 santimetrekare ... gibi) bir tabloda maddeler halinde verilir. Hendese-i Tecrubiyye kitabında ise bu dönüşümler şu şekilde izah edilmektedir:

\begin{abstract}
...Şimdi siyah tahta üzerine bir kenarı 1 metre olmak üzere bir kare çizelim. Bu karenin her kenarını onar eşit parçaya ayıralım. Sonra da karşı karşıya bulunan noktaları doğru parçaları ile birleştirelim. Bu halde tahta üzerine çizmiş olduğumuz kareyi bir takım küçük karelere ayırmış oluruz. Bu karelerin her birinin kenarları 1 desimetreye eşit bulunur. İşte kenarı 1 desimetreye eşit olan bu gibi karelere de desimetrekare denir. Acaba daha önce tahta üzerine çizdiğimiz metrekarenin içinde böyle kaç desimetrekare vardır? Bunu bulmak için önce büyük karenin bir kenarı hizasınca kaç tane küçük kare olduğunu sayalım: on tane desimetrekare olduğunu buluruz. Bundan anlarız ki büyük karenin içinde birbiri üzerinde on sıra var ve her sırada da on tane küçük kare vardır. O halde bütün kare içinde $10 \times 10=100$ kare bulunması gerekir. Demek oluyor ki 1 metrekarede yani kenar1 1 metre veya 10 desimetre olan bir karede 100 desimetrekare vardır (Zeki, $1327 / 1909$, s. 50-51).
\end{abstract}

Davranışçı yöntemde, alan ölçü birimleri yüzer yüzer büyüyüp küçülür biçiminde ezberletilerek öğretilen bilgi burada modellenerek ifade edilmiştir. Aynı model kitabın ilerleyen bölümlerinde santimetrekare ve milimetrekare için de tekrarlanarak alan ölçü birimlerinin, öğrencilerin zihinlerinde bütünleşmesine imkân sağlamıştır. Ayrıca yukarıdaki paragrafta yer alan "Acaba daha önce tahta üzerine çizdiğimiz metrekarenin içinde böyle kaç desimetrekare vardır?" sorusu geometrik şekillerde yüzey alanının nasıl bulunacağını da hissettirmektedir. $\mathrm{Bu}$ açıdan bir sonraki konu için inşa faaliyetinin devam ettiğini görmekteyiz. Hendese-i Tecrubiyye kitabının bu bölümünde şu cümle alan kavramını açıklamaktadır:

“İşte bir alanı ölçmek demek o alanda kaç tane metrekare veya kaç tane desimetrekare veyahut kaç tane santimetrekare olduğunu bulmak demektir (Zeki, 1327/1909, s. 52).”

Alan kavramına dair bir diğer tanım Illk Hendese Dersleri, Birinci Sene kitabında şu şekilde izah edilmiştir:

Bir alanı ölçmek demek, birim alan (vahid-i kıyâsi) olarak kabul edilen bir alanın, bu alanda kaç defa olduğunu arayıp bulmak demektir. Alanlar için genellikle kabul edilen birim alan, eni ve boyu bir metre olan bir karenin alanıdır ki buna metrekare denir. ... İşte bir alan, bir metrekareden kaç tanesini alabiliyorsa, o alana o kadar metrekaredir denir (Zeki \& Hâkî, 1334/1915, s. 65).

Yapılandırmacılık bireyin bilgiye nasıl ulaştığını, bu süreçleri nasıl geliştirdiğini ve kullandığını açıklar (Gömleksiz ve Kan, 2007). İlk Hendese Dersleri kitabında alan kavramı, daha önce Hendese-i Tecrubiyye kitabında da olduğu gibi, "Bir alanı ölçmek demek, birim alan olarak kabul edilen bir alanın, bu alanda kaç defa olduğunu arayıp bulmak demektir." biçiminde genel bir tanım ile ifade edilmiş ve tüm alan hesaplamaları bu kavram üzerine inşa edilmiştir.

Hendese-i Tecrubiyye kitabında tek bir cümleyle oluşturulan alan kavramı önce inşa edilmiş, sonra kurallaştırılmıştır. Daha sonra alan ile ilgili şu açıklamaya yer verilmiştir:

Elimize bir santimetre eninde iki santimetre boyunda bir takım domino taşları alır ve ortalarından ikiye bölersek bir kenarı 1 santimetre olan birçok kare elde etmiş oluruz. Bu karelerden her biri önceki derslerde gördüğümüz gibi 1 santimetrekareden ibarettir. Bu küçük karelerden dört tanesini alarak birbiri ardı sıra dizelim. Bu halde bir dikdörtgen elde etmiş oluruz ki bu dikdörtgenin alanı 4 santimetrekare toplamına eşit olur. Çünkü yalnız bir sıra olduğundan onda da dört tane santimetrekare bulunduğundan şüphesiz ki toplamı $1 x 4=4$ santimetrekare olur. Şimdi bu sıranın altına dört yarım domino taşı daha koyarak bir ikinci sıra ilave edelim. Ortaya çıkan şekil yine bir dikdörtgen olur. Fakat bu dikdörtgende 2 sira olduğundan ve her sirada 4 santimetrekare bulunduğundan alanı toplam $2 \times 4=8$ santimetrekareden ibarettir. ... İşte şu birkaç örnekte görülüyor ki bir dikdörtgenin alanını ölçmek yani kaç santimetrekareye eşit olduğunu bulmak için büyük ve küçük kenarlarda kaçar tane santimetre olduğunu aramak ve sonra da bulunan 2 sayıyı birbiri ile çarpmak gerekir. Bir dikdörtgenin alanını bulmak için yaptığımız bu işe dikdörtgenin enini boyuna çarpmak denilir ki bunda amaç eniyle boyu ayrı ayrı ölçülerek kaçar santimetre bulunur ise o sayıları birbiri ile çarpmaktır. Böylece elde edilen sonuç o dikdörtgende kaç santimetrekare olduğunu gösterir (Zeki, 1327/1909, s. 52-53).

Bir dikdörtgenin alanının nasıl hesaplandığının açıklandığı bu paragrafta, küçük karelerden büyük dikdörtgenler oluşturularak tümevarım yönteminin benimsendiği görülmektedir. Alan kavramı, özüne uygun olarak öğrencinin zihninde parça parça inşa edilmiştir.

Dairenin çevresi ve alanı konusu öğrencilerin öğrenmekte zorlandıkları konuların başında gelmektedir. Çoğu öğrenci hayatında ilk defa bu konu münasebetiyle $\pi$ sayısını duymaktadır. Yalnız öğrencilere bu sayının; $\pi=3,1416$ olduğu ve çemberin çevresinin uzunluğu ile dairenin alanının hesaplanmasında kullanılan sabit bir 
sayı olduğu söylenirse, öğrenciler bu bilgiyi sadece uygulama düzeyindeki sorularda, formülün yerine ilgili sayıları yazmak suretiyle kullanmaktan başka bir şey yapamayacaklardır. Buna karşın Salih Zeki, $\pi$ sayısı ile çemberin çevresi arasındaki ilişkiyi İlk Hendese Dersleri, Devre-i Âliye İkinci Sene isimli kitabında şu şekilde açıklamaktadır:

...Eğri çizgilerin en düzgünü dairenin çevresidir. ...Bir takım hesaplamalar ve birçok çalışmalar neticesinde, her daire çevresinin kendi çapından 3,1416 adet kere büyük olduğu bulunmuştur. Yani bir dairenin çevresinin ne uzunlukta olduğunu anlamak için, ilk önce o dairenin çapı ölçülmeli, sonra bulunan değer 3,1416 sayısı ile çarpılmalıdır. Bu miktar sabittir. Yunanca $\pi$ harfi ile gösterilir ve pi şeklinde okunur. Demek ki; dairenin çevresi $=$ çap $\times \pi$ 'dir (Zeki ve Hâki, 1332/1914, s. 12).

$\pi$ sayısının ne anlama geldiğinin ve nereden ortaya çıktığının açıklandığı yukarıdaki paragrafta, dairenin çevresi ile $\pi$ sayısının doğası gereği kurulan ilişkinin ortaya konulması, anlamlı öğrenmeye uygun olarak dairenin çevresinin öğrencinin zihninde inşa edilmesine imkân sağlamıştır. Ayrıca İlk Hendese Dersleri, Devre-i Mutavassıta İkinci Kitap kitabında da $\pi$ sayısı benzer bir yaklaşımla şu şekilde ele alınmıştır:

Dairenin çevresi: Bir daireyi açtığınız zaman ne uzunlukta olduğunu bulmak için çapını 3,1416 sayısıyla çarpmak gerekir. Bu 3,1416 sayısı bir daire çevresinin çapına oranından çıkan sonuçtur. Bu sayı tüm daireler için geçerlidir, değişmez. ...Mesela yuvarlak bir ağacın çevresi 2,40 metre olsa çapı ne olur? Bir ağacın çapını bulmak için ip ile ölçtüğümüz çevreyi 3,1416 sayısına böleriz. $\frac{2,40}{3,1416}=0,76$ metre buluruz (Zeki, 1332/1914b, s. 10).

Hacim konusunda da tıpkı alan hesabında olduğu gibi inşa faaliyetine devam eden Salih Zeki hacim kavramını Ilk Hendese Dersleri, Devre-i Âliye İkinci Sene isimli kitabında şu şekilde tanımlamıştır:

"Herhangi bir cismin hacmini ölçmek demek, o cisimde hacimler için, [karşılaştırmak amacıyla] birim olarak kabul edilen (vâhid-i kıyâsî) hacmin kaç defa bulunduğunu arayıp bulmak demektir. ...Hacim için birim metreküptür (Zeki ve Hâki, 1332/1914, s. 32).”

İlk Hendese Dersleri kitabında alan konusu için yapılan inşa faaliyeti, yukarıda ifade edilen genel hacim tanımına uygun olarak, geometrik cisimlerin hacimleri için de kurgulanmıştır. Örneğin dikdörtgenler prizmasının hacmi şu şekilde anlatılmıştır:

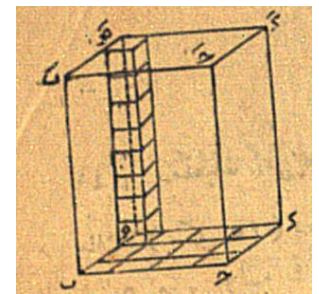

Şekil 1

Bir dikdörtgenler prizmasının hacmi, üç uzunluğunun [en, boy, yükseklik] birbirleriyle çarpımına eşittir. Mesela Şekil 1'de görülen dikdörtgenler prizmasının tabanının uzunluğu $B C$, eni $H E$ ve bu prizmanın yüksekliği de $C C^{\prime}$ olsun. Bu durumda hacmi $C C^{l} \times B C \times H E$ olur. Örneğin; taban uzunluğu $B C=4$ metre, eni $H E=3$ metre, yüksekliği $C C^{l}=8$ metre olsa, prizmanın hacmi $4 \times 3 \times 8=96$ metreküp olur. [Bu durum şu şekilde ispatlanabilir] Bu dikdörtgenler prizmasının tabanı $4 \times 3=12$ metrekareye eşittir. Şimdi 12 adet metrekare üzerine birer metreküp konulsa bir metre yüksekliğinde olmak üzere bir tabaka yani bir kat dikdörtgenler prizması vücuda getirilmiş olur. Diğer bir deyişle, taban alanı 12 metrekare ve yüksekliği 1 metre olan bu katta 12 tane küp bulunur. Fakat bu dikdörtgenler prizmasının yüksekliği 8 metre olduğundan bu tabakanın üzerine daha böyle 7 tabaka istif edilebilir. Bütün dikdörtgenler prizması ise böyle 8 tabakaya eşit olabileceğinden ve her bir tabakada $4 \times 3=12$ metrekare bulunacağından toplam küplerin adedi $4 \times 3 \times 8=96$ olur... Bu durumda bir dikdörtgenler prizmasının hacmi şu şekilde de ifade edilebilir; bir dikdörtgenler prizmasının hacmi, taban alanı ile yüksekliğinin çarpımına eşittir (Zeki ve Hâki, 1332/1914, s. 32-33).

Salih Zeki bu anlatımda, salt matematiksel bir formülün oluşturduğu zihinsel kıskaçtan öğrenciyi kurtararak, onun zihninde hacim kavramının oluşmasını sağlamıştır. Yazar bu amaçla konuyu görsel unsurlar ile desteklemiştir. Oysa "matematiğin zihinde inşası" düşüncesine sahip olmayan bir ders kitabında bu konu sadece "bir dikdörtgenler prizmasının hacmi, taban alanı ile yüksekliğinin çarpımına eşittir" tanımlamasıyla sınırlı kalacaktır. 
Salih Zeki Nazarî ve 'Amelî Mücmel Hendese kitabında "bir doğru üzerindeki noktadan sadece bir dik doğru çizilebilir" önermesini şu şekilde inşa etmiştir:

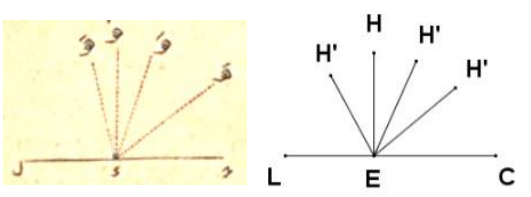

Şekil 2

Örneğin $L C$ (Şekil 2) doğrusunun $E$ noktasından bu doğruya $E H$ gibi yalnız bir dikme resmedilebilir. Çünkü $E H$ doğrusunu, önce $E C$ doğrusu üzerine çakışık varsayalım ve $E$ noktası etrafinda sağdan sola doğru döndürelim. Bu döndürme hareketine devam edildikçe sağ tarafinda hâsıl olan açı daima büyüyeceği gibi sol tarafta hâsıl olan açı da küçülür. İşte $E$ noktası etrafında döndürülen bu $E H^{\prime}$ doğrusu, $E H$ gibi bir vaziyete gelir ki bu vaziyette her iki tarafinda yani sağ ve solunda hâsıl olan açılar birbirlerine eşit olur. Binaen aleyh bu vaziyette $E H$ doğrusu $L C$ doğrusuna dik bulunur. Bu vaziyetten ne şekilde olur ise olsun, küçük bir hareket edilecek olsa iki tarafında hâsıl olan açılar arasındaki eşitlik bozulacağından $E H^{\prime}$ doğrusu da $L C$ doğrusuna dik olamaz. Bundan anlaşılır ki $L C$ doğrusunun $E$ gibi bir noktasından bu doğruya yalnız bir $E H$ dikmesi çizilebilir; birden fazla olamaz (Zeki, 1322/1904, s. 17-18).

Bir doğruya, üzerindeki bir noktadan ancak bir dik doğru çizilebilir önermesi için verilen açıklama, öğrencinin bu önermeyi zihninde oluşturabileceği niteliktedir. Tek bir cümlede verilebilecek bir kural, işlem basamakları ayrıntılı bir şekilde uzun uzun açıklanarak anlamlı öğrenme ortamı oluşturulmaya çalışılmıştır.

Salih Zeki açı değerini "derece" cinsinden vermek yerine, sadece "dik açı" cinsinden ifade etmiştir. Bu durum, geometri ile yeni tanışan öğrencilerin zihinlerinde açı kavramının dereceden bağımsız bir şekilde yerleşmesine imkân sağlayacaktır. Aksi takdirde öğrenci, dik açının sadece 90 derece ile ifade edilebileceği yanılgısına düşebilecektir (Zeki, 1322/1904, s. 19-21).

\subsubsection{Matematiksel kavramlar arasında ilişkilendirme yapılmış mıdır?}

Matematiksel kavramlar birbirleriyle ilişkilendirildiklerinde matematiğin dünyası çok daha anlaşılır olacaktır. Bu bölümde Salih Zeki’ye ait 6 adet ders kitabında matematiksel kavramlar arasında ilişki olup olmadığ incelenmiştir.

Salih Zeki'nin İk Hendese Dersleri, Devre-i Âliye İkinci Sene isimli ders kitabının kronolojik sırasında dikdörtgenin alanı, karenin alanı ve paralelkenarın alanı anlatıldıktan sonra sıradaki konu üçgenin alanıdır. Davranışçı strateji ile hazırlanmış klasik bir ders kitabında bu biçimde bir konu sıralaması takip edilmez. Kenar sayısına paralel bir biçimde, önce üçgenin alanı daha sonra dikdörtgenin ve karenin alanı anlatılır. Ancak bunlardan sonra paralelkenar, eşkenar dörtgen ve yamuk gibi nispeten daha özelleşmiş şekillerin alanları anlatılır. Bu kitapta, dikdörtgenin, karenin ve paralelkenarın alanı üçgenin alanı ile şu şekilde ilişkilendirilmiştir:

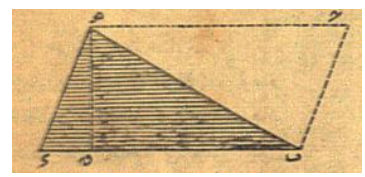

Şekil 3

Bir üçgenin alanı, tabanının yüksekliğine çarpımının yarısına eşittir. [Bu kuralın ispatı şu şekilde yapılabilir] Şekil 3'den de anlaşılacağı gibi $B H E$ üçgeni, $B C H E$ paralelkenarının tam yarısıdır. $B C H E$ paralelkenarının alanı ise, $B E$ tabanının $H G$ yüksekliği ile çarpımına eşittir. Dolayısıyla bu paralelkenarın yarısına eşit olan $B H E$ üçgeninin alanı da daha önce elde edilmiş olan $|B E| x|H G|$ çarpımının yarısına eşit olması gerekir (Zeki ve Hâki, 1332/1914, s. 7-8).

Üçgenin alanının nasıl hesaplanacağının bulunmuş olması, alanı üçgenlere ayrılabilen tüm şekillerin alanlarının da hesaplanabilmesi anlamına gelmektedir. Nitekim bunun ilk örneği yamuğun alanında karşımıza çıkmaktadır: 


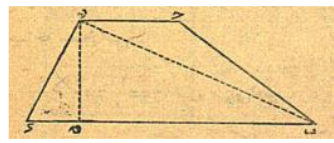

Şekil 4

Yamuğun alanı, iki tabanı toplamının yüksekliğine çarpımının yarısına eşittir. Şekil 4'deki gibi $B C H E$ yamuğunu, $H B$ köşegeni ile $B C H$ ve $B H E$ gibi üçgenlere ayırırsak, yamuğun alanı, bu iki üçgenin alanının toplamına eşit olacağını görürüz ki bu yöntem yukarıdaki kuralın doğruluğunu ispatlamaktadır (Zeki ve Hâki, 1332/1914, s. 8-9).

Üçgenin alanı kullanılarak alanı hesaplanan bir diğer şekil düzgün çokgendir. Düzgün çokgenler eş üçgenlere ayrılarak alanları hesaplanabilmektedir. Matematiksel şekillerin alan konusundaki kavramsal ilişkisi, düzgün çokgenin alanı bahsinde de karşımıza çıkmaktadır:

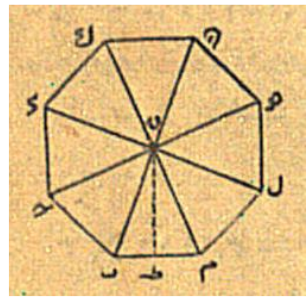

Şekil 5

Bir düzgün çokgenin alanı, çevresinin yüksekliğine çarpımının yarısına eşittir... [Bu kaide şu şekilde ispatlanmaktadır] Bu şeklin [Şekilde gösterilen MLHNKECB gibi bir sekiz kenarlı düzgün çokgenin] bütün yarıçap üçgenlerini çizsek, sekiz tane birbirine eş ikizkenar üçgenler meydana gelir (Şekil 5). Bunlardan birinin, örneğin $F M B$ üçgeninin alanı, $\frac{|M B| x|F T|}{2}$, yani $\frac{2 \times 3}{2}=3$ metrekare olur. Bu düzgün şekil bunun gibi sekiz üçgenden oluştuğundan çokgenin alanı, $8 \times 3=24$ metrekare olur (Zeki ve Hâki, 1332/1914, s. 11-12).

Öğrencinin zihninde alan kavramı ile ilgili boşluk kalmayacak biçimde üçgenin alanı ile düzgün çokgenin alanı ilişkilendirilmiş̧ir. Dolayısıyla düzlemsel şekillerin alan bilgisinin öğrenci tarafından oluşturulması için gerekli bilişsel ortamın sağlandı̆̆ görülmektedir. Alanı, üçgenin alanı ile ilişkilendirilerek anlatılan son şekil dairedir.

Salih Zeki, Nazarî ve 'Amelî Mücmel Hendese isimli kitabında, çokgen, çember, çemberin çevresi ve $\pi$ sayısı kavramlarını ilişkilendirerek anlatmıştır. Salih Zeki, öğrenciler için anlaşılması çok kolay olmayan çemberin çevresi ve dairenin alanı bağıntılarını, seviyelerine uygun bir şekilde ispatlayarak anlatmıştır. Salih Zeki, bu bağıntılarda kullanılan $\pi$ sabit değerinin nasıl oluştuğunu tümevarım prensibini kullanarak şu şekilde anlatmıştır:
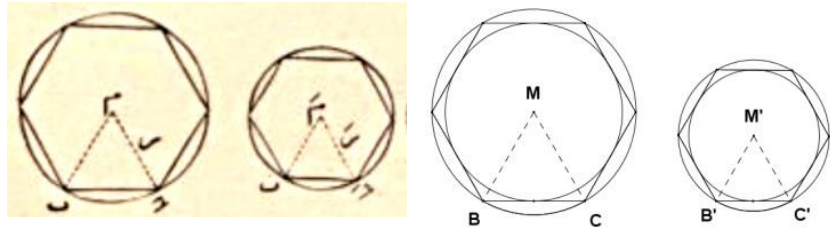

Şekil 6

Aynı kenar sayısına sahip olan iki düzgün çokgenin çevreleri arasındaki oran, bunların çevrel çemberlerin yarıçapları arasındaki orana eşittir. Mesela (Şekil 6) $M, M^{\prime}$ daireleri içine birer düzgün altıgen resmedilsin. Bu iki düzgün altıgenin kenarları toplamı, yani çevreleri sırasıyla $t, t^{\prime}$ ile ve dairelerin yarıçapları da $r, r^{\prime}$ ile ifade olunur ise $\frac{t}{t^{\prime}}=\frac{r}{r^{\prime}}$ olur. Çünkü bu iki çokgen aynı kenar sayısına sahip olduğundan [ispatlanmış olan teoreme göre] birbirine benzerdir. Dolayısıyla bunların çevreleri arasındaki oran [ispatlanmış olan teoreme göre] kenarları arasındaki orana eşittir. Diğer bir deyişle, $\frac{t}{t^{\prime}}=\frac{B C}{B^{\prime} C^{\prime}}$ olur. Hâlbuki $M$ ile $B, C$ ve $M^{\prime}$ ile $B^{\prime}, C^{\prime}$ noktaları arasında doğru parçaları çizilirse $M B C$ ve $M^{\prime} B^{\prime} C^{\prime}$ gibi iki üçgen oluşur ki bunlar da birbirine benzerdir. Şimdi bunların benzerliğinden $\frac{B C}{B^{\prime} C^{\prime}}=\frac{B M}{B^{\prime} M^{\prime}}$ veyahut $\frac{B C}{B^{\prime} C^{\prime}}=\frac{r}{r^{\prime}}$ bulunur. Yukarıdaki orantıda bu oran yerine konulursa, $\frac{t}{t^{\prime}}=\frac{r}{r^{\prime}}$ elde edilmiş olur (Zeki, 1322/1904, s. 143-144). 
Salih Zeki iki düzgün altıgenin çevreleri arasındaki oranın, bu altıgenin çevrel çemberinin yarıçapları arasındaki orana eşit olduğunu ispatladıktan sonra, sonsuz kenarlı çokgen olarak düşündüğü daireler için de aynı orantının düşünülebileceğini izah etmiştir:

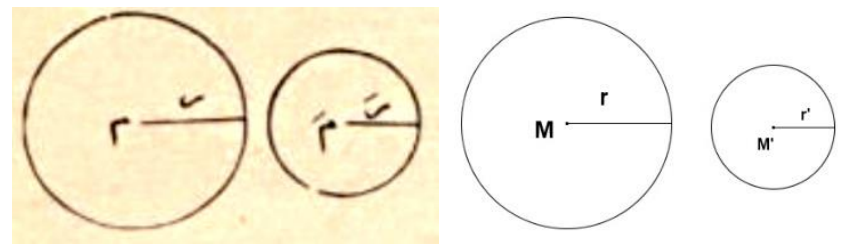

Şekil 7

İki dairenin çevreleri arasındaki oran, çapları arasındaki orana eşittir. Mesela (Şekil 7) $M, M^{\prime}$ dairelerinin çevreleri $t, t^{\prime}$ ile çapları $R, R^{\prime}$ ile ifade olunur ise, $\frac{t}{t^{\prime}}=\frac{r}{r^{\prime}}$ olur. Çünkü her iki daire de, kenar sayısı sonsuz iki benzer düzgün çokgen gibi kabul olunduğundan bunların çevreleri arasındaki oran, bir önceki teorem gereğince $r, r^{\prime}$ yarıçapları arasındaki orana eşit olur. Diğer bir deyişle $\frac{t}{t^{\prime}}=\frac{r}{r^{\prime}}$ olur. Şimdi ikinci oranın değişkenleri 2 ile çarpıldığında, $\frac{t}{t^{\prime}}=\frac{2 r}{2 r^{\prime}}=\frac{R}{R^{\prime}}$ olur ki bu da teoremi ispat eder (Zeki, 1322/1904, s. 144-145).

Salih Zeki, düzgün altıgen ile başladığı inşa faaliyetine sonsuz kenarlı çokgen olarak tanımladığı daire ile devam etmiştir. $\mathrm{Bu}$ teorem ile iki dairenin çevrelerinin oranının, çapları arasındaki orana eşit olduğunu ispatlamıştır. Bu orantıdan faydalanarak $\pi$ sayısına ulaşmıştır:

Her dairenin çevresinin çapına oranı sabit bir sayıya eşittir. Mesela (Şekil 7) $M, M^{\prime}$ dairelerinin çevreleri $t, t^{\prime}$ ve çapları da $R, R^{\prime}$ olsun. Bir önceki teorem gereğince çevreleri çapları ile orantılı olduğundan $\frac{R}{R^{\prime}}=\frac{t}{t^{\prime}}$ olur. Bu orantıda orta oranlarının yerleri değiştirilirse $\frac{t^{\prime}}{R^{\prime}}=\frac{t}{R}$ elde edilir. $\mathrm{Bu}$ eşitlik, birinci dairenin çevresinin kendi çapına oranı, ikinci dairenin çevresinin kendi çapına oranına eşit olduğunu ispat ettiğinden, her dairenin çevresinin kendi çapına oranının sabit olduğunu ifade eder. Bu sabit oran yani bir dairenin çevresi ile çapı arasındaki oran yaklaşık olarak 3,1416 sayısına eşittir. Bu oran genellikle, Yunan alfabesindeki $\pi$ harfi ile gösterilerek pi diye okunur. İşte herhangi bir dairenin çevresi ile çapı arasındaki sabit oran $\frac{t}{R}=\pi$ şeklinde ifade edilir (Zeki, 1322/1904, s. 145-146).

$\pi$ sayısı, çoğu öğrencinin rahatlıkla özümseyebildiği bir ifade değildir. 3,1416... şeklinde sonsuza kadar devam eden bir sayının nasıl ortaya çıktığının izah edilmesi, çember ve daire kavramlarının üzerine inşa edildiğ temel noktanın da açıklığa kavuşturulması demek olacaktır. $\pi$ sayısının elde edilmesinden sonra dairenin çevresi ve dairenin alanı ile ilgili bağıntıların ifade edilmesi, öğrenciler tarafından konunun özümsenmesini kolaylaştıracaktır. Nitekim Salih Zeki dairenin çevresi ile ilgili bağıntıyı öğrencilerin seviyesine uygun bir şekilde elde etmiştir:

"Bir önceki $\frac{t}{R}=\pi$ orantısından, $t=R \times \pi$ veya $R=\frac{t}{\pi}$ eşitlikleri ortaya çıkartılır. Bu eşitliklerde

$R$ çapı yerine yarıçapının iki katı yani $2 r$ yazılacak olur ise $t=2 \pi r$ ve $r=\frac{t}{2 \pi}$ ifadeleri ortaya çıkar (Zeki, 1322/1904, s. 146-147)."

Salih Zeki, dairenin çevresi ile ilgili bağıntıyı, öğrencilerin zihninde inşa edilebilecek düzeyde, matematiğin diğer kavramları ile ilişkilendirerek anlatmıştır. Öğrencilerin $\pi$ sayısı üzerine düşünmelerini sağlamış ve onun nereden ortaya çıktığını çokgen konusu ile ilişkilendirerek izah etmiştir.

\subsubsection{Eski bilgiler harekete geçirilerek yeni bilgiler ile ilişkilendirilmesi sağlanmış mıdır?}

Matematik eğitiminde eski konular ile yeni konular ilişsilendirilerek anlatıldığ 1 takdirde öğrencinin zihninde matematik bir bütün olarak inşa edilebilecektir. Bu bölümde Salih Zeki’ye ait 6 adet ders kitabında eski konular ile yeni konuların ilişkilendirilerek anlatılıp anlatılmadığı analiz edilecektir.

Salih Zeki yazmış olduğu İlk Hendese Dersleri, Devre-i Âliye İkinci Sene isimli ders kitabında silindirin hacim hesabını, öğrencinin daha önce öğrenmiş olduğu prizmanın hacim hesabından yararlanarak şu şekilde izah etmiştir: 


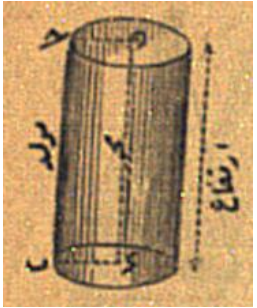

Şekil 8

Bir silindirin hacmi, taban alanı ile yüksekliğinin çarpımına eşittir. [Bu kural şu şekilde izah edilmiştir] Mesela Şekil 8'deki silindirin hacmi taban alanı $\times$ yükseklik olur. Hakikatte; silindir, yüzeyleri gayet çok ve gayet dar bir prizma gibi tasvir edilebilir. Prizmanın hacmi ise taban alanı ile yüksekliğinin çarpımına eşittir. Dolayısıyla silindirin hacmi de;

$$
\begin{gathered}
\text { Silindirin Hacmi }=\text { Taban Alanı } \times \text { Yükseklik } \\
=\pi \times(\text { Yarıçap })^{2} \times \text { Yükseklik }
\end{gathered}
$$

olur (Zeki ve Hâki, 1332/1914, s. 44-45).

Ayrıca Salih Zeki Nazarî ve 'Amelî Mücmel Hendese isimli kitabında çokgenlerin iç açılarının toplamını, kitapta daha önce bahsi geçen üçgende açı konusu ile ilişkilendirerek şu şekilde anlatmıştır:

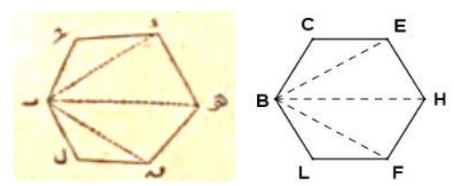

Şekil 9

Bir çokgenin iç açıları toplamı, o çokgenin kenar sayısının iki eksiği kadar iki dik açıya eşittir. Mesela (Şekil 9) $B C E H F L$ çokgeni altı kenarlı olduğu halde $B, C, E, H, F, L$ açıları toplamı $6-2=4$ defa iki dik açıya eşit olur. Zira çokgenin herhangi bir köşesi, örneğin $B$ köşesi ile çokgenin diğer köşelerini birleştirelim. Bu halde daima bir köşeye komşu iki köşe bulunacağından, çokgen kenar sayısının iki eksiği kadar üçgene ayrılabilir. Şöyle ki BCEHFL çokgeni $B C F, B E H, B H F, B F L$ gibi dört üçgene ayrılmış olur. Şimdi bu üçgenlerin açıları toplamı çokgenin iç açıları toplamına eşit olacağından, bir üçgenin üç açısı toplamı iki dik açıya eşit bulunduğundan, söz konusu çokgenin iç açıları toplamı da, 6-2=4 kadar, yani kenar sayısından iki eksik defa iki dik açıya eşit olur. İşte bir çokgenin kenar sayısı $n$ harfi ile gösterilirse, içerisinde oluşturulacak üçgenlerin sayısı $n-2$ olacağından, açıları toplamı $(n-2) \times 2$ dik açı olur (Zeki, 1322/1904, s. 51-52).

Salih Zeki'nin, çokgenlerin iç açıları toplamının nasıl bulunacağını anlatmak için üçgenleri kullanması, bu iki konu arasında gizil bulunan ilişkiyi açığa çıkarmıştır. Öğrenci, herhangi bir kurala gereksinim duymadan, kenar sayısı ne olursa olsun bir çokgenin iç açılarının toplamını hesaplayabilecektir. Salih Zeki, hemen hemen her yeni matematiksel bilgiyi, diğer matematiksel bilgilerle ilişkilendirerek anlatmaktadır. Bu yöntemle öğrenci, matematiği bir bütün olarak kavrayabilmektedir. Salih Zeki, konuyu anlattıktan sonra, söz konusu yeni bilgiyi soyutlayarak, formülleştirmeyi de ihmal etmemiştir.

Salih Zeki Nazarî ve 'Amelî Mücmel Hendese isimli kitabında prizmalardan sonra piramit cismini ele almıştır. Öncelikle piramidin temel özellikleri ifade etmiştir. Yüzey şekilleri birer çokgen olduğu için, daha önce anlatılan alan bağıntısı ile ilişki kurarak piramidin yüzey alanı bağıntısı oluşturmuştur. Piramidin hacmini ise, prizmanın hacim bağıntısı ile ilişkilendirerek şu şekilde anlatııştır:
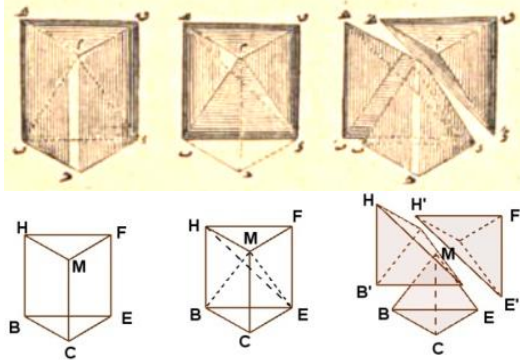

Şekil 10 
Her üçgen prizma, aynı taban ve yüksekliğe yani biri diğeri ile eş olan üç üçgen piramide ayrılabilir. Mesela (Şekil 10) BCEHMN gibi bir üçgen dik prizma varsayalım. Bu prizmayı $M B E$ noktalarından geçen bir düzlem ile keselim. Bu düzlem ile prizmadan $M B C E$ gibi bir üçgen piramit ayrılmış olur. Şimdi bir de (Şekil 10) $M H E$ düzlemi ile prizmanın geriye kalan kısmı da $M B E H, M E H F$ gibi iki üçgen piramide ayrılmış olur. Şimdi bu üç piramit birbirine eştir. Zira daha önce $M B C E, M E H F$ piramitlerini alalım: Bunların her birinin tabanı, prizmanın tabanlarından biri ve yüksekliği de prizmanın yüksekliğinden ibarettir. Diğer taraftan $M E H F, M B E H$ piramitleri de birbirine eştir. Zira bunların da tabanları $E H F, E H B$ üçgenleri olduğuna ve bu üçgenler de $B E F H$ paralelkenarının yarısından ibaret bulunduğuna göre bunlar birbirine eşittir. Yüksekliklerine gelince, o da $M$ noktasının $B E F H$ paralelkenarına olan uzaklığına eşit olduğu için ortaktır. İşte bu üç piramit aynı taban ve yüksekliğe sahip olmaları nedeniyle birbirine eştir. Bundan çıkarılır ki: Bir üçgen piramit, aynı taban ve yüksekliğe sahip bir üçgen prizmanın üçte birine eşittir. [Dolayısıyla] Bir piramidin hacmi, tabanının yüksekliğine çarpımının üçte birine eşittir (Zeki, 1322/1904, s. 202-203).

Piramidin yüzey alanı bağıntısı, bir bakışta anlaşılabilir bir bağıntı iken, piramidin hacim bağıntısı bir anda anlaşılabilecek bir bağıntı değildir. Prizmanın hacmi taban alanı $\times$ yükseklik bağıntısı ile bulunurken; piramidin hacim bağıntısında neden $\frac{1}{3} \times$ taban alanı $\times$ yükseklik olduğu, $\frac{1}{3}$ katsayısının nereden geldiği gibi sorular öğrencinin zihnini karıştıran sorulardır. Salih Zeki bu karışıklığın önüne geçmek için, prizma ile piramit arasında ilişki kurarak, bir prizmanın eş üç piramide ayrılabileceğini; dolayısıyla prizmanın hacminin üçte birinin, aynı tabana ve yüksekliğe sahip bir piramidin hacmine eşit olacağını göstermiştir. Dolayısıyla piramidin hacmi öğrenci tarafından anlamlandırılmıştır.

Salih Zeki'nin Hendese-i Tecrubiyye isimli kitabında kare ve dikdörtgenin özellikleri ile paralelkenar arasında bir ilişki kurularak paralelkenarın özellikleri çıkarsanmıştır. Kurulan ilişki alan hesabı için de sürdürülmüştür:
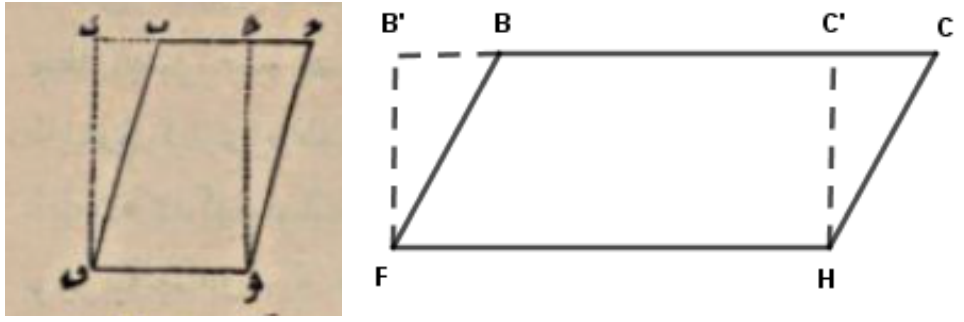

Şekil 11

Şimdi bir paralelkenarın ne olduğunu öğrendikten sonra alanının nasıl ölçüldüğüne gelelim. Bir A4 kâğıdı üzerine bir $B C H F$ paralelkenarı çizer ve kâğıdı şekildeki gibi CB hattını kendi üzerine gelecek şekilde, $\mathrm{F}$ ve $\mathrm{H}$ noktalarında iki kere bükecek olursak, $F B^{\prime}, H C^{\prime}$ gibi iki büküm doğrusu elde etmiş oluruz. Bu $F B^{\prime} H C^{\prime}$ büküm doğruları önceden verdiğimiz gibi $F H$ doğrusuna dik olduklarından, yani iki tarafta elde edilen açılar birer dik açıya eşit bulunduklarından tabidir ki elde edilen $F B^{\prime} H C^{\prime}$ şekli de bir dikdörtgen olur. Bu şekilde oluşmuş bir dikdörtgenin alanı da önceki derslerde gördügüumüz üzere $F B^{\prime}$ kenarının $H F$ kenarı ile çarpımına eşittir. Şimdi diyoruz ki; resmetmiş olduğumuz $F H C B$ paralelkenarının alanı, bulmuş olduğumuz $F B^{\prime} C^{\prime} H$ dikdörtgeninin alanına eşittir. Bunu ispat etmek çok kolaydır; evet bu iki şekle dikkat ile bakılacak olur ise görülür ki $H C^{\prime} B F$ bölgesi her ikisinde yani hem paralelkenarın hem de dikdörtgenin içinde bulunur. Paralelkenarın bundan fazlası $H C^{\prime} C$ üçgenidir. $\mathrm{O}$ zaman dikdörtgenin bundan fazlası ise $F B B^{\prime}$ üçgenidir. Bu halde paralelkenarın alanının dikdörtgenin alanına eşit olması bu iki üçgenin birbirinin aynısı olmasını gerekli kılar. Şimdi bir makas ile $C^{\prime} C H$ üçgenini çıkaralım ve bir cetvel alarak kenarını $B C^{\prime}$ kenarına yerleştirdikten sonra çıkardığımız $C^{\prime} C H$ üçgeninin $C^{\prime} C$ kenarını cetvel kenarına dayayarak ileriye doğru kaydıralım. Üçgenin $H$ noktası $F$ noktasına geldiğinde, $H C$ hattının $F B^{\prime}$ doğrusuna eşitliği bozulmayacağından, $C^{\prime}$ noktası da $B^{\prime}$ noktasına gelmiş olur. $\mathrm{Bu}$ halde şüphesiz $C^{\prime} H$ doğrusu da $B^{\prime} F$ doğrusuna paralel kalarak gelmiş olacağından, onlar da birbiri üzerine çakışmış olur. İşte bu iki üçgenin birbiri üzerine çakışmasına, alanlarının birbirine eşit olduğuna yani dikdörtgenin alanının paralelkenarın alanına eşit olduğuna hükmederiz (Zeki, 1327/1909, s. 63-64). 
Dikdörtgen ve paralelkenar şekilleri arasında kurulan ilişkinin alan hesabı konusunda da devam ettiği görülmektedir. Önceki bilgilerden yola çıkarak bir sonraki bilgi hakkında hipotezde bulunma ve bu hipotezi ispatlama yöntemi yapılandırmacılık anlayışının bir ürünüdür. Hendese-i Tecrubiyye'nin bir sonraki konusu olan bir üçgenin alanının hesaplanmasında da benzer bir hiyerarşi izlenerek, paralel kenarın alanından üçgenin alanına ulaşıldığı görülmektedir (Zeki, 1327/1909, s. 68-69).

\subsubsection{Matematiksel kavramlar kitapta, ögrencilerin somut deneyimlerinden ve sezgilerinden matematiksel anlamları oluşturacak biçimde yer almış mıdır?}

Öğrencilerin özellikle küçük yaşlarda matematiği anlamlandırabilmeleri için somut deneyimlerden yola çıkılması gerekmektedir. Bu bölümde Salih Zeki’ye ait 6 adet ders kitabında matematiksel kavramların somut deneyimlerden ve sezgilerden yola çıkılarak matematiksel anlamları oluşturacak şekilde yer alıp almadığı analiz edilecektir.

Salih Zeki Hendese-i Tecrubiyye isimli kitabında eğri çizgilerin uzunluklarının nasıl bulunacağını şu şekilde açıklamaktadır:

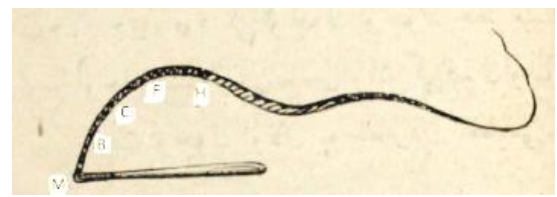

Şekil 12

...Şimdi siyah tahta üzerine eğri büğrü bir çizgi çizelim (Şekil 12). Bu çizginin üzerine metreyi koyarak uzunluğunu ölçemeyiz. Bu halde ne yapmalıyız? Böyle bir eğri çizginin uzunluğunu ölçmek için gayet kolay ve gayet doğru bir yöntem vardır ki o da ince bir iplik alarak bir ucunu hattın M ucuna bağladıktan sonra diğer ucuna kadar eğri üzerine yatırmaktan ibarettir. Eğrinin iki ucu arasında bulunan iplik gerilecek olur ise bir doğru oluşur ki bu doğrunun boyu, eğrinin uzunluğuna eşittir. Fakat ne fayda ki bu yöntemi her yerde kullanmak mümkün değildir.

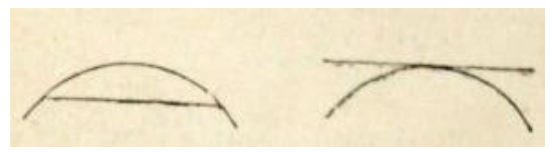

Şekil 13

İşte bunun için eğri, bir takım BM, BC, CF, FH gibi küçük küçük doğruların uç uca birleşmelerinden oluşmuş gibi kabul olunur. Gayet küçük olan bu doğrulardan bazısı eğriye 2 noktada değer ki bunlara geometride "kiriş" denir (Şekil 13). Bazısı da yalnız bir noktada değer. Bu gibi doğrulara da "teğet" denir. İşte bu küçük doğruların ayrı ayrı uzunlukları ölçüldükten sonra bu uzunluklar toplanacak olur ise bulunacak toplam yaklaşı olarak $\mathrm{MH}$ eğrisinin uzunluğuna eşit olur. Şüphesiz ki bu küçük doğrular, ne kadar kısa ve ne kadar çok olur ise, onların uzunluklarının toplamı da eğrinin uzunluğuna o kadar yaklaşmış olur (Zeki, 1327/1909, s. 89-90).

“Şüphesiz ki bu küçük doğrular, ne kadar kısa ve ne kadar çok olur ise, onların uzunluklarının toplamı da eğrinin uzunluğuna o kadar yaklaşmış olur" cümlesi, içerisinde sonsuz küçükler kavramını barındırmaktadır. Salih Zeki eğri bir çizginin uzunluğunu ölçmek için somuttan soyuta doğru ilerleyen bir yöntem benimsemiştir.

Düzgün olmayan bir eğri tanımlanıp uzunluğu ölçüldükten sonra, düzgün bir eğri olan çemberin çevre uzunluğunun nasıl bulunacağı Hendese-i Tecrubiyye kitabında şu şekilde anlatılmıştır:

...Size geçen derslerde çizmiş olduğumuz eğri büsbütün düzgün olmayan bir eğriydi. Bir takım düzgün eğriler vardır ki bunların uzunluklarını bulmak için ilave küçük küçük doğrulara ayırmaya veya üzerine iplik germeye lüzum görünmez. Bu şekilde düzgün eğriler ya bir ölçüm aleti ile veyahut doğrudan doğruya hesap yardımıyla bulunur. İşte bu eğrilerin en sadesi "çember" denilen eğridir. Şimdi bir parça iplik alalım. Bu ipliğin ucunu siyah tahtanın $M$ ucuna bir çivi ile bağlayalım veya parmak vasıtasıyla tutalım. Diğer ucuna da bir tebeşir takalım. Bu halde tebeşiri gergin tutarak ve tebeşiri tahta üzerinde gezdirerek bir eğri çizelim. Bu surette çizdiğimiz eğri yuvarlak bir eğridir ki geometride bu eğrinin alanına "daire" ve kendisine "çember", M noktasına "merkez" ve sicimin kendisine "yarıçap" ve uzunluğun 2 misline "çap" denir. İşte görüyoruz ki bu eğrinin her noktası, M merkezinden daima sicimin uzunluğuna eşit mesafede bulunur. Bu halde çember, dairenin merkezinden eşit mesafede bulunan bir eğri çizgiden ibarettir diye tanımlanabilir. $\mathrm{Bu}$ çemberin yarıçapı bulunacak olur ise bundan çemberin uzunluğunu bulmak mümkündür. Şimdi daireyi çizdikten sonra sicimi alarak... (Kitabın 2 ayrı baskısında da bu cümle tam bu noktada 
yarıda kalmıştır) $\mathrm{Bu}$ halde bir çemberin çevresi $\pi$ sayısının çapa veya yarıçapın 2 katı ile çarpımına eşittir. Bir başka ifadeyle, yarıçap $\mathrm{r}$ ile gösterilirse; çemberin çevresi $=\pi \times 2 r$ olur (Zeki, 1327/1909, s. 93-94).

Çemberin çevre hesabı anlatılmadan önce çemberin tanımının yapıldığı, elemanlarının özelliklerinin belirtildiği, çember ile dairenin ayrımına dikkat çekildiği ve çemberin somut bir şekilde çizdirildiğ görülmektedir.

Salih Zeki, Illk Hendese Dersleri, Devre-i Âliye İkinci Sene isimli ders kitabında bir yüzey alanının herhangi bir kenarı etrafında döndürülmesi ile oluşan cisimlerin incelendiği ve kitapta "müdevver cisimler" olarak isimlendirilen konuları içermektedir. Bunlardan ilki; "bir dikdörtgenin kenarlarından biri etrafında dolandırılması ile elde edilen cisim olan silindir” konusudur. Kitapta, öğrencinin söz konusu şekli zihninde canlandırabilmesi için "minare gövdesi, soba borusu, saç soba" gibi, dönem çocuklarının günlük hayatta rahatlıkla rastlayabileceği somut örnekler verilmiştir (Zeki ve Hâki, 1332/1914, s. 42). Dolayısıyla matematiksel kavramların günlük yaşamla ilişkisi kurulmuştur.

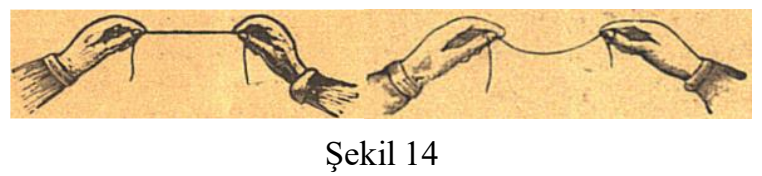

Salih Zeki'nin Illk Hendese Dersleri Birinci Sene isimli ders kitabında, düz çizgi (doğru) ile eğri çizgi kavramları arasındaki fark bir ip yardımıyla (Şekil 14) oluşturulmaya çalışılmıştır. İpin iki ucundan gergin tutulduğu şekil doğruyu, gevşek hali ise eğri çizgiyi gösterdiği ifade edilmiştir. Ayrıca sosyal yaşam ile ilişkilendirilmiş bu durum resimlerle desteklenmiştir. Çizgi kavramı ile beraber eğri yüzey ile düz yüzey arasındaki fark da ifade edilmiştir. Dolayısıyla kavramlar, birbirleri ile ilişkilendirilerek ve somut örnekler verilerek anlatılmaktadır (Zeki, İlk Hendese Dersleri (Birinci Sene), 1332/1914a, s. 5-8).

\subsubsection{Kitapta problem çözme yöntemine yer verilmiş midir?}

Problem çözme yöntemi matematiğin sosyal yaşam ile ilişkilendirilmesini sağlayan kullanışlı bir matematik eğitimi yaklaşımıdır. Bu bölümde Salih Zeki'ye ait 6 adet ders kitabında problem çözme yöntemine yer verilip verilmediği incelenecektir.

Salih Zeki Hendese-i Tecrubiyye isimli kitabında günlük yaşamda karşılaşılabilecek bir durumu probleme dönüştürüp benzerlik konusunu ele almıştır:

“Okulumuzun ilerisine gittiğimizde orda bir ağaç ile yakınından bir de dere geçtiğini görürüz. Derenin karşı tarafina geçip bir çubuk dikmiş olsak, çubuk ile bulunduğumuz yerde bulunan ağaç arasındaki en kısa mesafeyi nasıl ölçebiliriz (Zeki, 1327/1909, s. 17)?”

Bu sorunun çözümünde üçgende benzerlik konusu kullanılmıştır. Benzerlik ihtiyaç olduğu anda şu şekilde tarif edilmiştir:
...şu küçük şekil, üç kenar ve üç açıdan oluşmuş kapalı bir şekildir. İşte böyle 3 kenar ve 3 açıdan ibaret olan kapalı şekle geometride ‘üçgen’ denir. Bundan başka kâğıt üzerine çizdiğimiz küçük şekil; toprak üzerine çizdiğimiz $\mathrm{M}$ ağacı, $\mathrm{G}$ değneği $\mathrm{B}$ çubuğu arasında bulunan $M B G$ üçgenini gösterdiğinden, onun küçük bir suretidir denir. Böyle yapılan bir resim aslına benzerdir. İşte kitaplarda gördüğümüz ev, at, araba resimleri şehirlerde gördüğümüz ev, at, araba resimlerine benzeyecek biçimde yapılmış birer numunedir. Altıncı şekilde gördüğümüz at resmi aslına benzer biçimde yapılmış bir numunedir. $\mathrm{Bu}$ resmin her tarafı dikkatlice ölçülmüş olsa gerçek atın büyüklüğü anlaşılabilir. Örneğin resimde ön ayağı ölçülmüş olsa ve asıl atın ayağından yirmi defa küçük olsa, başı, kuyruğu, kulağı gibi resmin diğer tarafları da atın diğer taraflarından yirmi defa küçük olur. Böyle bir kenarı belli oranda küçültülen resme benzer resim denir. İşte kâğıt üzerine çizmiş olduğumuz $M^{\prime} B^{\prime} G^{\prime}$ üçgeni de gerçekte var olan toprak üzerine çizdiğimiz $M B G$ üçgenine benzerdir (Zeki, 1327/1909, s. 23-24).

Benzerlik konusu, hayatın doğal akışında karşılaşılabilecek problem durumunun içine gizlenmiş ve yine bu olağan akış devam ettirilerek benzerlik konusu yapılandırmacı yaklaşıma uygun olarak sezdirilmeye çalışılmıştır.

Salih Zeki'nin Hendese-i Tecrubiyye kitabında ikizkenar dik üçgenin özelliklerinin gizil olarak anlatıldığı, günlük hayattan bir problem durumu seçilmiştir. Kitapta konuya giriş şu şekildedir:

...Bu derste yakınında bulunduğumuz bir ağacın yüksekliğini ölçeceğiz. Bu ders size bir önceki derslerden daha zor görünse de o kadar zor değildir. Böyle bir ağacın yüksekliğini ölçmek sanki bir ucuna gidilebilen [fakat] diğer ucuna gidilemeyen bir doğrunun uzunluğunu ölçmek demektir. 
Bunda ucuna gidilebilen uç ağacın dibi, gidilemeyen uç da ağacın tepesidir (Zeki, 1327/1909, s. 20-21).

Hendese-i Tecrubiyye kitabının bir sonraki konusunda ise, bir önceki derste benzerlik kavramında izlenen yöntem dik üçgen ve özellikleri için tekrarlanmıştır. İkizkenar dik üçgen oluşturulurken, bir dikdörtgen kâğıt önce kare kâğıda dönüştürülmekte, akabinde köşegen boyunca kesilerek dik üçgen elde edilmektedir. Elde edilen dik üçgenin ikizkenar olma durumu ise kenarlarının birbiri üzerine katlanarak çakıştırılması yöntemiyle test edilmektedir.

\subsubsection{Matematik konuları ile gerçek yaşam arasında ilişkilendirme yapılmış mıdır?}

Günlük yaşamla ilişkilendirilmiş bir matematik dersi, özellikle küçük yaş grubu öğrenciler için çok daha anlaşılır olacaktır. Bu bölümde Salih Zeki’ye ait 6 adet ders kitabında matematik konuları ile gerçek yaşam arasında ilişkilendirmenin yapılıp yapılmadığı analiz edilecektir.

Salih Zeki Ilk Hendese Dersleri, Devre-i Âliye İkinci Sene isimli ders kitabında alan kavramı ile ilgili bir genel tanım verdikten sonra günlük yaşamla şu şekilde ilişkilendirmiştir:

Bir yüzeyi ölçmek demek, karşılaştırmak amacıyla birim olarak (vâhid-i kıyâsî) kabul edilen diğer bir yüzeyin, bu yüzeyde kaç defa bulunduğunu arayıp bulmak demektir. Yüzeyler için umumiyetle kabul edilen birim yüzey, eni bir metre boyu bir metre olan karenin yüzeyidir ki buna metre kare denir. ... İşte bir yüzey, bir metre kareden kaç tanesini alabilirse, o yüzeye o kadar metrekaredir derler. Mesela; "şu beşinci sınıfın dershanesinin alanı 32 metrekaredir" dersek, bu dershanenin zeminine, metrekarelerden yan yana konmak ve aralık bırakmamak şartıyla 32 tanesinin yerleştirilebileceğini anlarız (Zeki ve Hâki, 1332/1914, s. 5).

Bu alan tanımı, daha sonra anlatılacak olan tüm yüzeylerin alan hesabında kullanılacaktır. Dolayısıyla verilen tanımlar arasındaki ilişki kitabın sonuna kadar korunacaktır. Bu anlamda kitapta bir iç tutarlılıktan bahsetmek mümkündür. Alan tanımı verildikten sonra gerçek yaşamdan örnek verilerek matematiksel bilgi ile gerçek yaşam arasında köprü kurulması amaçlanmıştır.

Salih Zeki'nin Ilk Hendese Dersleri, Devre-i Mutavassita İkinci Kitap ismindeki kitabında hacim kavramı günlük yaşamla ilişkilendirilerek şu şekilde tanımlanmıştır:

Bir hacim, boyu, eni ve derinliği veya yüksekliği olan şeydir. Bir odanın içi, bir tuğlanın duvarda kapladığ1 yer, bir fiçının boşluğu hep birer hacimdir. Bir hacmin hem boyu, hem eni, hem derinliği veya yüksekliği vardır. Cisimlerin hacimlerini ölçmek için bilinen bir hacmi 1 olarak kabul etmişlerdir. Bu 1 olarak kabul edilen hacim, eni, boyu, derinliği bir metre olan tavla zarı şeklinde bir "küp" dür. İşte boyu, eni, yüksekliği 1 metre olan bu küpe "metreküp" derler. Bir hacim, bu metreküpten kaç kaç tanesini içine alabiliyorsa o cismin hacmi de o kadar metreküptür derler (Zeki, 1332/1914b, s. 10).

Kitapta hacim kavramının ne olduğuna, hacmin nasıl ölçüldüğüne ve bu işlem için hangi ölçüm araçlarının kullanıldığına değinilmiştir. Ayrıca öğrenci algısına uygun bir şekilde hacim kavramı günlük hayatla ilişkilendirilerek öğrenciye hissettirmeye çalışılmıştır. Bu yerleştirilen hacim kavramı, daha sonra anlatılacak olan tüm cisimlerin hacimlerinde kullanılacaktır. Örneğin prizmaların hacim hesapları için prizma şekli tanıtılırken, dönem öğrencilerinin günlük yaşamlarında sık sık karşılaştıkları soba gibi görsel unsurlar kullanılmıştır. Günlük yaşam ile prizma arasında bir ilişki kurmayı amaçlayan bu yöntemle, öğrencinin zihninde prizma şeklinin somut varlıktan soyut varlığa süzülerek inşa edilmesi amaçlanmaktadır.

Salih Zeki’nin Ilk Hendese Dersleri Birinci Sene isimli ders kitabında paralel doğrular için "bir düzlem üzerinde bulunan ve ne kadar uzatılır ise uzatılsınlar, asla birbirleriyle kesişmeyen doğrulara paraleldirler denir" tanımı verilmiştir. Paralellik kavramı günlük hayattan verilen örnekler ve resimlerle zenginleştirilmiştir. Örneğin Şekil 15'te görüldüğü gibi demir parmaklıklar, müzik notalarının yazıldığ çizgiler, bir taburenin ayakları örnek verilmiştir (Zeki, 1332/1914a, s. 10-11).

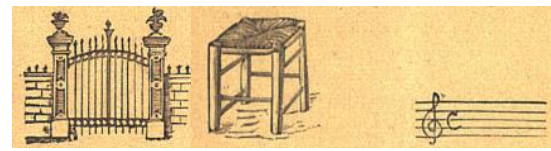

Şekil 15

İlk Hendese Dersleri Birinci Sene isimli ders kitabında doğru kavramının günlük hayatla ilişkilendirilmesi şu şekilde yapılmıştır: 
Hemen her şeyde doğruyla karşılaşmak mümkündür: Mesela ev eşyasından bir dolabın kenarları, etrafı kesilmiş bir kitabın sayfalarının kenarları hep birer doğrudan ibarettir. Doğruyu çizmek: bir doğru çizmek için cetvel denilen alet kullanılır. Cetvel uzunca bir tahtadır ki bir kenarı iki ucundan gerilmiş ince bir ipliğe mutabık gelecek surette düz kesilmiştir. Bununla bir doğru resmetmek yani çizmek için, cetvel kâğıt üzerine yatırılır ve bir kurşun kalem alınarak düz olan kenarı boyunca kaydırılır. Bu halde kalem kâğıt üzerine bir doğru resmeder (Zeki, 1332/1914a, s. 36-37).

Bir doğrunun nasıl inşa edileceği ayrıntılı bir şekilde açıklandıktan sonra, verilen iki nokta arasından doğrunun nasıl çizileceği, çizilmiş bir doğrunun nasıl uzatılacağı ve bir cetvelin düzgün çalışıp çalışmadığının nasıl anlaşılacağı uygulamalı olarak gösterilmiştir. Ayrıca marangozların, duvar ustalarının ve bahçıvanların düz çizgiyi nasıl elde ettikleri ve kullandıkları teçhizatlar izah edilmiştir. Bu sayede doğru kavramının günlük yaşamda izi sürülmüş, kavramın zihinde olgunlaşmasına imkân sağlanmıştır. Gerekli ilişkilendirme sağlandıktan sonra verilen bir doğru parçasının cetvel ile ölçülmesi işlemi yapılmıştır (Zeki, 1332/1914a, s. 37-43). Bu sayede öğrenciler, ilgili matematiksel kavramları yaparak yaşayarak öğrenme firsatı bulmuşlardır.

Ilk Hendese Dersleri Birinci Sene isimli ders kitabında "bir açıya eşit büyüklükte bir açı inşa etme” kazanımı marangozluk mesleği ile ilişkilendirilmiştir. Marangozların, karga burun gönye adını verdikleri bir alet yardımıyla, aynı açı değerine sahip bir açıyı çizmeleri şu şekilde anlatılmıştır:

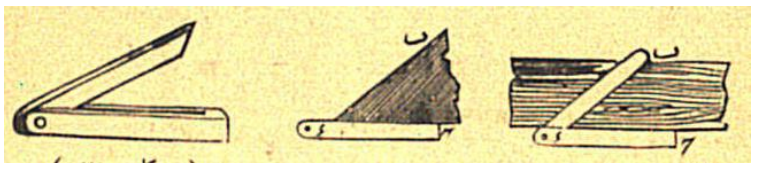

Şekil 16

Marangozlar bir açıya eşit açıyı resmetmek için bir çeşit gönye kullanırlar. Bu gönye iki kollu (Şekil 16) adeta birer uçları birleştirilmiş iki cetvelden ibarettir. Fakat bu birleşen uçlardaki bir çivi etrafında kollar açılıp kapanabilir. Bununla $\widehat{B E C}$ açısına eşit bir açı çizmek için (Şekil 16) kollar açılır ve gönyenin iç köşesi $E$ noktasına ve iç kenarları da $E C, E B$ doğrularına çakıştırılır. Sonra bu kolların açıklığı bozulmaksızın alet kaldırılır ve nereye bu açıyı çizmek gerekiyorsa oraya (mesela bir tahta parçasına) götürülür ve kolların iç kenarları hizasınca birer çizgi çizilir. Hâsıl olan $\widehat{B E C}$ açısı evvelki açının aynı olur (Zeki, 1332/1914a, s. 46-47).

Marangozların işlerinde sıklıkla kullandıkları bu işlemde olduğu gibi Salih Zeki hemen hemen her matematiksel kavramı günlük hayatla ilişkilendirmeye çalışarak matematiği anlamlandırmaya çalışmıştır.

\subsubsection{Kitap, bilginin inşa edilmesinde öğrenciye gerekli malzemeyi ve bilişsel ortamı sağlamış mıdır?}

Yapılandırmacı yaklaşım bilginin ancak zihinde yeniden inşa edilerek tam anlamıyla öğrenilebileceğini iddia eder. Bu bölümde Salih Zeki'nin 6 adet ders kitabının, bilginin inşa edilmesinde gerekli malzemeyi ve bilişsel ortamı sağlayıp sağlamadığı incelenecektir.

Salih Zeki'nin ders kitabında tüm tanımlar bilginin inşa edilmesine uygun olarak açıklanmıştır. Örneğin alan kavramı Ilk Hendese Dersleri, Devre-i Mutavassıta Íkinci Kitap ismindeki kitapta şu şekilde ifade edilmiştir:

Bir yüzeyin alanını ölçmek için diğer bir yüzeyin alanı, karşılaştırılacak birim (vâhid-i kıyâsî) olarak kabul edilir. Bu birim, eni ve boyu birer metre olan bir metre karedir. Buna "metrekare" derler. İşte bir yüzey, bu metrekarelerden kaç tanesini alabilir ise o yüzeyin alanı o kadar metrekaredir derler. Mesela bir odanın döşemesi "10 metrekaredir" denilince bundan şu anlaşılmalıdır: Bu odanın döşemesi 10 tane metrekare kadar bir alana sahiptir (Zeki, 1332/1914b, s. 3-4).

Herhangi bir yüzeyin alanı için verilen bu ifade, öğrencinin zihninde alan kavramına yönelik genel bir bakış açısının kazandırılmasını sağlamıştır. Bu sayede matematiksel kavramlar arasında bir ilişki kurulmuş olacaktır. Genel alan tanımından sonra kitapta özel geometrik yüzeylerin alanları anlatılmıştır.

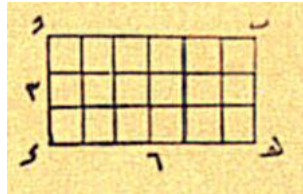

Şekil 17

Bir dikdörtgenin alanı taban uzunluğu ile yüksekliğinin çarpımına eşittir. Mesela (Şekil 17) 6 metre eninde 3 metre boyunda bir dikdörtgen olsa, bu sayıların çarpımı 3x6=18 eder, işte bu dikdörtgenin alanı da 18 metrekare olur. [Bu kural şu şekilde izah edilmektedir] Dikdörtgenin 
boyu 6 metreye ve yüksekliği 3 metreye ayrılsa ve ayrılan noktadan dikdörtgenin kenarlarına paralel doğrular çizilse, 18 tane kare ortaya çıkar ki bu karelerin her biri bir metrekaredir (Zeki, 1332/1914b, s. 4-5).

Salih Zeki'nin kitaplarında alan kavramı genel bir tanımla ifade edildikten sonra, bu tanımın prensiplerine uygun olarak geometrik şekillerin alanlarının nasıl hesaplanacağı anlatılmıştır. Ayrıca Salih Zeki ders kitaplarında dikdörtgen ve karenin alan bağıntısını inşa ettikten sonra paralelkenar şeklinin alanını ele almıştır. Klasik anlatımlarda paralelkenarın alanı en son anlatılan şekillerden biridir. Salih Zeki bilinçli bir şekilde paralelkenarı dikdörtgenden sonra ele almış ve dikdörtgenin alan kavramından paralelkenarın alan kavramına ulaşmıştır. Daha sonra paralelkenarın alan bağıntısından üçgenin alan bağıntısına, üçgenin alan bağıntısından da çokgenlerin ve dairenin alan bağıntılarına ulaştığı görülmektedir. Söz konusu geometrik şekillerin alan bağıntılarının ele alınış sırası inşa faaliyetine uygundur.

Salih Zeki'nin ders kitaplarında dönemin sosyal hayatına uygun resimler konularla ilişkili bir şekilde yer almıştır. Ayrıca geometrik şekillerin de uygun şekilde resmedilmiştir. $\mathrm{Bu}$ durum öğrencinin konuyu somutlaştırması bağlamında inşa faaliyetini destekleyen bir husustur.

Sosyal yaşamdan türetilmiş problem durumları bilginin inşasına pozitif katkı sağlayan noktalardan bir tanesidir. İncelenen ders kitaplarında bu tür problem durumları ile sık sık karşılaşılmaktadır. Ayrıca bölüm sonlarında verilen soruların da bir bölümü günlük hayatın içinden türetilmiştir.

Öğrencinin öğretim faaliyetinin bir parçası olarak sürecin içinde yer alması bilginin inşası için gereklidir. Bu bağlamda teorik olarak ifade edilen geometrik şekillerin gerçek ölçülerde çizimlerinin yaptırılması bilginin özümsenmesine katkı sağlayacaktır. Salih Zeki’nin Illk Hendese Dersleri Birinci Sene isimli ders kitabının ikinci bölümü bu konuya ayrılmıştır (Zeki, 1332/1914a, s. 36-68). Örneğin kitapta şu çizimler yapılmıştır: Doğruyu resmetmek, açıları resmetmek, diklerin resmi, gönye ile dik resmetmek, doğruları, açıları eşit parçalara ayırmak, paralel resmetmek, teğetleri resmetmek, üçgeni resmetmek, dörtgenleri resmetmek.

\subsection{8. Öğrencilere üst düzey düşünme becerileri kazandıracak etkinliklere yer verilmiş midir?}

Bu bölümde Salih Zeki’nin 6 adet ders kitabında öğrencilere üst düzey becerileri kazandıracak etkinliklere yer verilip verilmediği incelenecektir.

Salih Zeki ders kitaplarının bazılarında öğrencilere üst düzey düşünme becerisi kazandıracak etkinlere yer vermiştir. Örneğin, Illk Hendese Dersleri, Devre-i Mutavassita İkinci Kitap ismindeki kitabın üçüncü bölümünde öğrenilen konuların bazı uygulamalarına yer verilmiştir:

Çini denen taşlarla döşemeler, bir şekle eş bir şekil çizmek, bir şeklin alanına eş başka bir şekil çizmek, bir yerden bir yere doğrudan doğruya gidilemeyen iki nokta arasındaki mesafeyi ölçmek, bir ucuna varılamayan doğru parçasının uzunluğunu ölçmek, bir ağacın yüksekliğini ölçmek (Zeki, 1332/1914b, s. 36-52).

$\mathrm{Bu}$ etkinlikler öğrencilerin matematiksel bilgiyi günlük hayata transfer etme becerilerini geliştirecektir.

Salih Zeki’nin Illk Hendese Dersleri, Devre-i Âliye Íkinci Sene isimli ders kitabının üçüncü ve dördüncü bölümlerinde düzgün geometrik cisimlerin hacmi konusu ele alındıktan sonra beşinci bölümünde "düzgün olmayan bir cismin hacmi” etkinliği yapılmıştır. Bu etkinlikle öğrencilerden öğrendikleri hacim kavramının üst düzey bir uygulamasını yapmaları beklenmektedir. Örneğin bir armudun hacminin nasıl hesaplanacağı şu etkinlikle ifade edilmiştir:

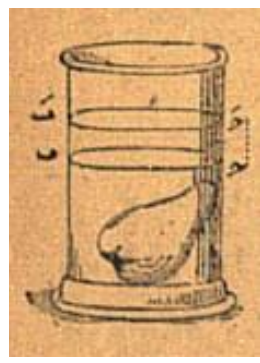

Şekil 18

Evvela Şekil 18'de görülen bir armudun hacmini bulmak için silindir şeklinde içi boş camdan bir kap alırız ve içine bir miktar su doldurarak bu suyun $C B$ seviyesini işaretleriz. Sonra, bunun içine armudu koyarız. Bu halde suyun seviyesi yükseldikten sonra suyun bu defaki $C^{\prime} B^{\prime}$ seviyesini 
işaretleriz. Şu halde suya atılan armudun hacmi, $B C C^{\prime} B^{\prime}$ silindirinin hacmine eşit olduğunu anlamış oluruz.

İşte $B C C^{\prime} B^{\prime}$ silindirinin yüksekliği $\left|B B^{\prime}\right|=0,4$ metre, silindirin ağzının iç tarafından genişliği (çapı) 0,68 metre olsa:

$$
B C C^{\prime} B^{\prime} \text { silindirinin hacmi }=0,34 \times 0,34 \times 3,1416 \times 0,4=0,145267
$$

metreküp olacağından, armudun hacmi 0,145267 metreküp olur.

Illk Hendese Dersleri, Devre-i Mutavassita İkinci Kitap ismindeki kitabın üçüncü bölümünde öğrenilen konuların bazı uygulamalarına yer verilmiştir:

Çini denen taşlarla döşemeler, bir şekle eş bir şekil çizmek, bir şeklin alanına eş başka bir şekil çizmek, bir yerden bir yere doğrudan doğruya gidilemeyen iki nokta arasındaki mesafeyi ölçmek, bir ucuna varılamayan doğru parçasının uzunluğunu ölçmek, bir ağacın yüksekliğini ölçmek (Zeki, 1332/1914b, s. 36-52).

\subsubsection{Diğer disiplinlerle ilişki kurulmus mudur?}

Bu bölümde Salih Zeki'nin 6 adet ders kitabında diğer disiplinlerle ilişki kurulup kurulmadığı tespit edilecektir.

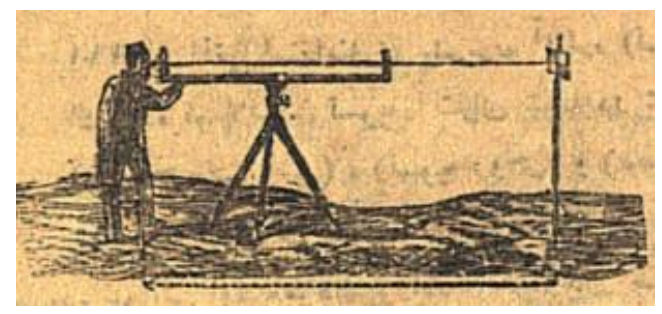

Şekil 19

Salih Zeki'nin Illk Hendese Dersleri, Devre-i Âliye İkinci Sene isimli ders kitabının altıncı bölümünde arazilerin çevre ve alan hesapları, yedinci bölümde de arazilerin sınırlarının hesaplanması konuları ele alınmıştır (Zeki ve Hâki, 1332/1914, s. 57-72). Arazi ölçüm aletleri tanıtıldıktan sonra resimlerle zenginleștirilmiş bir içerikle hesaplamaların nasıl yapılacağı tarif edilmiştir. Bu bağlamda kitapta öğrenilmiş olan geometri bilgisi ile haritacılık arasında bir ilişki kurulmuştur. Diğer ders kitaplarında da arazi ölçümleri ile ilgili örnekler vardır.

Arazi ölçümleri ve haritacılık disiplini ile matematik arasında doğrudan bir ilişki kurularak ders kitaplarına dâhil edilmiştir. Buna karşın ders kitaplarında geometri ile diğer disiplinler arasında doğrudan bir ilişki kurulmamıştır.

\subsubsection{0. İ̧̧erikte grafik, resim, şekil gibi çoklu gösterim araçlarına yer verilmiş midir?}

Bu bölümde Salih Zeki'nin 6 adet ders kitabında yeterli sayıda grafik, resim, şekil gibi çoklu gösterim araçlarına yer verilip verilmediği incelenecektir.

Salih Zeki'nin tüm ders kitaplarında resim ve şekiller geniş bir yer tutmaktadır. Resimler sosyal hayattan alınan fotoğraf karelerinden oluşmaktadır. Bu durum günlük yaşamla matematik arasında bir köprü kurulmasına imkân sağlamıştır. Örneğin küre konusu örneklendirilirken kullanılan resim şu şekildedir (Zeki ve Hâkî, 1334/1915, s. 11):

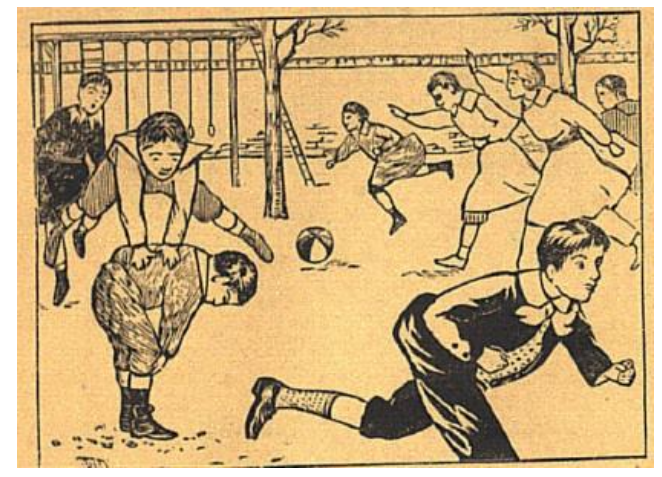

Şekil 20 
Kullanılan geometrik şekiller de konunun anlaşılmasına olanak sağlayacak şekilde hazırlanmıştır. Örneğin $\dot{I} l k$ Hendese Dersleri, Devre-i Âliye İkinci Sene kitabının dikdörtgenin alan hesabı bahsinde şu şekil kullanılmıştır (Zeki ve Hâki, 1332/1914, s. 6):

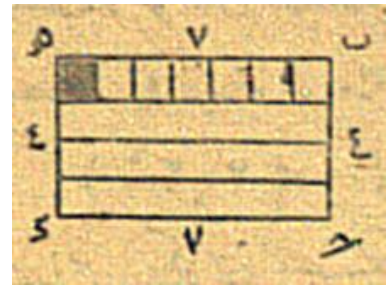

Sekil 21

Salih Zeki Nazarî ve 'Amelî Mücmel Hendese kitabında, kürenin hacmi ile koninin hacmini ilişkilendirerek yaptığı anlatımını şu şekil ile zenginleştirmiştir (Zeki, 1322/1904, s. 215):

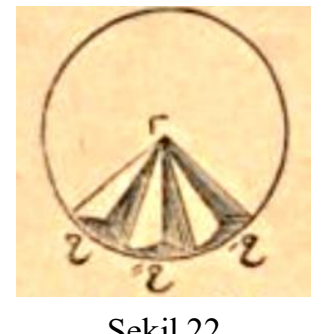

Şekil 22

Salih Zeki ders kitaplarında bu bölümde verilen iki örnekte olduğu gibi çok sayıda resim ve şekil kullanmıştır.

3.1.11. Konu ile ilgili soruların alıştırma problemleri, öğrencinin muhakeme becerisini geliştirecek biçimde organize edilmiş midir?

Bu bölümde Salih Zeki'nin 6 adet ders kitabında yer verilen alıştırma problemlerinin, öğrencinin muhakeme becerisini geliştirecek biçimde organize edilip edilmediği tespit edilecektir.

Salih Zeki'nin ders kitaplarında iki çeşit alıştırma problemi yer almaktadır. Birincisi "Hendese nedir? Örnek veriniz (Zeki ve Hâkî, 1334/1915, s. 11)" türünde direk bilgiyi ölçen alıştırma sorularıdır. Her bölüm sonunda bu türden alıştırmalar yer almaktadır. İkincisi ise "Yüksekliği, tabanının bir kenarına eşit olan bir kare dik prizmanın tüm yüzey alanı 165,68 metrekare olsa yüksekliği ne olur (Zeki ve Hâkî, 1334/1915, s. 83)?” türünde öğrencinin muhakeme becerisi geliştirecek problemlere de yer verilmiştir.

Salih Zeki alıştırma problemlerinde günlük yaşamla ilişkilendirilmiş muhakeme sorularına da yer vermiştir:

Bir minarenin gölgesi 10 metre 25 santimetre olduğu ve 1 metre 10 santimetre yüksekliğinde olan yere dik bir ağacın gölgesinin 35 santimetre olduğu bir yerde minarenin yüksekliği ne olur (Zeki, 1327/1909, s. 42)?

\subsection{Ders Kitaplarında Davranışçı Karakter Taşıyan Örnekler}

Bu bölümde Salih Zeki'nin ders kitaplarında yapılandırmacı karakterle uyuşmayan örneklere yer verilecektir.

Illk Hendese Dersleri kitabında bir dairenin çevresinin nasıl hesaplanacağı şu şekilde anlatılmıştır:

Bir dairenin büyük veya küçük olması, çapının büyük veya küçük olmasına bağlıdır. Yani, bir dairenin çapı kaç kere büyür veya küçülürse, çevresinin uzunluğu dahi o kadar kere büyür veya küçülür. Bir takım hesaplar ve birçok çalışmalar sonucunda, her dairenin çevresinin, kendi çapından 3,1416 sayısı kere büyük olduğu bulunmuştur. Yani bir daire çevresinin ne uzunlukta olduğunun hesaplanabilmesi için önce o dairenin çapı ölçülmeli, daha sonra bulunan sayı 3,1416 sayısı ile çarpılmalıdır. Bu sayı sabittir ve Yunancada " $\pi$ " harfi ile gösterilir ve "pi”" şeklinde okunur.

...Demek ki dairenin çevresi $=$ çap $x \pi$ 'dir (Zeki ve Hâkî, 1334/1915, s. 24).

Yukarıdaki paragrafta dikkat çekici olan nokta, dairenin çevresinin "Bir takım hesaplar ve birçok çalışmalar sonucunda, her dairenin çevresinin, kendi çapından 3,1416 sayısı kere büyük olduğu bulunmuştur” şeklinde belirtilmesidir. Bu yaklaşımda dairenin çevresinin kural olarak öğrenciye verildiği görülmektedir. $\pi$ sayısının ne anlama geldiği anlatılmadığı için, $\pi$ sayısı ile dairenin çevresi arasındaki ilişki havada kalmıştır. Buna rağmen 
yukarıdaki anlatıma muhatap olan bir öğrenci "Yarıçapı 4 metre olan bir dairenin çevresi nedir?" sorusuna doğru cevap verebilecektir. Fakat anlamlı öğrenme gerçekleşmeyecektir.

Salih Zeki İlk Hendese Dersleri Birinci Sene isimli ders kitabının birinci bölümünde çizgi, çember, paralellik, açı, çokgen, üçgen gibi geometrik şekilleri ve bu şekillerin temel elemanlarını tanıtmıştır. Üçgene ait, kenar, köşe, yükseklik gibi kavramları izah ettikten sonra, üçgende açı bahsine değinmiştir. Üçgenin iç açıları toplamının iki dik açıya eşit olduğunu bildirmiş fakat neden böyle olduğu konusunda sorgulamaya gitmemiştir (Zeki, 1332/1914a, s. 27-28).

Söz konusu ders kitaplarının birbirinin devamı olacak şekilde planlandığından, yapılandırmacı anlayışla inşa edilmiş bazı konular, bir sonraki ders kitabında tamamen soyut bir yaklaşımla ifade edilmiştir. Örneğin Salih Zeki'nin Ilk Hendese Dersleri, Devre-i Âliye, Ikinci Sene isimli ders kitabının girişinde, bu kitabın Hendese-i Tecrubiye ve Illk Hendese Dersleri, Devre-i Aliye, Birinci Sene isimli kitapların devamı niteliğinde olduğu vurgulanmıştır (Zeki ve Hâki, 1332/1914, s. 2). Bu kitapta Salih Zeki paralel kenarın alanını dikdörtgenin alanından faydalanarak şu şekilde anlatmaktadır:

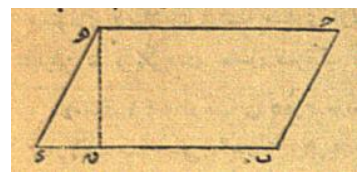

Şekil 23

"Paralelkenarın alanı, tabanı ile tabana ait yüksekliğin çarpımına eşittir. [Bu kural şu şekilde ispatlanabilir] Şekil 23'deki paralelkenar, BE kenarı üzerinde HG yüksekliğinde çizilecek [alan] dikdörtgene eşittir (Zeki ve Hâki, 1332/1914, s. 7).”

Paralelkenarın alanı dikdörtgenin alanı ile ilişkilendirilerek anlatılmasına rağmen, bu kitapta paralelkenarın alanının dikdörtgenin alanına nasıl eşit olduğu açık bir şekilde anlatılmamıştır.

\section{Tartışma ve Sonuç}

Bilimsel bilginin elde edilmesinde ve geliştirilmesinde temel teşkil eden matematik tüm toplumların eğitsel hedeflerinin başında yer almaktadır. Buna karşın, insanlık tarihi boyunca ortaya çıkmış olan topluluklarda matematiği algılayıp öğrenebilenlerin sayısı hep azınlıkta olmuştur. Matematik öğrenmek ve öğretmek ayrıcalık olarak kabul edilmiştir. Günümüzde gelişmiş devletlerin temel bilimlerde diğer toplumlara göre daha ileride olmaları bu durumu örneklendirmektedir. Matematiğin öneminin farkında olan devletler, genç bireylerine matematiği en iyi şekilde öğretme uğraşındadırlar. Dolayısıyla matematik eğitimi sürekli değişim ve gelişim içerisinde olan bir disiplindir. Matematik eğitimcilerinin üzerinde çalıştığı farklı stratejiler bulunmaktadır. Alanyazında kabul gören matematik eğitimi stratejilerinden biri de yapılandırmacı eğitim anlayışıdır. Salih Zeki, bu anlayışın sahip olduğu temel kriterleri içerisinde barındıran geometri ders kitapları hazırladığı tarafımızca tespit edilmiştir. İncelenen kitaplar arasında İlk Hendese Dersleri Birinci Sene isimli ders kitabının önsözünde, ders kitabını okutacak olan matematik öğretmenlerine yönelik, kılavuz mahiyetinde uyarı yazısı kaleme alınmıştır. Bu uyarı yazısında Salih Zeki, “...kitabın içindeki konular ezberlettirilmeksizin çocuklara anlattırılacak" cümlesiyle ezberlemeye karşı olduğunu ve öğrencilerin pasif alıcı olmak yerine aktif olarak derse katılmalarının sağlanmasını; “...birinci bölümün konuları sınıfta, bahçede, kısaca her yerde çocuklara yavaş yavaş gösterilecek ve ikinci bölümün bununla ilgili uygulamaları da hemen beraberce yaptırılacaktır” cümlesiyle öğretilecek olan geometri konularının doğada izlerinin aranmasını ve matematiksel kavramların günlük hayat ile ilişkilendirilmesini; “...çocuklara hiçbir zaman tarifler ezberlettirilmemeli; bilakis şekiller yaptırılarak bu tarifler kendilerine buldurulmalıdır" cümlesiyle tanım ezberletmek yerine, öğrencinin zihninde tanımların yeniden inşasının yapılmasını ve matematiksel bağıntıların öğrenciler tarafından keşfedilmesinin sağlanmasını istemiştir. Salih Zeki'nin bu önsözde ifade ettiği genel çerçeve, yapılandırmacı eğitim anlayışının temel kriterlerini içerisinde barındırmaktadır. Salih Zeki’nin altı ders kitabında da bu kriterlere sadık kaldığ 1 tespit edilmiştir.

Salih Zeki Hendese-i Tecrubiyye kitabında, eğri bir çizginin uzunluğunu ölçmek için somuttan soyuta doğru ilerleyen bir yöntem benimsemiştir. Yapılandırmacı eğitim yaklaşımında konuların birbiriyle ilişki kurularak verilmektedir. Dolayısıyla herhangi bir konunun bir sonraki konuyla ilişkisi olacaksa öğrenci o konuya hazırlanır. "Şüphesiz ki bu küçük doğrular, ne kadar kısa ve ne kadar çok olur ise, onların uzunluklarının toplamı da eğrinin uzunluğuna o kadar yaklaşmış olur" (Zeki, 1327/1909, s. 89-90) cümlesi, içerisinde sonsuz küçükler kavramını barındırmaktadır. İntegral konusu bu yaş grubu öğrencilerin öğrenebileceği bir konu değildir. Ancak Hendese-i Tecrubiyye ders kitabının ortaokul 3. sınıf (bugünkü anlamda) öğrencilerine yönelik hazırlanmış olduğu düşünüldüğünde, sonsuz küçükler mantığı öğrenciye kazandırılarak, sonraki eğitim kurumu olan liseye öğrencilerin matematiksel algılarının hazırlandığı düşünülebilir. 
Salih Zeki Hendese-i Tecrubiyye kitabında benzerlik konusu, hayatın doğal akışında karşılaşılabilecek problem durumunun içine gizlenmiş ve yine bu olağan akış devam ettirilerek benzerlik konusu sezdirilmeye çalışılmıştır. Yapılandırmacı yaklaşımın zıttı olarak düşünebileceğimiz davranışçı yaklaşımla organize edilmiş bir ders akışı şu şekilde olabilirdi: "Bir ABC üçgeni ile DEF üçgeninin benzer olabilmesi için AB kenarı ile DE kenarl, AC kenarl ile DF kenarl, BC kenarl ile EF kenarl arasında sabit bir oran olmasl gerekir." Bilginin öğrenciye bu tarz bir yaklaşımla aktarılması; benzerlik kavramının, mutlak matematiksel doğru olarak düşünüldüğünün ve ezberlenmesi gereken bir kavram olduğunun göstergesi olacaktır. $\mathrm{Bu}$ matematiksel bilgi ancak ezberlenir, özümsenemez.

İk Hendese Dersleri (Birinci Sene) isimli kitapta marangozların işlerinde sıklıkla kullandıkları bir takım işlemler öğrenme ortamına dâhil edilmiştir. Bu durum öğrencinin açı kavramını inşa etme sürecine katkı sağlayacaktır. Kitabın hitap ettiği yaş grubunun 10-12 yaş grubu öğrenciler olması, söz konusu kavramların somut bir şekilde öğrencilere verilmesini zorunlu kılmaktadır. Salih Zeki hemen hemen her matematiksel kavramı günlük hayat ile ilişkilendirmeye çalışarak matematiği anlamlandırmaya çalışmıştır.

Yapılandırmacı anlayışla düzenlenmiş bir matematik eğitiminde disiplinler arası iletişim önemli bir yer tutmaktadır. Arazi ölçümleri ve haritacılık disiplini ile matematik arasında doğrudan bir ilişki kurularak ders kitaplarına dâhil edilmiştir. Söz konusu dönemde ortaokul düzeyinde eğitim veren okullar Osmanlı'nın memur ihtiyacını karşılamaktaydı. Dolayısıyla bir tarım devleti olan Osmanlı’nın arazi ölçümü yapacak devlet memurlarına ihtiyacı vardı. Bu bağlamda haritacılık konusu geometri ders kitaplarının içine yerleştirilmiş olması muhtemeldir. Buna karşın ders kitaplarında geometri ile diğer disiplinler arasında doğrudan bir ilişki kurulmamıştır.

Matematiğin küçük yaş grubu öğrencilerin düşünce dünyalarında şekillenmesine katkı sunan en önemli materyallerden biri de öğrenme ortamının görsel unsurlarla zenginleştirilmesidir. Bu bağlamda Salih Zeki’nin ders kitaplarında çok sayıda resim ve şekil yer almaktadır.

Salih Zeki tüm ders kitaplarında çok sayıda alıştırma problemine yer vermiştir. Bunlardan bir kısmı bilgi düzeyinde iken bir kısmı da öğrencilerin muhakeme becerilerini geliştiren sorulardan oluşmaktadır.

Öğrenme kuramlarından biri olan davranışçı yaklaşım öğrenmeyi, bilişsel süreçlerin yerine, çevrenin davranışlar üzerindeki gözlenebilir etkileriyle açıklar. Bu yaklaşım, öğrenme ürünlerinin gözlenebilir davranışlar olduğu ve bu davranışların değiştirilebileceği varsayımına dayanır. Davranışçılar, kişinin nasıl öğrendiği ile ilgili değil, beynin hangi uyarılara ne gibi tepkiler verdiği ile ilgili çalışmalar yaparlar. Bu yaklaşıma göre öğretilecek konu küçük küçük davranışlara ayrılır ve bu davranışlar öğrenciye sırayla verilir. Davranışçılar öğrenmede kalıcılığın bol tekrar ve alıştırmalar ile sağlanacağını savunurlar (Olkun ve Toluk, 2007). Bu yaklaşıma göre konular alt başlıklar halinde verilir. Öğrencinin konu ile ilgili kural ve formülleri etkili kullanması beklenir. Davranışçı yaklaşımda konu ile ilgili tanım verilir, arkasından örnek çözüm yapılır, daha sonra diğer konuya geçilir. Tanımlar arasında ilişki kurulması gerekmez. Öğrenci daha çok yöntem öğrenir. Bu perspektiften bakıldığında İlk Hendese Dersleri (Birinci Sene) isimli kitapta dairenin çevresinin "Bir takım hesaplar ve birçok çalışmalar sonucunda, her dairenin çevresinin, kendi çapından 3,1416 sayısı kere büyük olduğu bulunmuştur", (Zeki \& Hâkî, 1334/1915, s. 24) şeklinde belirtilmesi dikkat çekmektedir. Bu yaklaşımda dairenin çevresinin kural olarak öğrenciye verildiği görülmektedir. $\pi$ sayısının ne anlama geldiği anlatılmadığı için, $\pi$ sayısı ile dairenin çevresi arasındaki ilişki havada kalmıştır. Buna rağmen yukarıdaki anlatıma muhatap olan bir öğrenci "Yarıçapı 4 metre olan bir dairenin çevresi nedir?" sorusuna doğru cevap verebilecektir. Fakat anlamlı öğrenme gerçekleşmeyecektir. Bunun yerine; Hendese-i Tecrubiyye kitabında ifade edildiği gibi; herhangi bir dairenin çevresinin çapına oranının $\pi$ sayısına karşılık geldiği, dolayısıyla çap ile $\pi$ sayısının çarpımının da dairenin çevresini vereceği açıklanmış olsa, bireyin zihninde dairenin çevresi kavramının inşa edilmesi sağlanmış olacaktır. Dolayısıyla kitabın bu bölümü davranışçı yaklaşıma uygundur. Salih Zeki ders kitaplarında çok az sayıda sadece formül ve bağıntı vermek suretiyle davranışçı bir yaklaşım benimsemiştir.

Salih Zeki'nin matematik felsefesi yaklaşımlarından sezgicilik ekolüne yakın olduğu, Henry Poincaré çevirilerinde ve "Nâmütenâhî" makalesinde ortaya konulmuştur (Ayrıntılı bilgi için bkz. Takıcak, 2016). Matematiği temellendirmek için seçtiği bu ekolün önermelerini, matematik eğitiminde de uygulamıştır. Yapılandırmacı eğitim anlayışı, 20. yüzyıl matematik felsefesi akımlarından Sezgicilik'ten türemiş, temel önermelerini bu akımdan almış bir matematik eğitimi stratejisidir. Dolayısıyla Salih Zeki’nin, hem matematiği açıklamada hem de matematik eğitiminde hedefe yönelik bilinçli bir yol izlediği görülmektedir. Bu durumda Salih Zeki'nin planlı ve programlı bir şekilde, felsefi temeli olan bir matematik eğitimi öngördüğü ve bu öngörü ile Türkiye'nin matematik eğitimine yön vermek istediği ortaya çıkmaktadır.

Günümüzde matematik eğitimi için en etkili yöntemlerden biri olduğu konusunda matematik eğitimcilerinin hemfikir olduğu yapılandırmacı yaklaşımın, Salih Zeki tarafından 20. yüzyılın başında ders kitaplarında kullanılmış olması dikkate değerdir. 19. yüzyılın başından günümüze kadar eğitimde, özellikle de matematik eğitiminde sürekli reformlar yapılmaktadır. Matematik eğitiminde yapılan reformlar daha çok öğretim 
programlarının ve ders kitaplarının yeniden düzenlemesi biçiminde olmuştur. Salih Zeki'nin yazmış olduğu geometri ders kitapları ile bugün matematik eğitiminde kullanılan ders kitaplarının yapılandırmacı karakter taşıdığ 1 görülmektedir. Dolayısıyla bugün matematik eğitiminin kalitesini yükseltmek amacıyla ders kitaplarının ezberden uzak, inşacı bir karakterle donatılması projesinin, Salih Zeki'nin eliyle Cumhuriyet'in ilk yıllarında da

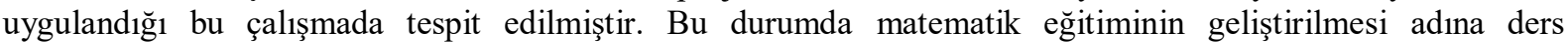
kitaplarının ve öğretim programlarının geliştirilmesinin tek başına yeterli olmadığı görülmektedir. Türkiye'nin matematik eğitiminde ve dolayısıyla matematik üretiminde geri kalmasının nedenleri daha derinlikli bir araştırmayı gerekli kılmaktadır.

\section{5. Öneriler}

Salih Zeki'nin ders kitapları üzerine yapılan bu çalışmaya ek olarak dönemin diğer matematikçilerinin yazmış oldukları ders kitapları benzer biçimde analiz edilebilir. Bu sayede Osmanlı'nın son dönemi ile Cumhuriyet'in ilk yıllarında matematik eğitiminin durumu tüm ayrıntıları ile analiz edilmiş olacaktır.

Türkiye'nin matematik eğitiminde yaşadığı sorunların analizinde, neredeyse tek değişken olarak kabul edilen öğretim programlarının dışında, öğrenci-öğretmen ve çevre şartları gibi muhtemel değişkenler üzerinde de yoğunlaşılmalıdır.

\section{Kaynaklar / References}

Altun, M. (2004). Matematik öğretimi. Bursa: Alfa Yayınları.

Arkün, S. ve Aşkar, P. (2010). Yapılandırmacı öğrenme ortamlarını değerlendirme ölçeğinin geliştirilmesi. Hacettepe Üniversitesi Ĕ̈itim Fakültesi Dergisi, 39, 32-43.

Arslan, M. (2007). Eğitimde yapılandırmacı yaklaşımlar. Ankara Üniversitesi Eğitim Bilimleri Fakültesi Dergisi, 40(1), 41-61.

Baki, A. (2006). Kuramdan uygulamaya matematik eğitimi. Trabzon: Derya Kitabevi.

Brooks, J. G., \& Brooks, M. G. (1999). In search of understanding: The case for constructivist classrooms. Virginia: Association for Supervision and Curriculum Development.

Bukova-Güzel, E. (2008). Yapılandırmacı öğrenme yaklaşımının öğretmen adaylarının matematiksel düşünme süreçlerine olan etkisi. New World Sciences Academi, 3(4), 678-688

Çelik, F. (2006). Türk eğitim sisteminde hedefler ve hedef belirlemede yeni yönelimler. Burdur Eğitim Fakültesi Dergisi, 7(11), 1-15.

Delil, A., ve Güleş, S. (2007). Yeni ilköğretim 6. sınıf matematik programındaki geometri ve ölçme öğrenme alanlarının yapılandırmacı öğrenme yaklaşımı açısından değerlendirilmesi. Uludă Üniversitesi Ĕ̈itim Fakültesi Dergisi, 20(1), 35-48.

Demir, S., ve Şahin, S. (2009). İlköğretim okullarında 1-5. sınıflarda yapılandırmacılık yaklaşıma göre oluşturulan eğitim programlarının uygulanmasında öğretmenlerin karşılaştığı sorunlar. Journal of Qafqaz University, 26(1), 158-171.

Erdem, E., ve Demirel, Ö. (2002). Program geliştirmede yapılandırmacılık yaklaşımı. Hacettepe Üniversitesi Eğitim Fakültesi Dergisi, 23, 81-87.

Ernest, P. (2004). The philosophy of mathematics education. Exeter: Routledge Falmer.

Gömleksiz, M. N., ve Kan, A. Ü. (2007). Yeni ilköğretim programlarının dayandığı temel ilke ve yaklaşımlar. Doğu Anadolu Bölgesi Araştırmalarl, 60-66.

Handal, B. (2009). Matematik pedagojisi ve felsefesi. (S. Ö. Günaydın, Çev.) Illköğretim Online, 8(1), 1-6.

Koç, G., ve Demirel, M. (2004). Davranışçılıktan yapılandırmacılığa: Eğitimde yeni bir paradigma. Hacettepe Üniversitesi Ĕ̈itim Fakültesi Dergisi, 27, 174-180.

MEB. (2009a). Illköğretim matematik dersi 6-8.sınıflar öğretim programı ve klavuzu. Ankara: Milli Ĕ̆itim Bakanlığı Talim Terbiye Kurulu Başkanlığı.

MEB. (2009b, Nisan). Orta öğretim programlarının yenilenme gerekçeleri ve davranışcı yaklaşım ile yapılandırmacı yaklaşım arasındaki farklar. Kasım 28, 2015 tarihinde T.C. Millî Eğitim Bakanlığı Orta Öğretim Genel Müdürlüğü: ogm.meb.gov.tr/belgeler/program_yaklasim.ppt adresinden alındı.

MEB. (2013). Ortaokul matematik dersi (5,6,7 ve 8. sinıflar) öğretim programı. Ankara: Milli Eğitim Bakanlığ Talim Terbiye Kurulu Başkanlığı.

Olkun, S. ve Toluk, Z. (2007). Illköğretimde etkinlik temelli matematik ögrretimi. Ankara: Maya Akademi.

Özgen, K., ve Alkan, H. (2012). Yapılandırmacı öğrenme ortamında öğrenme stilerine uygun geliştirilen etkinliklere yönelik öğrenci görüşlerinin incelenmesi. Dicle Üniversitesi Ziya Gökalp Eğitim Fakültesi Dergisi, 18, 239-258.

Takıcak, M. (2016). Salih Zeki’nin matematik felsefesine bakışı: Nâmütenâhî. Dört Öge, 9, 191-200.

Takıcak, M. (2016). Salih Zeki'nin matematik felsefesi ve matematik eğitimi anlayışı. (Yayınlanmamış Doktora Tezi) Ankara: Ankara Üniversitesi Sosyal Bilimler Enstitüsü. 
Yıldırım, A., ve Şimşek H. (2011). Sosyal bilimlerde nitel araştırma yöntemleri. Ankara: Seçkin Yayıncılık. Zeki, S. (1322/1904). Nazarî ve amelî mücmel hendese. İstanbul: Karabet Matbaas1.

Zeki, S. (1327/1909). Hendese-i tecrubiyye. İstanbul: Karabet Matbaas1.

Zeki, S. (1332/1914a). Illk hendese dersleri (birinci sene). İstanbul: Necm-i İstikbal Matbaas1.

Zeki, S. (1332/1914b). Illk hendese dersleri ikinci sene, devre-i mutavassita dördüncü Sinıf. İstanbul: Necm-i İstikbal Matbaas1.

Zeki, S., ve Hâki, H. (1332/1914). Illk hendese dersleri (ikinci sene). İstanbul: Şirket-i Mürettebiye Matbaası.

Zeki, S., ve Hâkî, H. (1334/1915). Ilk hendese dersleri (birinci Sene). İstanbul: Necm-i İstikbal Matbaas1. 